\title{
Determining the Effects of Imidacloprid on Non-Target Soil Organisms in Hemlock Stands
}

\author{
Braley Burke \\ West Virginia University, brburke@mix.wvu.edu
}

Follow this and additional works at: https://researchrepository.wvu.edu/etd

Part of the Entomology Commons, Environmental Health Commons, Environmental Microbiology and Microbial Ecology Commons, and the Forest Management Commons

\section{Recommended Citation}

Burke, Braley, "Determining the Effects of Imidacloprid on Non-Target Soil Organisms in Hemlock Stands" (2021). Graduate Theses, Dissertations, and Problem Reports. 10190.

https://researchrepository.wvu.edu/etd/10190

This Thesis is protected by copyright and/or related rights. It has been brought to you by the The Research Repository @ WVU with permission from the rights-holder(s). You are free to use this Thesis in any way that is permitted by the copyright and related rights legislation that applies to your use. For other uses you must obtain permission from the rights-holder(s) directly, unless additional rights are indicated by a Creative Commons license in the record and/ or on the work itself. This Thesis has been accepted for inclusion in WVU Graduate Theses, Dissertations, and Problem Reports collection by an authorized administrator of The Research Repository @ WVU. For more information, please contact researchrepository@mail.wvu.edu. 
Graduate Theses, Dissertations, and Problem Reports

2021

Determining the Effects of Imidacloprid on Non-Target Soil Organisms in Hemlock Stands

Braley Burke

Follow this and additional works at: https://researchrepository.wvu.edu/etd

Part of the Entomology Commons, Environmental Health Commons, Environmental Microbiology and Microbial Ecology Commons, and the Forest Management Commons 


\title{
Determining the Effects of Imidacloprid on Non-Target Soil Organisms in Hemlock Stands
}

\author{
Braley Madison Burke \\ Thesis submitted to the Davis College of Agriculture, Natural Resources and Design \\ at West Virginia University \\ in partial fulfillment of the requirements \\ for the degree of \\ Master of Science \\ in \\ Entomology \\ Yong-Lak Park, Ph.D., Chair \\ Petra Wood, Ph.D. \\ Donald Brown, Ph.D. \\ Zachary Freedman, Ph.D. \\ Division of Plant and Soil Sciences \\ Morgantown, West Virginia \\ 2021
}

Keywords: Imidacloprid, Soil, Collembolans, Fungi, Bacteria

Copyright Braley Burke 2021 


\section{Abstract}

\section{Determining the Effects of Imidacloprid on Non-Target Soil Organisms in Hemlock Stands}

\section{Braley Burke}

The hemlock woolly adelgid (HWA), Adelges tsugae Annand (Hemiptera: Adelgidae), is an invasive insect that is causing mortality of eastern hemlock trees, Tsuga canadensis, and Carolina hemlock trees, Tsuga caroliniana, across the eastern United States. To protect these ecologically important tree species, a neonicotinoid insecticide, imidacloprid, is commonly used. Imidacloprid is an effective treatment and can remain effective against HWA for four to six years but long-term ( $\geq$ one year after application) non-target effects of imidacloprid on forest ecosystems are not well-studied. This study examined terrestrial non-target effects of imidacloprid in hemlock stands with different treatment histories to help forest managers better understand the costs and benefits of imidacloprid applications.

To determine the long-term effects of imidacloprid applications on soil collembolan communities, collembolans were systematically sampled, extracted from soil using Berlese funnels, and identified to family, morphospecies, and trophic levels. Overall richness, abundance, and diversity, as well as trophic level (epedaphic, hemiedaphic, and euedaphic) abundance and richness were used to investigate the effects of imidacloprid applications by considering treatment history (control/treatment) and average diameter at breast height (DBH) of treated trees within plots. The collembolan community was not strongly affected by treatment history or DBH of treated trees alone, but epedaphic and hemiedaphic abundance was affected by interactions between the treatment-related variables and soil $\mathrm{pH}$. This study found evidence of long-term effects of imidacloprid applications on the soil collembolan community in hemlock stands when soil $\mathrm{pH}$ interactions were considered.

To determine the long-term effects of imidacloprid applications on soil bacteria and fungi, soil samples were systematically taken to investigate the soil microbial community. The community composition was determined through DNA extraction and classification, and the data were analyzed to determine the effects of imidacloprid on the community. Soil pH had an impact on bacterial and fungal species diversity and richness, and richness was positively associated with imidacloprid treatments. Bacterial and fungal groups most correlated with treatment history were identified using species scores from an RDA.

The results of this study suggest that imidacloprid applications applied at the recommended field rate to control HWA have long term effects on the collembolan community when interactions between treatment-related variables and soil $\mathrm{pH}$ are considered. Abundance 
was greater in treated plots when $\mathrm{pH}$ was lower and greater in control plots when $\mathrm{pH}$ was higher for epedaphic and hemiedaphic communities, and epedaphic abundance decreased as DBH of treated trees increased and $\mathrm{pH}$ was lower. This study also showed that soil $\mathrm{pH}$ influenced the response of soil microorganisms to imidacloprid. Further studies are needed to understand the effects of other important organisms such as mites and nematodes, and we recommend that before-after control-impact (BACI) designs be used to control for environmental variation among sites that could influence responses. 


\section{Acknowledgement}

Firstly, thank you to my advisor, Dr. Park, for guiding me through graduate school with patience and good humor. I appreciate all of the knowledge, advice, stories, and adventures (like visiting South Korea to learn about international entomological research) I have accumulated from being your graduate student.

Thank you to my committee members for helping me understand different aspects of my studies. Thank you, Dr. Freedman, for teaching me about the fascinating, complicated, and emerging science of microorganisms and bioinformatics. Thank you, Dr. Brown, for helping me grasp the intimidating discipline of ecological statistics. You managed to impart more knowledge on the subject than I thought I would be able to grasp. Thank you to Dr. Wood for your insight on ecology and for bringing fresh advice and recommendations for my thesis.

Thank you to the National Park Service for funding this research (PMIS \# 175802 | Task Agreement P16AC00443 | Cooperative Agreement P12AC31164) and thank you to the National Park Service park coordinators for your help with the project: Bryan Wender (2019 - 2020, Chief of Natural Resources, National Park Service) and John Perez (2016 - 2019, Biologist, New River Gorge National River).

Thank you to my lab mates for being excellent companions and helping broaden my knowledge. Thank you to Vicki Kondo for your wealth of knowledge and practical nature. You always know where things are (or should be) and I always look forward to accidentally talking to you for an hour straight instead of doing work. Thank you to Jaewon Kim, my officemate and friend, for always being willing to help me, whether it be teaching me basic Korean or helping me collect samples in the field. Thank you to Craig Larcenaire for making conferences more entertaining and for commiserating with me on graduate school classes. Thank you to Dr. Kyungsan Choi for teaching me about electron microscopy and awing me with your dissecting abilities.

Thank you to Dr. Bernard who taught me about collembolan identification and helped encourage my enthusiasm for collembolans. I would have had a very difficult time finishing this thesis without your help, and besides that, I will always hold a place in my heart for collembolans thanks in part to you. Thank you to Fumin Wang who also helped me complete this thesis. Without your suggestions and guidance on statistics and R I probably would not have finished this thesis during this decade. Thank you to Lenza Paul for helping me find my way to the sites, for taking samples, for measuring environmental variables, and for helping me with the treatment records. You collected a lot of the information for this research and I appreciate the amount of work you put into it. Thank you to Dr. Michelle Hladik (research chemist at the U.S. Geological Survey) who extracted and quantified the imidacloprid from the soil samples and wrote the methods for the imidacloprid extraction sections. Thank you Dr. Terry McManus and Dr. Kang-Mo Ku for imidacloprid extraction help, as well as Tyler Simpson. 
Thank you to my family for helping me get through graduate school. I am very lucky to have such a caring and supportive family always willing to help whether my car breaks down, I need help moving, I need writing or stats advice, or I just need some company. I greatly appreciate all of the love and guidance from my family. Thank you to Andrew, my husband who went through the struggles of graduate school with me and encouraged me with his perseverance and ability to stay up until 3am at the library while I fell asleep on the library couch. Thank you for always being willing to help me, even if it entails driving 2.5 hours to collect soil samples in $90^{\circ} \mathrm{F}$ heat for 4 hours. Thank you to Kari Kindelberger, my best friend and housemate, who had to live with me, not only through graduate school, but also through COVID-19. I appreciate your patience with me, and your help (helping with the dog, taking soil samples with me, and making Figure 3 in Chapter 2). 


\section{Table of Contents}

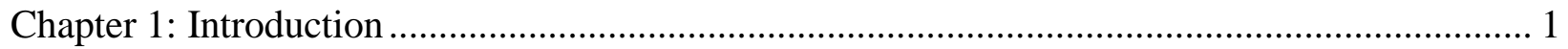

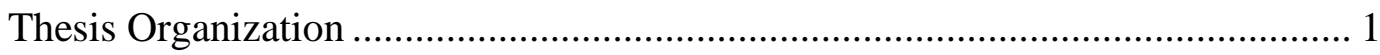

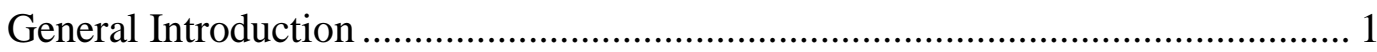

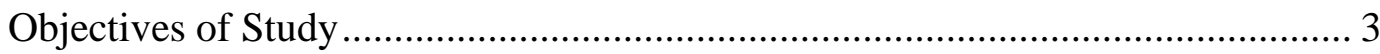

Literature Review................................................................................... 3

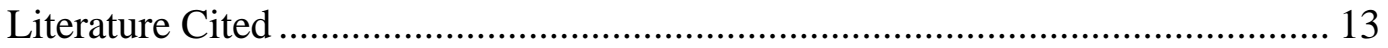

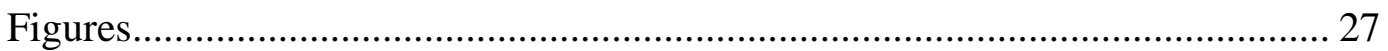

Chapter 2: The long-term effects of imidacloprid on collembolan diversity and abundance in

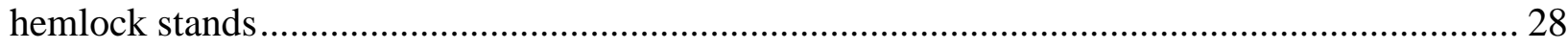

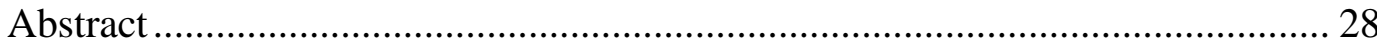

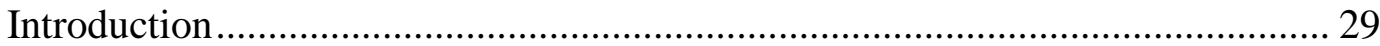

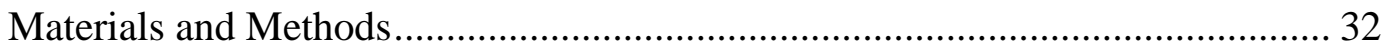

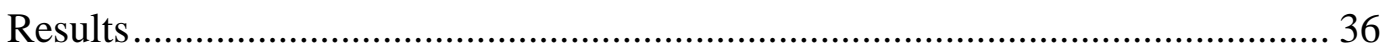

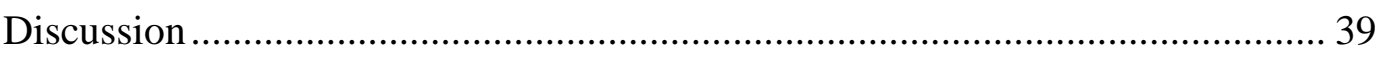

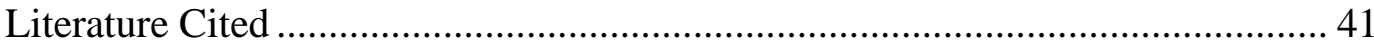

Figures and Tables ....................................................................................... 47

Chapter 3: Long-term effects of imidacloprid on the diversity and abundance of soil fungi and

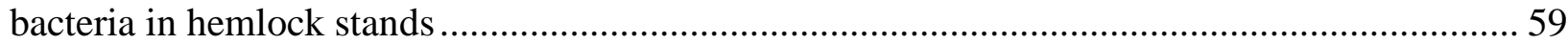

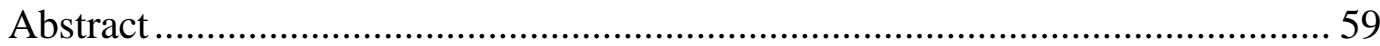

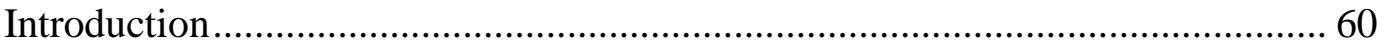

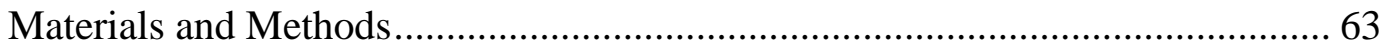

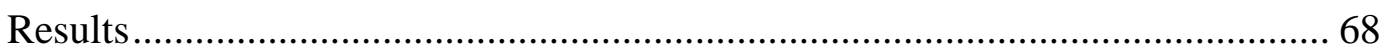

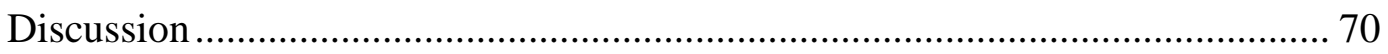

Acknowledgments......................................................................................... 73

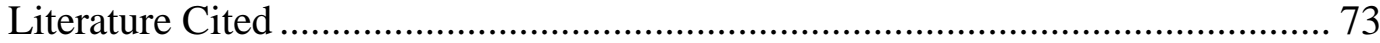

Figures and Tables ........................................................................................ 84

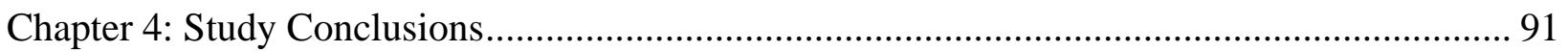




\section{List of Tables}

Chapter 2: The long-term effects of imidacloprid on collembolan diversity and abundance in hemlock stands

Table 1: The 18 treated plots in this study were located in the Gauley River National Recreation Area (GARI) and New River Gorge National River (NERI), and surrounding land in southern West Virginia. The treated plots had varying treatment-related backgrounds. The years since last application (years post application) in treated plots ranged from 1-8 years. Burnwood 2 and Summersville Dam 2 were not treated within the plots, but trees surrounding the plot were treated. Some sites have a range for years since last treatment because they were sampled in 2018 and 2019. Years post application and DBH are not relevant for Summersville Dam 2 and Burnwood 2 because the plots were not treated, but the surrounding area was. Imidacloprid concentration refers to

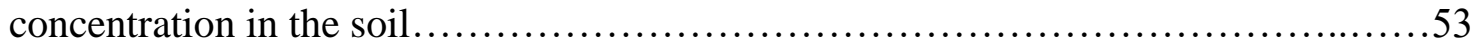

Table 2: Generalized linear mixed models (GLMMs) with a negative binomial distribution were used to determine the effects of imidacloprid on collembolans at the study site located in the Gauley River National Recreation Area (GARI) and New River Gorge National River (NERI), and surrounding land in southern West Virginia. Akaike's Information Criterion corrected for small sample size (AICc) was used for model selection. Overall collembolan diversity, abundance, and morphospecies richness were the response variables for the first group of models. Abundance and richness were also tested for each trophic level (epedaphic, hemiedaphic, and euedaphic). The treatmentrelated variables mean were diameter at breast height $(\mathrm{cm})$ of treated trees within plots $(\mathrm{DBH})$ and whether the plots had a history of being treated or not (Treatment). Soil $\mathrm{pH}$ $(\mathrm{pH})$ and composition (Soil) were explanatory environmental variables. The null model $(\sim 1)$ was used to determine which models were possibly supported

Table 3: Generalized linear mixed models (GLMM) with a negative binomial distribution were used to determine the effects of imidacloprid on collembolan communities in hemlock stands located in the Gauley River National Recreation Area (GARI) and New River Gorge National River (NERI), and surrounding land in southern West Virginia. Community metric (abundance, diversity, and richness) models with a lower AICc score than the null model $(\sim 1)$ and with a treatment-related variable were used to determine the impacts of imidacloprid applications on the collembolan community, along with models with non-treatment-related environmental variables when they can be compared alongside the treatment-related variables. The $85 \%$ confidence intervals (CIs), coefficient $(\beta)$ estimates, and Pseudo R2 for GLMMs values were used to determine the model support. Treatment-related variables included plots with a treatment history vs. control plots (Treatment)and average diameter at breast height of trees treated within the plots (DBH). DBH was used because the amount of imidacloprid applied for hemlock woolly adelgid control is dependent on the $\mathrm{DBH}$ of the tree being treated... .56 
Table 4: The collembolan morphospecies most correlated with imidacloprid applications in hemlock stands located in the Gauley River National Recreation Area (GARI) and New River Gorge National River (NERI), and surrounding land in southern West Virginia were determined. Species scores were extracted from a redundancy analysis (RDA) with treatment history as the explanatory variable Collembolan morphospecies were considered correlated with the treatment-related variables if their species scores were $\geq 0.070$ or $\leq-0.070$. Negative species scores indicate a negative correlation and positive species scores indicate a positive correlation. The abundance of each morphospecies in sites with a history of imidacloprid applications (treat) and with no history of treatments (control) were included. Family was also listed, except for the order Symphypleona which was not identified past order.............................57

Table 5: There were 11 collembolan families (including the order Symphypleona) collected from the paired sites located in the Gauley River National Recreation Area (GARI) and New River Gorge National River (NERI), and surrounding land in southern West Virginia. These samples were collected between spring 2017 - spring 2019. Sampled in the treated plots had a variable treatment history to control hemlock woolly adelgid using the insecticide, imidacloprid. Collembolans in Isotomidae were most abundant, followed by Onychiuridae and Entomobryidae. The total count, mean, and standard error (SE) were calculated for the families in control and treated plots

Chapter 3: Long-term effects of imidacloprid on the diversity and richness of soil fungi and bacteria in hemlock stands

Table 1: The 9 treated plots sampled located in the Gauley River National Recreation Area (GARI) and New River Gorge National River (NERI) in southern West Virginia had varying imidacloprid treatment backgrounds. The years since last application (years post application) in treated plots ranged from 2-8 years. Burnwood 2 and Summersville Dam 2 were not treated within the plots, but trees surrounding the plot were treated. Plots have a range for years since last treatment because they were sampled in 2018 and 2019. Imidacloprid concentration refers to soil concentration........................... 85

Table 2: Samples taken at the Gauley River National Recreation Area (GARI) and New River Gorge National River (NERI) in southern West Virginia were taken to determine the effects of imidacloprid on soil bacteria and fungi. The $\mathrm{pH}$ of the soil within each 20 $\mathrm{m} 2$ plot was taken 12 times throughout 2018. Soil $\mathrm{pH}$ is known to be heterogeneous, so the range of the plots is given to better understand the variation within each

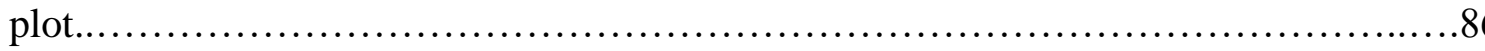

Table 3: Linear mixed models (LMMs) were used to determine the effects of imidacloprid on bacterial and fungal communities at the study sites located in the Gauley River National Recreation Area (GARI) and New River Gorge National River (NERI), and surrounding land in southern West Virginia. Akaike's Information Criterion 
corrected for small sample size (AICc) was used for model selection. Bacterial and fungal diversity and richness were the response variables. The treatment-related variables were mean diameter at breast height of treated trees within plots $(\mathrm{DBH})$, and whether the plots had a history of being treated on not (Treatment). Soil pH, moisture, and composition (Soil) were explanatory environmental variables, and the interaction between $\mathrm{pH}$ and treatment-related variables was included as candidate models. The null model $(\sim 1)$ was used to determine which models were possibly supported.......................... 87

Table 4: Linear mixed models (LMM) were used to determine the effects of imidacloprid on bacterial and fungal communities in hemlock stands located in the Gauley River National Recreation Area (GARI) and New River Gorge National River (NERI), and surrounding land in southern West Virginia. Community richness and Shannon's diversity index (diversity) models with a lower AICc score than the null model ( 1) and with a treatment-related variable were used to determine the impacts of imidacloprid applications on the bacterial and fungal communities, along with models with nontreatment-related environmental variables when they can be compared alongside the treatment-related variables. The $85 \%$ confidence intervals (CIs), coefficient ( $\beta$ ) estimates, and Pseudo R2 for GLMMs values were used to determine the model support. Treatmentrelated variables included plots with a treatment history vs. control plots (Treatment), and average diameter at breast height of trees treated within the plots (DBH). DBH was used because the amount of imidacloprid applied for hemlock woolly adelgid control is dependent on the DBH of the tree being treated..................................... 89

Table 5: The bacterial and fungal taxa (genus or the lowest taxonomic level available) most correlated with imidacloprid applications in hemlock stands located in the Gauley River National Recreation Area (GARI) and New River Gorge National River (NERI), and surrounding land in southern West Virginia were determined. Species scores were extracted from redundancy analysis (RDA) with treatment history as the explanatory variable. Bacterial and fungal taxa were considered correlated with the treatment-related variables if their species scores were $\geq 0.095$ or $\leq-0.095$. Negative scores indicate a negative correlation and species scores indicate a positive correlation. The overall abundance of the bacterial and fungal taxa was also included 


\section{List of Figures}

\section{Chapter 1: Introduction}

Figure 1: The anatomy of a collembolan includes a furcula, the springing organ, the tenaculum which holds the furcula in place when it is not being used, and the collophore which is a tube used for osmoregulation.............................................. 27

Chapter 2: The long-term effects of imidacloprid on collembolan diversity and abundance in hemlock stands

Figure 1: A total of 18 study sites, consisting of paired treated and control plots (36 plots total), were located in the Gauley River National Recreation Area (GARI) and New River Gorge National River (NERI), and surrounding land in southern West Virginia. To the right are the first group of sites sampled spring 2017 and summer 2017. To the left are the second group of sites sampled summer 2018 and spring 2019. Soil arthropod samples were collected to determine the effects of imidacloprid applications on soil collembolans

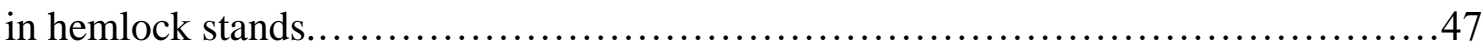

Figure 2: A total of four soil arthropod samples were extracted for each sampling period around $7 \mathrm{~m}$. from the center of the plots located in Gauley River National Recreation Area (GARI) and New River Gorge National River (NERI), and surrounding land in southern West Virginia. Nine paired plots were sampled in spring 2017 and summer 2017. Nine different sites were sampled in summer 2018 and spring 2019. A total of 18 paired sites were sampled................................................... 48

Figure 3: The soil collembolan trophic functionality groups in this study include epedaphic collembolans which live in the leaf litter and top surface of the soil. These collembolans have well-developed legs, furcula, and antennae, as well as pigmentation and many eye units. Hemiedaphic collembolans live in the lower layer of soil and have less developed furcula, legs, and antennae. They also tend to have fewer eyes. Euedaphic collembolans live deep in the soil and usually do not have pigmentation, eyes, or a furcula. They also generally have short legs and antennae.

Figure 4: This flowchart was used to classify soil collembolans into functional groups based on their morphological characteristics. Based on Faber (1991) and Potapov et al. (2016). Atmobiotic collembolans were not present for this study.

Figure 5: Figure 5: Epedaphic collembolan abundance in relation to treated tree diameter at breast height (DBH; top) and treatment history (Control/Treatment; bottom), while accounting for soil $\mathrm{pH}$. For the DBH graph, lines represent expected abundance based on standardized $\mathrm{pH}$ values. For the treatment category graph, abundance data were plotted by standardized $\mathrm{pH}$ value, and a line of best fit was computed for the control and 
treatment plots. The model selection supported an interaction effect with $\mathrm{pH}$ for both

Figure 6: Hemiedaphic collembolan abundance in relation to treatment history (Control/Treatment), while accounting for soil $\mathrm{pH}$. Abundance data were plotted by standardized $\mathrm{pH}$ value, and a line of best fit was computed for the control and treatment plots. The model selection supported an interaction effect with $\mathrm{pH}$ (Table 2)..........53

Chapter 3: Long-term effects of imidacloprid on the diversity and abundance of soil fungi and bacteria in hemlock stands

Figure 1: A total of 9 study sites, consisting of paired treated and control plots, were located in the Gauley River National Recreation Area (GARI) and New River Gorge National River (NERI). The sites were used to determine the long-term effects of imidacloprid applications on soil bacteria and fungi in hemlock stands...............84 


\section{Chapter 1: Introduction}

\section{Thesis Organization}

This thesis is divided into four chapters. Chapter one is an introduction to the topics covered in the research chapters and is a literature review. Chapter two describes the study determining the effects of imidacloprid on the abundance and diversity of soil collembolans in hemlock stands. Chapter three describes the study determining the effects of imidacloprid on soil bacteria and fungi in hemlock stands. Chapter four is a general conclusion of the research chapters.

\section{General Introduction}

The hemlock woolly adelgid (HWA), Adelges tsugae Annand (Hemiptera: Adelgidae), is an invasive insect that feeds on the xylem of eastern hemlock trees (Tsuga canadensis) and Carolina hemlock trees (Tsuga caroliniana) and depletes the trees of nutrients (McClure 1987). This results in the infected trees being more susceptible to stressors and often leads to the tree's death (McClure et al. 2001, Young et al. 1995). The eastern hemlock is an important foundation species which creates habitat space for a variety of wildlife (Ellison et al. 2005).

Throughout the eastern United States imidacloprid, a neonicotinoid insecticide, is used to control and prevent the spread of HWA (Steward and Horner 1994, Silcox 2002) and preserve eastern hemlock trees. Imidacloprid is an effective control method but it has a wide range of target insects (Bayer 2020, Arborjet 2020) causing non-target effects on beneficial insects like bees (Yang et al. 2008). It is also a persistent pesticide with a half-life of up to 1230 days (Baskaran et al. 1999, Sarkar et al. 2001, Graebing and Chib 2004, Singh and Singh 2005) and it can continue to prevent HWA for up to six years after treatment (Silcox et al. 2002, Benton et al. 
2016). After over a decade of use in forest settings, the non-target effects of imidacloprid applications in hemlock stands are unclear.

Soil organisms, including soil arthropods and soil microorganisms, are important for nutrient cycling, decomposition, and plant growth, as well as being important contributors to the food web (Filser 2002, Scheu et al. 2005, Chamberlain et al. 2006). Collembolans are the second most abundant arthropod in most soils, behind mites, and they are important for regulating microbial communities in forest soils and assisting with decomposition (Hanlon and Anderson 1979, Lussenhop 1996). Soil fungi and bacteria are also important terrestrial organisms in forest settings. They are drivers of nutrient cycles (Tiedje 1988, Kowalchuk and Stephen 2001) and important for key ecosystem functioning (van der Heijen et al. 2008), and they have been used as indicators of soil health in other studies (Thomson et al. 2015, Hermans et al. 2017, Sukdeo et al. 2018). The abundance and diversity of these ubiquitous and ecologically important organisms may indicate if there are negative effects from imidacloprid applications caused by long-term exposure. There have been no studies testing the long-term effects of imidacloprid applications to soil collembolans or fungal and bacterial communities in a natural environment.

The study areas for this project in the New River Gorge National River (NERI), Bluestone National Scenic River (BLUE), and Gauley River National Recreation Area (GARI) have over 11,690 acres of hemlock stands (Vanderhorst et al. 2007, Vanderhorst et al. 2008, Vanderhorst et al. 2010) and over 10,000 individual hemlock trees in the study area have been treated with imidacloprid since 2006 (Strickler 2012). To better understand the long-term impact of imidacloprid on non-target collembolans, bacteria, and fungi in a forest setting these soil communities were compared based on treatment sites with a range of treatment histories. 


\section{Objectives of Study}

This study was conducted to determine the long-term non-target effects of imidacloprid applications to hemlock tree stands on select soil organisms. There were two objectives.

Objective I- Determine if diversity, richness, and abundance of soil collembolans are impacted by imidacloprid (Chapter 2).

Objective II- Determine if diversity and richness of soil bacteria and fungi are impacted by imidacloprid (Chapter 3).

\section{Literature Review}

\section{Adelges tsugae and Tsugae canadensis}

HWA, originally from Japan, was introduced in Virginia in the early 1950s (Orwig et al. 2003, Havill et al. 2006). Since its introduction, HWA has spread throughout much of the eastern hemlock's range in 19 states and continues to spread (Ellison et al. 2018). HWA feeds on the xylem of the hemlock tree by inserting their stylet, a part of their sucking mouthpart, at the base of the needles. The feeding leads to reduction in carbohydrate storage, photosynthetic capacity, growth, and a decrease in metabolic activity (Young et al 1995, Gonda-King et al. 2012, Nelson et al. 2014). An infested eastern hemlock tree can die in as few as four years (Young et al. 1995). The hemlock tree decline is altering the composition of eastern United States forests because hemlock trees are being replaced with deciduous trees with thinner canopies. This results in more sunlight reaching the forest floor, warmer water in streams that used to be shaded by hemlocks, more soil moisture, and changes in the flora and fauna that grow in those areas (Spaulding et al. 2010). 
Eastern hemlock is an important tree species that creates a unique niche for many animals. Eastern hemlock supports many birds and mammals, some of these being strongly associated with the hemlock niche as opposed to hardwood niches (Yamasaki et al. 2000, Tingley et al. 2002). When compared with stream communities draining from mixed hardwood forests that likely replace hemlock stands, hemlock forests had significantly different communities (Snyder et al. 2002). The loss of eastern hemlock trees would alter the landscape and remove unique habitats throughout the eastern United States.

\section{Imidacloprid}

Imidacloprid is a very effective pesticide against HWA (Steward and Horner 1994, Cowles et al. 2006). It is a neonicotinoid insecticide that targets the nervous system of insects by binding to the nicotinic receptors of the insect's nervous system which eventually leads to the insect's death (Liu and Casida 1993). This insecticide is applied as a soil drench, soil injection, or trunk injection. The soil applications are more effective against HWA, but trunk injections minimize off-target contamination (Cowles et al. 2006). Imidacloprid is systemic, so it is translocated throughout the tree via the xylem where it can be taken up by insects feeding on it (Elbert et al. 1991). Imidacloprid is also used to control many pests in agriculture and turfgrass include hemipterans (true bugs), thysanopterans (thrips), lepidopterans (butterflies and moths), coleopterans (beetles), hymenopterans (sawflies, bees, and wasps) and dipterans (flies) according to the CoreTect (Bayer 2020) pesticide label and Ima-jet (Arborjet) pesticide label, two of the pesticides used on trees at the treated sites of this study.

In the environment imidacloprid can degrade slowly. Depending on environmental conditions and soil properties, the half-life of imidacloprid in soil can range from 19 days to 1,230 days (Baskaran et al. 1999, Sarkar et al. 2001, Graebing and Chib 2004, Singh and Singh 
2005). Imidacloprid persistence in soil increases with higher soil pH (Sarkar et al. 1999, Sarkar et al. 2001), lower organic matter content (Broznić and Milin 2013), and higher organic matter increases sorption of imidacloprid (Liu et al. 2006). Soil organic matter (SOM) can also influence where the imidacloprid is concentrated. Soil with a low SOM content stores the imidacloprid at the upper $5 \mathrm{~cm}$ of the soil while soils with high SOM is stored deeper in the soil $(\sim 20 \mathrm{~cm})$ (Aseperi et al. 2020). It can remain effective against HWA for four to six years (Silcox et al. 2002, Benton et al. 2016) and can remain in hemlock tissue for up to seven years (Benton et al. 2015).

Using adjacent aquatic study sites to this terrestrial study, Crayton et al. (2020) found imidacloprid in the tissue of aquatic salamanders and benthic macroinvertebrates. They also reported that imidacloprid applications negatively affected salamander body condition and increased their corticosterone levels. The presence of this effective, non-selective, and persistent insecticide in non-target organisms is alarming and requires more investigation on the possible unforeseen consequences of using imidacloprid in natural settings.

\section{Collembolans and Imidacloprid}

Soil arthropods include mites, collembolans, and other taxa such as proturans, pseudoscorpions, and myriapods. The impact of imidacloprid on the soil macro- (measuring 2 $\mathrm{mm}$ to $20 \mathrm{~mm}$ ) and meso-communities (measuring $100 \mu \mathrm{m}$ to $2 \mathrm{~mm}$ ) are important because soildwelling organisms are contributors to forest floor decomposition, as well as the distribution and diversity of the microbial community (Seastedt 1984).

Collembolans, considered members of the meso-community, are known to spread fungal spores through the soil by transporting them on their cuticle or passing them with their feces 
(Williams et al. 1998) and grazing on fungal communities selectively, therefore inhibiting the more preferred fungal species (Klironomos et al. 1992). In this way collembolans can both help and hinder different fungal groups and shape the soil microbial community (Bengtsson et al. 1983, Takeda 1995). In addition to being influencers of the microbial community, collembolans are important contributors in the environment for their roles in translocating carbon from the leaf litter and incorporating it into the soil (Chamberlain et al. 2006) and suppressing fungal plant diseases (Lartey et al. 1994, Sabatini et al. 2001). Collembolans and other soil arthropods are food for many other organisms including reptiles, amphibians, birds, and other arthropods (Hopkin 1997, Walter et al. 1999, Lawrence and Wise. 2000). Collembolans accounted for 24\% of the weight of the consumed prey in salamander stomachs according to Bondi et al. (2019). These ecologically significant arthropods are not only important, but they are also abundant and ubiquitous in soil (Hopkin 1997).

Collembola is a class under the phylum Arthropoda. This class includes three orders: Entomobryomorpha, Poduromorpha, and Symphypleona. They are not insects, but are considered their own class, as their mouthparts are mostly internal, and they have structures that insects do not have, including a collophore (a ventral tube used for osmoregulation), a furcula (the springing organ some collembolans use to propel themselves into the air), and a tenaculum (the small ventral structure that holds the furcula against the collembolan's body when not in use) (Figure 1). They can be classified into atmobiotic, epedaphic, hemiedaphic, and euedaphic based on morphological features, what part of the leaf litter and soil layer they live in, and what they feed on (Faber 1991, Potapov et al. 2016). These functional categories can be useful for assessing if there are more vulnerable groups of collembolans based on where they live and what they feed on. 
Atmobiotic collembolans are found living on plants and the surface of litter. They are large (8-10 mm in length) and often very pigmented. This would include some collembolans in the order Symphypleona, as well as the families Tomoceridae and Entomobryidae.

Epedaphic collembolans are on the surface of the soil, in the leaf litter, or on the surface of logs. These collembolans usually have a pronounced furcula, well developed eyes, and pigmentation. They are the collembolans that feed on the leaf litter and the fungi growing on the forest floor. Major families generally found in this group includes Tomoceridae, Entomobryidae, and Isotomidae, as well as some collembolans from the order Symphypleona.

Hemiedaphic collembolans live in the leaf litter and in the soil. These collembolans often have reduced or absent furcula and fewer ommatidia. They are more likely to crawl through soil, making a furcula less practical. They affect nutrient mobilization by moving organic material from the top layer and incorporating it into the soil (Chamberlain et al. 2006). Major families that are in this category include Neanuridae, Odontellidae, and Hypogastruridae.

Euedaphic collembolans live deep within the soil and often lack eyes, pigmentation and a furcula as they spend their lives in the soil. They feed on plant roots and fungi associated with plant roots. Major families in this group include Onychiuridae, and Tullbergiidae (Faber 1991, Hopkin 1997, Potapov et al. 2016).

\section{Effects of Imidacloprid on Collembolans}

Collembolans are often used in ecotoxicology tests. The Organisation for Economic Cooperation and Development (OECD) has guidelines to standardize the use of two species of collembolans for toxicity tests (OECD 2009). Folsomia candida (Entomobyomorpha:

Isotomidae), the standard collembolan used for testing toxicity, was found to be one of the most 
sensitive species to a variety of pesticides when compared with earthworms and other standard test soil fauna like Enchytraeids and mites (Frampton et al. 2006). Four laboratory studies that tested the toxicity of imidacloprid on F. candida (van Gestel et al. 2017, Mabubu et al. 2017, de Lima e Silva et al. 2017, Ogungbemi et al. 2018) reported that $F$. candida had an $\mathrm{LC}_{50}$ between 0.29 and $1.63 \mathrm{mg} / \mathrm{kg}$ dry soil. The varied results may have been caused by different soils being used in each study. In one of the studies by van Gestel et al. (2017), three generations of $F$. candida had consistently lower abundance from generation to generation when exposed to imidacloprid, though three generations may not have been enough to see a recovery from the $F$. candida abundance. Imidacloprid's effects on multiple soil organisms (de Lima e Silva et al. 2017 were measured for earthworms, enchytraeids, oribatid mites, isopods, and collembolans and found that the collembolan, F. candida, was the most sensitive to imidacloprid ( $\mathrm{LC}_{50}$ of 0.20 to $0.62 \mathrm{mg} / \mathrm{kg}$ dry soil) along with the earthworm, Eisenia andrei $(0.77 \mathrm{mg} / \mathrm{kg}$ dry soil).

Field studies that determined the effects of imidacloprid on forest arthropods are limited. In a study by Knoepp et al. (2012) soil microarthropods were weakly negatively impacted by imidacloprid concentrations, especially in areas with low soil organic matter. A study by Turcotte (2016) measured the difference in the arthropod community in the lower crown of hemlock trees when treating trees with a soil treatment or trunk injection treatment. There was not a significant difference between the arthropod communities in the treated and untreated trees. Another study by Dilling et al. (2009) compared the effects of imidacloprid applications on the hemlock crown arthropod community between soil drench, soil injection, and trunk injection methods. They found that lepidopteran species impacted by the imidacloprid treatments were known to pupate in the soil at the base of trees, which might have reduced their population. 
The effects of imidacloprid on the soil arthropod community were assessed in turfgrass by Peck (2009) which determined that hemipterans, coleopterans (Carabidae and Staphylinidae), thysanopterans, and collembolans (Entomobryomorpha) were significantly impacted by imidacloprid applications. El-Naggar and Zidan (2013) studied the effects of imidacloprid as a seed treatment for cotton on soil arthropods and concluded that mites were negatively impacted while collembolan populations increased. It was speculated that this was caused by a decrease in predatory mites resulting in less predation of collembolans. A field study by Bitzer et al. (2005) tested the effects of seed treatments with imidacloprid in corn fields on the abundance and diversity of collembolans. Compared to the control plots, fields that had treated seeds had a higher abundance of collembolans, but some plots had a lower diversity. Bitzer et al. (2005) concluded that the increased collembolan population was probably caused by a decrease in collembolan predators, as El-Naggar and Zidan (2013) also concluded.

Studies examining the effects of imidacloprid on soil collembolans have not yet considered the long-term effects of collembolans in a forest setting. Many only consider $F$. candida, which is one species out of the entire class. The studies that do consider the entire collembolan community are either agriculturally or turfgrass management oriented, identify collembolans of the phyllosphere, or do not go past collembolan orders in identification.

\section{Soil Bacteria and Fungi, and Imidacloprid}

Soil microorganisms, including soil fungi and bacteria, drive ecosystem functions (van der Heijden 2008) such as nutrient cycling (Tiedje 1988, Paul and Clark 1996) and acquisition (Smith and Read 1997, Richardson et al. 2011), and soil formation (Hobara 2013, Rillig and Mummey 2006). They are also responsible for most organic matter decomposition, which is important for reusing nutrients and maintaining productivity in an ecosystem (Swift 1979). 
Microbial biodiversity has a positive effect on soil productivity, nutrient cycling, regulation of soil biodiversity, and other ecosystem functions according to Balvanera et al. (2006) who analyzed 103 publications measuring biodiversity effects.

Soil microorganisms can be functionally redundant which allows the ecosystem functions to maintain efficiency despite a disturbance that may have destroyed or weakened some microbial species, like an ecological insurance (Yachi and Loreau 1999, Schindler et al. 2015). This is due to the diversity of the environment and allows the ecosystem to function under varying stressors. Because of the functional redundancy of the microbial community, there are questions about the relevance of microbial diversity to gauging an ecosystem's health. Aside from providing the ecosystem with a safety net, microbial diversity is also important because having a high diversity allows microbes to have complementary relationships where they utilize their own niches within a community. They may also have synergistic relationships with one another where multiple species help each other perform well (Saleem et al. 2019). There are positive correlations between soil diversity and increased resistance to environmental stress, as well as ecosystem multifunctionality (Tardy et al. 2013, Wagg et al. 2014) despite functional redundancy. However, decreased microbial diversity can also decrease carbon cycle productivity (Maron et al. 2018). Even though functional redundancy allows the microbial community to have a safeguard against environmental stressors, microbial diversity is still a relevant indicator for ecosystem health and has been used to indicate soil health in multiple studies (Thomson et al. 2015, Hermans et al. 2017, Sukdeo et al. 2018).

When pesticides are applied to an environment, the microbial community can increase, decrease, or stay the same based on how that chemical interacts with the soil microorganisms and their metabolic activity (Singh and Walker 2006, Lo 2010). In addition to affecting abundance, 
the microbial diversity of a treated environment can be affected depending on how the microbes and pesticides interact (Bragança et al. 2019).

\section{Effects of Imidacloprid on Microorganisms}

Multiple studies tested the effects of neonicotinoids, and more specifically, imidacloprid on soil microbial communities. Cycoń et al. (2013) tested the impact of imidacloprid on soil microbes over 56 days using phospholipid fatty analysis (PFLA), a PCR denaturing gradient gel electrophoresis (PCR-DGGE), and analysis of the community level physiological profile (CLPP). They found that imidacloprid applied at the recommended field rate $(1 \mathrm{mg} / \mathrm{kg}$ soil $)$ did not significantly affect the diversity and community structure of the microbial community, while the dose that was ten times more than that of the field rate $(10 \mathrm{mg} / \mathrm{kg}$ soil $)$ significantly altered the microbial community and their metabolic activity.

Cycoń and Piotrowska-Seget (2015a) built upon the previous study. The biochemical and microbial effects of imidacloprid were examined more closely with the same concentrations and same time frame by measured soil respiration, enzyme activity, ammonification and nitrification rates, and culturable bacteria. They found that imidacloprid has a negative impact on soil respiration, some enzyme activities, nitrogen transformation, and number of culturable bacteria. Cycoń and Piotrowska-Seget (2015b) also tested the effects of imidacloprid at the same rate and in the same time frame on ammonia-oxidizing bacteria and archaea and found that there were only transient effects at the field rate, but at $10 \mathrm{~g} / \mathrm{kg}$ of soil, there was a negative effect on ammonia-oxidizing bacteria and a positive effect on ammonia-oxidizing archaea.

Mahapatra et al. (2017) investigated the effects of imidacloprid on the microbial community in rice fields. They used selected media to compare populations of culturable bacteria 
and fungi, compared microbial biomasses, and measured enzyme activity between treatments. They determined that imidacloprid applied at the recommended rate ( $25 \mathrm{~g}$ active ingredient/ha) had an impact on the community, especially the bacterial community, but only for a short period before it recovered. The higher doses (50-250 $\mathrm{g}$ [a.i. $] / \mathrm{ha})$ result in persistent microbial community changes over the 30-day experiment.

Li et al. (2018) tested the effects of wheat seeds coated with imidacloprid and clothianidin, another neonicotinoid insecticide, treatments on bacterial and fungal communities over a growing season using bioinformatics. They found that the soil bacteria and fungi were negatively affected at the beginning of the growing season but recovered and had no lasting effects.

A 112-day study by Yu et al. (2020) investigated the effects of thiamethoxam and dinotefuran (neonicotinoids) on the soil microbial community. They spiked soil with $0.02 \mathrm{mg} / \mathrm{kg}$ of soil, $0.2 \mathrm{mg} / \mathrm{kg}$ of soil, and $2 \mathrm{mg} / \mathrm{kg}$ of soil for each insecticide and measured the soil microbial community and the carbon source utilization periodically. The study concluded that low doses of imidacloprid increased the community diversity while middle and high doses decreased the diversity.

All published studies analyzed the effects of imidacloprid on the soil microbial community in agricultural imidacloprid applications and none of them address the long-term effects of imidacloprid on a natural environment. Imidacloprid applications in hemlock stands involves injecting the soil or tree trunk with high concentrations while agriculture applies imidacloprid with seed coatings or broadcast sprays. This difference most likely results in different effects on soil bacteria and fungi that have yet to be examined. 


\section{Literature Cited}

[OECD] The Organisation for Economic Co-operation and Development. 2009. OECD guidelines for testing chemicals - collembolan reproduction test in soil. Paris, France. 119.

Arborjet. 2020. Ima-Jet: Pesticide Label. https://arborjet.com/product/ima-jet/. Woburn, MA, USA.

Aseperi, A., Busquets, R., Hooda, P., Cheung, P., and J. Barker. 2020. Behaviour of neonicotinoids in contrasting soils. J Environ Manage. 276, 111329.

Balvanera P., Pfisterer A.B., He J.S., Nakashizuka T., Raffaelli D., and B. Schmid. 2006. Quantifying the evidence for biodiversity effects on ecosystem functioning and services. Ecol Lett. 9, 1146-1156

Baskaran, S., Kookana, R. S., and R. Naidu. 1999. Degradation of bifenthrin, chlorpyrifos and imidacloprid in soil and bedding materials at termiticidal application rates. Pestic Sci $55(12), 1222-1228$.

Bayer. 2020. CoreTect: Pesticide Label. https://www.environmentalscience.bayer.us/turf-andornamentals-management/golf-course-management/products/coretect. Cary, NC, USA.

Bengtsson, G., and S. Rundgren. 1983. Respiration and growth of a fungus, Mortierella isabellina, in response to grazing by Onychiurus armatus (Collembola). Soil Biol Biochem. 15, 469-473. 
Benton, E., Grant, J., Webster, R., Cowles, R., Lagalante, A., Saxton, A., Nichols, R., and R. Coots. 2016. Hemlock woolly adelgid (Hemiptera: Adelgidae) abundance and canopy health numerous years after imidacloprid basal drench treatments: implications for management programs. Forest Entomol. 109, 2125-2136.

Benton, E., Grant, J., Webster, R., Nichols, R., Cowles, R., Lagalante, A., and C. Coots. 2015. Assessment of imidacloprid and its metabolites in foliage of eastern hemlock multiple years following treatment for hemlock woolly adelgid, Adelges tsugae (Hemiptera: Adelgidae), in forested conditions. J Econ Entomol. 108(6), 2672-2682.

Bitzer, R.J., Rice, M.E., Pilcher, C.D., Pilcher, C.L., and W.K.F. Lam. 2005. Biodiversity and community structure of epedaphic and euedaphic springtails (Collembola) in transgenic rootworm Bt corn. Environ Entomol. 34(5), 1346-1376.

Bondi, C.A., Beier, C.M.., Fierke, M.K., and P.K. Ducey. 2019. The role of feeding strategy in the tolerance of a terrestrial salamander (Plethodon cinereus) to biogeochemical changes in northern hardwood forests. Can J Zool. 97, 281-293

Bragança, I., Mucha, A. P., Tomasino, M. P., Santos, F., Lemos, P. C., Delerue-Matos, C., and V.F. Domingues. 2019. Deltamethrin impact in a cabbage planted soil: Degradation and effect on microbial community structure. Chemosphere. 220, 1179-1186.

Broznić, D., and C. Milin. 2013. Mathematical prediction of imidacloprid persistence in two Croatian soils with different texture, organic matter content and acidity under laboratory conditions. J Environ Sci Health B. 48(11), 906-918. 
Chamberlain, P. M., McNamara, N. P., Chaplow, J., Stott, A. W., and H.I. Black. 2006. Translocation of surface litter carbon into soil by Collembola. Soil Biol Biochem. 38, 2655-2664.

Cowles, R. S., Montgomery, M. E., and C.J. Cheah. 2006. Activity and residues of imidacloprid applied to soil and tree trunks to control hemlock woolly adelgid (Hemiptera: Adelgidae) in forests. J Econ Entomol. 99, 1258-1267.

Crayton, S. M., Wood, P. B., Brown, D. J., Millikin, A. R., McManus, T. J., Simpson, T. J., Ku, K.M., and Y. L. Park. 2020. Bioaccumulation of the pesticide imidacloprid in stream organisms and sublethal effects on salamanders. Global Ecol Conserv. 24, e01292.

Cycoń, M., and Piotrowska-Seget, Z. 2015a. Biochemical and microbial soil functioning after application of the insecticide imidacloprid. J Environ Sci. 27, 147-158.

Cycoń, M., and Piotrowska-Seget, Z. 2015b. Community structure of ammonia-oxidizing archaea and ammonia-oxidizing bacteria in soil treated with the insecticide imidacloprid. BioMed Res Int. (Article ID 582938)

Cycoń, M., Markowicz, A., Borymski, S., Wójcik, M., and Z. Piotrowska-Seget. 2013. Imidacloprid induces changes in the structure, genetic diversity and catabolic activity of soil microbial communities. J Environ Manag. 131, 55-65.

de Lima e Silva, C., Brennan, N., Brouwer, J., Commandeur, D., Verweij, R., and C. Van Gestel. 2017. Comparative toxicity of imidacloprid and thiacloprid to different species of soil invertebrates. Ecotoxicology. 26, 555-564. 
Dilling, C., Lambdin, P., Grant, J., and R. Rhea. 2009. Community response of insects associated with eastern hemlock to imidacloprid and horticultural oil treatments. Environ Entomol. 38(1), 53-66.

Elbert, A., Becker, B., Hartwig, J., and C. Erdelen. 1991. Imidacloprid: a new systemic insecticide. Pflanzenschutz-Nachrichten Bayer. 44, 113-136.

Ellison, A., Bank, M., Clinton, B. Colburn, E., Elliott, K., Ford, C., Foster, D., Kloeppel, B., Knoepp, J., Lovett, G., Mohan, J., Orwig, D., Rodenhouse, N., Sobczak, W., Stinton, K., Stone, J., Swan, C., Thompson, J., Von Holle, B., and J. Webster. 2005. Loss of foundation species: consequences for the structure and dynamics of forested ecosystems. Front Ecol Environ. 3(9), 479-486

Ellison, A., Orwig, D., Fitzpatrick, M., and E. Preisser. 2018. The past, present, and future of the hemlock woolly adelgid (Adelges tsugae) and its ecological interactions with eastern hemlock (Tsuga canadensis) forests. Insects. 9, 172.

El-Naggar, J. B., and N.E.H. Zidan. 2013. Field evaluation of imidacloprid and thiamethoxam against sucking insects and their side effects on soil fauna. J Plant Protec Res. 53(4), 375387

Faber, J. H. 1991. Functional classification of soil fauna: a new approach. Oikos. 110-117.

Filser, J. 2002. The role of Collembola in carbon and nitrogen cycling in soil. Pedobiologia. 46(3/4), 234. 
Frampton, G. K., Jänsch, S., Scott-Fordsmand, J. J., Römbke, J., and P.J. Van den Brink. 2006. Effects of pesticides on soil invertebrates in laboratory studies: a review and analysis using species sensitivity distributions. Environ Toxicol Chem. 25, 2480-2489.

Gonda-King, L., Radville, L., and E.L. Preisser. 2012. False ring formation in eastern hemlock branches: impacts of hemlock woolly adelgid and elongate hemlock scale. Environ Entomol. 41(3), 523-531.

Graebing, P., and J.S. Chib. 2004. Soil photolysis in a moisture-and temperature-controlled environment. 2. Insecticides. J Agric Food Chem. 52(9), 2606-2614.

Hanlon, R. D. G., and J. M. Anderson. 1979. The effects of Collembola grazing on microbial activity in decomposing leaf litter. Oecologia. 38(1), 93-99.

Havill, N., Montgomery, M., Yu, G., Shiyake, S., and A. Caccone. 2006. Mitochondrial DNA from hemlock woolly adelgid (Hemiptera: Adelgidae) suggests cryptic speciation and pinpoints the source of the introduction to eastern North America. Ann Entomol Soc Am. 99(2), 195-203

Hermans, S. M., Buckley, H. L., Case, B. S., Curran-Cournane, F., Taylor, M., and G. Lear. 2017. Bacteria as emerging indicators of soil condition. Appl Environ Microbiol. 83(1). e02826-16.

Hobara, S., Osono, T., Hirose, D., Noro, K., Hirota, M., and R. Benner. 2014. The roles of microorganisms in litter decomposition and soil formation. Biogeochemistry. 118(1-3), 471-486. 
Hopkin, S. P. 1997. Biology of the springtails: (Insecta: Collembola). Oxford University Press, Oxford, UK.

Klironomos, J.N., Widden, P., and I. Deslandes. 1992. Feeding preferences of the collembolan Folsomia candida in relation to microfungal successions on decaying litter. Soil Biol Biochem. 24, 685-692.

Knoepp, J.D., Vose, J.M., Michael, J.L., and B.C. Reynolds. 2012. Imidacloprid movement in soils and impacts on soil microarthropods in southern Appalachian eastern hemlock stands. J Environ Qual. 41(2), 469-478.

Kowalchuk, G. A., and J.R. Stephen. 2001. Ammonia-oxidizing bacteria: a model for molecular microbial ecology. Annu Rev Microbiol. 55(1), 485-529.

Lartey, R., Curl, E., and C. Peterson. 1994. Interactions of mycophagous collembola and biological control fungi in the suppression of rhizoctonia solani. Soil Biol Biochem. 26, $81-88$

Lawrence, K., and D. Wise. 2000. Spider predation on forest-floor Collembola and evidence for indirect effects on decomposition. Pediologia. 44: 33-39.

Li, Y., An, J., Dang, Z., Lv H., Pan, W., and Z. Gao. 2018. Treating wheat seeds with neonicotinoid insecticides does not harm the rhizosphere microbial community. PloS One. 13(12).

Liu, M. Y., and J.E. Casida. 1993. High affinity binding of $[3 \mathrm{H}]$ imidacloprid in the insect acetylcholine receptor. Pestic Biochem Phys. 46(1), 40-46. 
Liu, W., Zheng, W., Ma, Y., and K.K. Liu. 2006. Sorption and degradation of imidacloprid in soil and water. J Environ Sci Health B. 41(5), 623-634.

Lo, C. C. 2010. Effect of pesticides on soil microbial community. J Environ Sci Health B. 45(5), 348-359.

Lussenhop, J. 1996. Collembola as mediators of microbial symbiont effects upon soybean. Soil Biol Biochem. 28(3), 363-369.

Mabubu, J., Nawaz, M., Cai, W., Zhao, J., He, Y., and H. Hua. 2017. Ecotoxicity of the neonicotinoid insecticides imidacloprid and thiacloprid to the soil-dwelling arthropod Folsomia candida (collembola). J Kans Entomol Soc. 90, 323-333.

Mahapatra, B., Adak, T., Patil, N., Pandi, G., Gowda, G., Jambhulkar, N., and M. Jena. 2017. Imidacloprid application changes microbial dynamics and enzymes in rice soil. Ecotox Environ Safety. 144, 123-130.

Maron, P.A., Sarr, A., Kaisermann, A., Lévêque, J., Mathieu, O., Guigue, J., Karimi, B., Bernard, L., Dequiedt, S., Terrat, S., Chabbi, A., and L. Ranjard. 2018. High microbial diversity promotes soil ecosystem functioning. Appl Environ Microb. 84(9), 113.

McClure, M.S. 1987. Biology and control of hemlock woolly adelgid. Connecticut Agric. Exp. Stat. Bull. 851. New Haven, CT.

McClure, M.S., S.M. Salom, and K.S. Shields. 2001. Hemlock woolly adelgid. U.S. Department of Agriculture, Forest Service, Forest Health Technology Enterprise Team. Morgantown, WV. 
Nelson, L.A., Dillaway, D.N., and L.K. Rieske. 2014. Effect of an exotic herbivore, Adelges tsugae, on photosynthesis of a highly susceptible Tsuga host, with notes on conspecifics. Arthro Plant Interact. 8(1), 9-15.

Ogungbemi, A., and C. van Gestel. 2018. Extrapolation of imidacloprid toxicity between soils by exposing Folsomia candida in soil pore water. Ecotoxicology. 27, 1107-1115.

Orwig, D., Foster, D., and D. Mausel. 2003. Landscape patterns of hemlock decline in New England due to the introduced hemlock woolly adelgid. J Biogeography. 29, 1475-1487.

Paul E.A. and F.E. Clark. 1996. Soil microbiology and biochemistry, $2^{\text {nd }}$ edn. New York, USA: Academic Press.

Peck, D. C. 2009. Long-term effects of imidacloprid on the abundance of surface-and soil-active nontarget fauna in turf. Agric For Entomol. 11(4), 405-419.

Potapov, A.A., Semenina, E.E., Korotkevich, A.Y., Kuznetsova, N.A., and A.V. Tiunov. 2016. Connecting taxonomy and ecology: Trophic niches of collembolans as related to taxonomic identity and life forms. Soil Biol Biochem. 101, 20-31.

Reynolds, W. 2008. Imidacloprid insecticide treatments for hemlock woolly adelgid, Adelges tsugae Annand (Hemiptera: Adelgidae), affect a non-target soil arthropod community surrounding eastern hemlock, Tsuga canadensis (1.) carrier. M.S. Thesis, University of Tennessee, TN.

Richardson, A.E., and R.J. Simpson. 2011. Soil microorganisms mediating phosphorus availability update on microbial phosphorus. Plant Physiol. 156(3), 989-996. 
Rillig, M.C., and Mummey, D.L. 2006. Mycorrhizas and soil structure. New Phytol. 171(1): 41-53.

Sabatini, M.A., and G. Innocenti. 2001. Effects of Collembola on plant-pathogenic fungus interactions in simple experimental systems. Biol Fert Soils. 33: 62-66.

Saleem, M., Hu, J., and A. Jousset. 2019. More than the sum of its parts: microbiome biodiversity as a driver of plant growth and soil health. Annu Rev Ecol Evol S. 50, 6.16.24 .

Sarkar, M.A., Biswas, P.K., Roy, S., Kole, R.K., and A. Chowdhury. 1999. Effect of pH and type of formulation on the persistence of imidacloprid in water. B Environ Contam Toxic. 63(5), 604-609.

Sarkar, M. A., Roy, S., Kole, R. K., and Chowdhury, A. 2001. Persistence and metabolism of imidacloprid in different soils of West Bengal. Pest Manag. Sci. 57(7), 598-602.

Scheu, S., Ruess, L., and M. Bonkowski. 2005. Interactions between microorganisms and soil micro-and mesofauna. In Microorganisms in soils: roles in genesis and functions: 267268. Springer, Berlin, Germany.

Schindler, D.E., Armstrong, J.B., and T.E. Reed. 2015. The portfolio concept in ecology and evolution. Front Ecol Environ. 13(5), 257-263.

Seastedt, T. R. 1984. The role of microarthropods in decomposition and mineralization processes. Annu Rev Entomol. 29(1), 25-46. 
Silcox, C. 2002. Using imidacloprid to control hemlock woolly adelgid. Proceedings Hemlock Woolly Adelgid in the Eastern United States. NJ Agricultural Experiment Station, New Brunswick, NJ, 280-287.

Singh, B.K., and A. Walker. 2006. Microbial degradation of organophosphorus compounds. FEMS Microbiol Rev. 30(3), 428-471.

Singh, J., and D.K. Singh. 2005. Bacterial, azotobacter, actinomycetes, and fungal population in soil after diazinon, imidacloprid, and lindane treatments in groundnut (Arachis hypogaea L.) fields. J Environ Sci Health B. 40(5), 785-800.

Snyder, C.D., Young, J.A., Lemarié, D.P., and D.R. Smith. 2002. Influence of eastern hemlock (Tsuga canadensis) forests on aquatic invertebrate assemblages in headwater streams. Can J Fish Aquat Sci. 59(2), 262-275.

Spaulding, H.L., and L.K. Rieske. 2010. The aftermath of an invasion: structures and composition of Central Appalachian hemlock forests following establishment of the hemlock woolly adelgid, Adelges tsugae. Biol Invas. 12, 3135- 3143

Steward, B., and T.A. Horner. 1994. Control of hemlock woolly adelgid with soil injections using Merit 2F (imidacloprid) and Metasystox-R2 (oxydemeton-methyl), 1993. Arthr Manag Tests. 19(1), 348-348.

Strickler, L. 2012. Hemlock woolly adelgid control project annual report 2012: New River Gorge National River, Gauley River National Recreation Area, and Bluestone National Scenic River. Natural Resources Report NPS/NERI/NRR- 2014/818. National Park Service, Fort Collins, CO. 
Sukdeo, N., Teen, E., Rutherford, P. M., Massicotte, H. B., and K.N. Egger. 2018. Selecting fungal disturbance indicators to compare forest soil profile re-construction regimes. Ecol Indic. 84, 662-682.

Swift, M.J., Heal, O.W., Anderson, J.M. 1979. Decomposition in terrestrial ecosystems. Studies in Ecology, Volume 5. University of California Press. Berkeley, CA.

Smith, S.E. and D.J. Read. 1997. Mycorrhizal Symbiosis, 2nd edn. Academic Press, London, UK.

Takeda, H. 1995. A 5 year study of litter decomposition processes in a Chamaecyparis obtusa Endl Forest Ecol Res. 10, 95-104.

Tardy, V., Mathieu, O., Lévêque, J., Terrat, S., Chabbi, A., Lemanceau, P., Ranjard, L., and P.A. Maron. 2014. Stability of soil microbial structure and activity depends on microbial diversity. Environ Microbiol Rep. 6(2), 173-183.

Thomson, B. C., Tisserant, E., Plassart, P., Uroz, S., Griffiths, R. I., Hannula, S. E., Buee, M., Mougel, C., Ranjard, L., Van Veen, J.A., Martin, F., Bailey, M.J., and

Lemanceau P. 2015. Soil conditions and land use intensification effects on soil microbial communities across a range of European field sites. Soil Biol Biochem. 88, 403-413.

Tiedje, J.M. 1988. Ecology of denitrification and dissimilatory nitrate reduction to ammonium. P. 179-244. In A.J.B. Zehnder (ed), Environmental Microbiology of Anaerobes. John Wiley and Sons, New York, NY. 
Tingley, M. W., Orwig, D. A., Field, R., and G. Motzkin. 2002. Avian response to removal of a forest dominant: consequences of hemlock woolly adelgid infestations. J Biogeogr. 29(10-11), 1505-1516.

Turcotte, R. 2016. Spatial and Temporal Distribution of Imidacloprid within the Crown of Eastern Hemlock. J Insect Sci. 17: 1-7.

Van Der Heijden, M.G., Bardgett, R.D., and N.M. Van Straalen. 2008. The unseen majority: soil microbes as drivers of plant diversity and productivity in terrestrial ecosystems. Ecol Lett. 11(3), 296-310.

van Gestel, C., De Lima e Silva, C., Lam, T., Koekkoek, J., Lamoree, M., and R. Verweij. 2017. Multigeneration toxicity of imidacloprid and thiacloprid to Folsomia candida. Ecotoxicology. 26, 320-328.

Vanderhorst, J.P., B.P. Streets, J. Jeuck, and S.C. Gawler. 2008. Vegetation classification and mapping of Bluestone National Scenic River, West Virginia. Report: NPS/NER/NRTR — 2008/106. U.S. Department of the Interior, National Park Service. Philadelphia, PA.

Vanderhorst, J.P., B.P. Streets, Z. Arcaro, and S.C. Gawler. 2010. Vegetation classification and mapping of Gauley River National Recreation Area, West Virginia. Report: NPS/NER/NRTR - 2010/148. U.S. Department of the Interior, National Park Service. Philadelphia, PA.

Vanderhorst, J.P., J. Jeuck, and S.C. Gawler. 2007. Vegetation classification and mapping of New River Gorge National River, West Virginia. Report: NPS/NER/NRTR - 2007/092. U.S. Department of the Interior, National Park Service. Philadelphia, PA. 
Wagg, C., Bender, S.F., Widmer, F., and M.G. van der Heijden. 2014. Soil biodiversity and soil community composition determine ecosystem multifunctionality. PNAS. 111(14), 5266-5270.

Walter, D.E., and H.C. Proctor. 1999. Mites: ecology, evolution and behaviour. Springer, Dordrecht, Netherlands. 205-206

Williams, R.H., Whipps, J.M., and R.C. Cooke. 1998. Role of soil mesofauna in dispersal of Coniothyrium minitans: mechanisms of transmission. Soil Biol Biochem. 30, 1937-1945.

Yachi, S., and M. Loreau. 1999. Biodiversity and ecosystem productivity in a fluctuating environment: the insurance hypothesis. Proceedings of the National Academy of Sciences. 96(4), 1463-1468.

Yamasaki, M., DeGraaf, R. M., and J.W. Lanier. 2000. Wildlife habitat associations in eastern hemlock-birds, smaller mammals, and forest carnivores. In In: McManus, Katherine A.; Shields, Kathleen S.; Souto, Dennis R., eds. Proceedings: Symposium on sustainable management of hemlock ecosystems in eastern North America. Gen. Tech. Rep. NE-267. Newtown Square, PA: US Department of Agriculture, Forest Service, Northeastern Forest Experiment Station. 267, 135-143

Yang EC, Chuang YC, Chen YL, and L.H. Chang. 2008. Abnormal foraging behavior induced by sublethal dosage of imidacloprid in the honey bee (Hymenoptera: Apidae). J Econ Entomol. 101, 1743-1748.

Young, R., Shields, K., and G. Berlyn. 1995. Hemlock woolly adelgid (Homoptera: Adelgidae): stylet bundle insertion and feeding sites. Ann Entomol Soc Am. 88, 827-835. 
Yu, B., Chen, Z., Lu, X., Huang, Y., Zhou, Y., Zhang, Q., Wang, D., and J. Li. 2020. Effects on soil microbial community after exposure to neonicotinoid insecticides thiamethoxam and dinotefuran. Sci Total Environ. 138328.

Zhang, J., Qin, J., Zhao, C., Liu, C., Xie, H., and S. Liang. 2015. Response of bacteria and fungi in soil microcosm under the presence of pesticide endosulfan. Water Air Soil Pollut. 226(4), 109. 


\section{Figures}

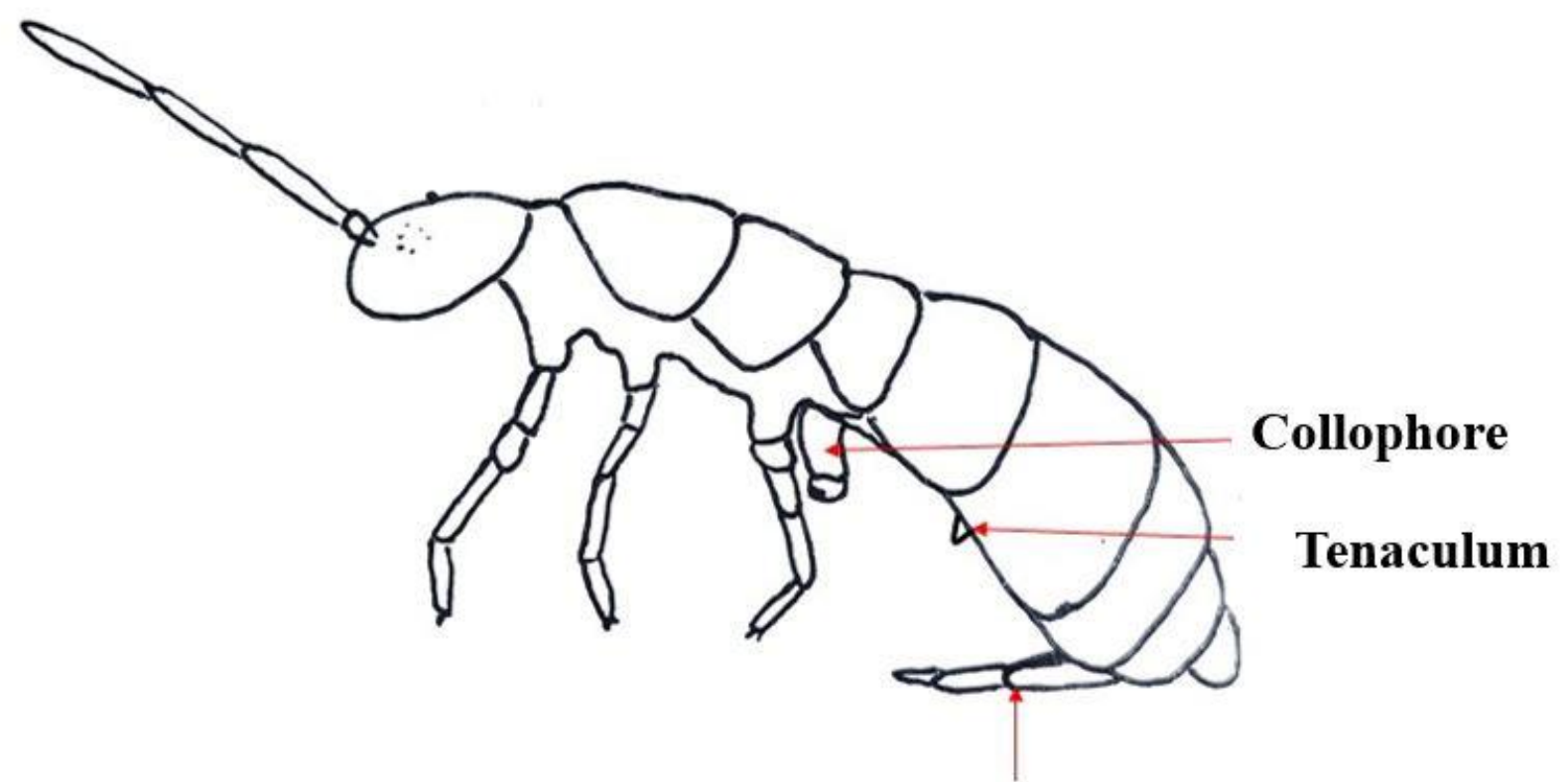

\section{Furcula}

Figure 1: The anatomy of a collembolan includes a furcula, the springing organ, the tenaculum which holds the furcula in place when it is not being used, and the collophore which is a tube used for osmoregulation. 


\title{
Chapter 2: The long-term effects of imidacloprid on collembolan diversity and abundance in hemlock stands
}

\begin{abstract}
Imidacloprid is the most effective way to treat the invasive insect, hemlock woolly adelgid, Adelges tsugae Annand (Hemiptera: Adelgidae), but long-term non-target effects are not well known. This study explored the possible long-term impacts of imidacloprid applications on soil collembolans in the New River Gorge National River (NERI) and Gauley River National Recreation Area (GARI). Samples were collected from 18 paired sites, each with a control and treated plot, with sites sampled twice between spring 2017 and spring 2019. The treated plots had different treatment backgrounds over the past decade. Collembolans were collected at the plots systematically by taking 4 soil samples from each plot, which were combined and extracted using a Berlese funnel. Collembolans were classified into morphospecies, then into trophic functionality groups based on physiological characteristics which relate to their ecological niches. Data were analyzed using generalized linear mixed models (GLMM) and redundancy analysis (RDA). A total of 8,548 collembolans collected were sorted into 10 families (and the order Symphypleona) and 106 morphospecies. Imidacloprid was detected in 11 of the 18 treated plots and ranged from $0.53 \mathrm{ng} / \mathrm{g}$ to $216.53 \mathrm{ng} / \mathrm{g}$. The full collembolan community was not affected by treatment history or diameter at breast height (DBH) of treated trees, but interactions between treatment-related variables and $\mathrm{pH}$ negatively affected epedaphic and hemiedaphic collembolan communities. Abundance was greater in treated plots when $\mathrm{pH}$ was lower and greater in control plots when $\mathrm{pH}$ was higher for epedaphic and hemiedaphic communities, and epedaphic abundance decreased as DBH of treated trees
\end{abstract}


increased and $\mathrm{pH}$ was lower.. This study found evidence of long-term effects of imidacloprid applications on soil collembolan community in hemlock stands when soil $\mathrm{pH}$ interactions are considered.

Keywords: collembolans, forest, imidacloprid

\section{Introduction}

Since its introduction in 1951, hemlock woolly adelgid (Adelges tsugae Annand, HWA) has spread throughout the eastern United States and is causing the decline of eastern hemlock (Tsuga canadensis) trees. Currently the most effective method for controlling this invasive insect is the neonicotinoid insecticide, imidacloprid (Steward and Horner 1994, Cowles et al. 2006). After more than a decade of HWA control using imidacloprid, there are concerns about the longterm non-target effects of this persistent (Silcox et al. 2002, Benton et al. 2016) and non-selective (Bayer 2020, Arborjet 2020) insecticide to the forest system to which it is applied.

Collembolans are a class of soil arthropods that are important regulators of fungal and bacterial communities through selective feeding and spore dispersal (Bengtsson et al. 1983, Takeda 1995). Their influence on soil microbial communities makes them important for nutrient cycling and increasing nutrient availability to plants (Filser 2002). They also contribute to decomposition and translocation of carbon by incorporating leaf litter into the soil (Chamberlain et al. 2006), depending on their ecological niche. Collembolans have specialized niches that can be classified into four categories based on their feeding preferences, the depth of the soil they

live in, and their physiological characteristics (Faber 1991, Potapov et al. 2016). Because of this, their ecological significance can be determined based on their morphological characteristics, 
allowing for a closer examination of the ecological effects of imidacloprid. The four categories are atmobiotic (live on plants and the litter surface), edaphic (live in the upper litter), hemiedaphic (live in a deeper decomposing litter), and euedaphic (live in the upper mineral layer of soil).

Imidacloprid has a half-life of up to 1,230 days in the soil, depending on soil characteristics (Baskaran et al. 1999, Sarkar et al. 2001, Graebing and Chib 2004, Singh and Singh 2005), and can be detected in hemlock tree tissue for up to seven years (Benton et al. 2016). Because of its persistence in the environment, soil collembolans are likely to be exposed to imidacloprid for long periods, but its long-term effects are unknown. The soils in this study have high organic matter content which may cause the imidacloprid to contaminate the lower soil layers more so than the upper layers (Aseperi et al. 2020), which may lead to euedaphic collembolans being the most affected collembolan group.

Studies have investigated the effects of imidacloprid on collembolans, but many have only used Folsomia candida (Family: Isotomidae), a standard collembolan for toxicity tests (van Gestel et al. 2017, Mabubu et al. 2017, de Lima e Silva et al. 2017, Ogungbemi et al. 2018). These studies determined the lethal concentrations that kill $50 \%$ of the collembolan populations $\left(\mathrm{LC}_{50}\right)$ but did not examine the effects that are also relevant to real-world scenarios such as the community level effects and effects of field-level application of imidacloprid. Field studies that test the effects of imidacloprid on collembolan soil communities are limited. Peck (2009) studied the arthropod community response to continual imidacloprid applications to turfgrass over a sixyear period and found that collembolans in the order of Entomobryomorpha were suppressed by imidacloprid applications. A study by El-Naggar and Zidan (2013) found that mites were negatively affected while collembolan abundance increased in a study on the effects of 
imidacloprid treated cotton seeds and foliar sprays in cotton fields. The studies concluded that the increase in collembolan abundance was likely due to a decline in predatory mite abundance. Turcotte et al. (2016) identified and compared arthropods within the lower crown of imidacloprid treated and control eastern hemlocks and found no significant differences, including among arboreal collembolans. The only study examining the effects of imidacloprid on soil collembolan communities in a forest system was Knoepp et al. (2012). They concluded that collembolan abundance had a negative correlation with imidacloprid concentrations at the $20-50 \mathrm{~cm}$ soil depth at high and low elevations, but not within the upper soil concentrations.

This study aimed to determine the long-term ( $\geq 1$-year post imidacloprid application) effects of imidacloprid on soil collembolan communities in forest systems. A recent study by Crayton et al. (2020) used the same study area to determine the long-term effects of imidacloprid on benthic macroinvertebrates and aquatic salamanders. Presence of imidacloprid was found in the benthic macroinvertebrates and salamander tissue, and exposed salamanders had higher corticosterone levels and a lower body condition. Thus, it appears imidacloprid applications in this system are impacting aquatic organisms, but it is unclear what its terrestrial effects are on organisms like collembolans. Using morphospecies and classification of collembolans into functional categories, the long-term effects of imidacloprid on collembolan communities were investigated. The objectives of this study were to determine the effects of imidacloprid applications on collembolan abundance and diversity, and to determine which collembolan morphospecies were most correlated with treatments. Understanding the non-target effects of imidacloprid applications can help forest managers make more informed decisions about using imidacloprid to control HWA. 


\section{Materials and Methods}

\section{Study Sites and Sampling}

The study sites were located on National Park Service land within the New River Gorge National River (NERI), and Gauley River National Recreation Area (GARI) and surrounding land in southern West Virginia (Figure 1). There were 18 sites and 36 plots total, which were sampled twice, once per season. Sites were sampled in the spring and summer of 2017 (first set of 9 paired sites) and in summer of 2018 and spring of 2019 (second 9 paired sites; Fig. 1). Each plot was $20 \mathrm{~m} \times 20 \mathrm{~m}$ to accommodate an adjacent study on the effects of imidacloprid applications on terrestrial salamanders, and the plots were divided into quadrants. Each site was within a hemlock stand and had one treated plot paired with one untreated control plot based on National Park Service records. The treated plots had been treated at different times since the beginning of imidacloprid applications in 2006 (Table 1). National Park Service records were also used to determine the average diameter at breast height $(\mathrm{DBH}$ in $\mathrm{cm})$ of trees that were treated with imidacloprid because the amount of imidacloprid used to treat trees depends on DBH.

\section{Sampling, Extraction, and Identification of Collembolans}

Samples were systematically collected with a 57-mm diameter bulb planter (Van Zyverden, Meridian, Mississippi) to a depth of $10 \mathrm{~cm}$, which is a conservative depth to collect the collembolan community based on other studies (Ponge 2000, Potpov et al. 2016). One sample was taken from the same location (approximately $7 \mathrm{~m}$ from the center of the plot) within each quadrant and the four samples were combined (Figure 2). The samples were placed in plastic bags and stored in a cooler. The same day the soil samples were taken, they were put in 
Berlese funnels to extract the soil collembolans. Samples were left in the Berlese funnels until there were no newly extracted collembolans after nine days. Samples were stored in $95 \%$ ethanol. Once the collembolans were extracted from the Berlese funnels, they were separated from other soil organisms that were also extracted. After that, the collembolans were sorted into families (only order for Symphypleona) and morphospecies, then the morphospecies were categorized into trophic functionality groups (epedaphic, hemiedaphic, and euedaphic) (Faber 1991, Potapov et al. 2016) (Figures 3 and 4). Identification was conducted using a dissecting microscope based on taxonomic keys (Deharveng 2004, Christiansen and Nascimbene 2006). The most common morphospecies were identified to species, or the lowest taxonomic group possible.

\section{Soil pH and Moisture Measurements, and Imidacloprid Extraction}

Mineral soil pH was measured at the center of each plot's quadrant using an EcoSense pH100A meter (YSI, Yellow Springs, Ohio). Soil pH was measured in spring and summer of 2018 on all 36 plots and the average of the quadrants was used as a representation of the respective plot for all samples. Soil texture (loam, sandy loam, gravelly loam, and silt loam) was determined for each plot using Web Soil Survey (USDA 2020).

To measure the concentration of imidacloprid in the soil, soil samples were systematically taken from each plot with a 1.9-cm-diameter soil probe to a depth of $25 \mathrm{~cm}$. The site quadrants were broken into four sub-quadrants and a sample was taken from the center of each, for a total of 16 samples per plot which were mixed and combined into one sample. Soil samples were freeze-dried, homogenized, and $\sim 5 \mathrm{~g}$ dry weight of soil per sample was extracted and combined with $500 \mathrm{mg}$ of carbon and $900 \mathrm{mg}$ of magnesium sulfate. Samples were spiked with the surrogate compound $d_{4}$-imidacloprid (Cambridge Isotope, Andover, MA) and then 
extracted using acetonitrile solvent at $100{ }^{\circ} \mathrm{C}$. The acetonitrile extracts were reduced under nitrogen gas and centrifuged to removed particulates. The final extract was $0.2 \mathrm{~mL}$ in 50:50 acetonitrile:water which was spiked with an internal standard ( $d_{3}$-clothianidin; Cambridge Isotope).

Samples were analyzed using liquid chromatography tandem mass spectrometry (LC-

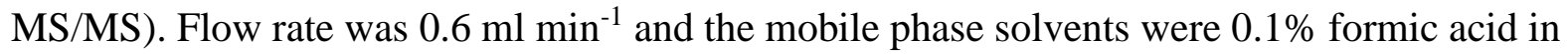
water (A) and acetonitrile (B). The column gradient was 2:98 (A:B) from 0-2 min; 2-4 min increase to 50:50 (A:B), hold for $3 \mathrm{~min}$; 7-7.5 min decrease to 2:98 (A:B), hold for $4.5 \mathrm{~min}$. MS/MS conditions were electrospray (ESI) ionization, positive mode, drying gas temperature at $350^{\circ} \mathrm{C}$, drying gas flow at $10 \mathrm{~L} / \mathrm{min}$, capillary voltage at $4,000 \mathrm{~V}$, and nebulizer at $40 \mathrm{psi}$. Data were collected in the multiple-reaction-monitoring (MRM) mode. The method detection level was $0.2 \mathrm{ng} / \mathrm{g}$ for all compounds. Further details of the LC-MS/MS analytical method can be found elsewhere (Hladik and Calhoun, 2012). Recovery of the surrogate ( $d_{4}$-imidacloprid) was lower (30-70\%) than other soil studies (>70\%), likely due to the organic content of the samples; data were surrogate recovery corrected.

\section{Data Analysis}

The R Statistical program 3.6.3 (R Development Core Team, 2020) was used to conduct statistical analyses. Treatment-related explanatory variables included treatment history (treated with imidacloprid or control plots), and mean DBH of treated trees within plots (Table 1). Concentration of imidacloprid detected in the soil was not used as a predictor candidate due to low recovery rates and presence of high leverage observations. Soil texture and $\mathrm{pH}$ (converted to $\mathrm{H}+$ concentration for analyses) were environmental explanatory variables which were not the focus of the study but used to better understand the complex relationship of the imidacloprid 
treatments and the environment, and how that affected collembolans. Interactions between treatment-related variables and $\mathrm{pH}$ were considered because of the possible influence $\mathrm{pH}$ could have on imidacloprid persistence (Sarkar et al. 1999). The collembolan community was measured using total abundance of individuals, Shannon's Diversity Index for morphospecies, which was calculated in $\mathrm{R}$ using the diversity function in vegan package (Oksanen et al. 2019), and richness (i.e., number of different morphospecies) per plot per sampling.

To determine the effects of imidacloprid on the collembolan community and the trophic functionality groups, generalized linear mixed models (GLMMs) using a negative binomial distribution (Venables and Ripley 2002) were used. These models were created using package lme4 (Bates et al. 2015) with function glmer.nb. Model selection based on Akaike's information criterion corrected for small sample size (AICc) was used to select the most supported models. AICc was calculated using AICcmodavg (Mazerolle 2019). Continuous explanatory variables were standardized prior to analysis (mean $=0, \mathrm{SD}=1)$. This was performed using the decostand function in the vegan package in $\mathrm{R}$ (Oksanen et al. 2019). Candidate models were created with the explanatory variables as fixed effects and site as a random effect. Season was not included in the analysis because it did not influence results based on preliminary analysis. The response variables that were tested included the overall collembolan abundance, richness, and diversity, as well as the richness of morphospecies and overall abundance for each trophic functional group (i.e. epedaphic, hemiedaphic, and euedaphic) (Table 2). For models with more support than the null model, an $85 \%$ confidence interval (CI) was used to determine the strength of individual predictors (Arnold 2010), which were considered strong if the CI did not overlap zero. Pseudo $\mathrm{R}^{2}$ for GLMMs (Nakagawa and Schielzeth 2013, Johnson 2014, Nakagawa et al. 2017) estimated the influence of the fixed variables on the response variables. These were calculated using the 
function r.squaredGLMM from package MuMln and the marginal delta value was reported. The $\beta$ coefficient estimates were used to determine the relationship between the explanatory and response variables (Table 3).

A redundancy analysis (RDA) was used to determine which morphospecies were most correlated with treatment-related variables using the vegan package in R. Before the analysis the morphospecies data was Hellinger transformed to put less weight on rare morphospecies, and response variables occurring in less than $10 \%$ of sites $(<3$ sites) were removed (McCune and Grace 2002). The RDA was performed using a covariance matrix. The response variables for the RDA were the collembolan morphospecies. The explanatory variable was treatment history presence/absence (treatment).To determine the support of the RDA, a global permutation test was performed, and the adjusted $\mathrm{R}^{2}$ value was retrieved from the ordination. The species scores were extracted from the RDA and used to determine groups most influenced by the treatment-

related explanatory variable, treatment. Morphospecies with a species score of $\geq 0.07$ or $\leq-0.07$ were identified as being correlated with treatment history (Table 4). This species score cutoff was created based on the species score range.

\section{Results}

\section{Community Composition}

There was a total of 8,548 collembolans in the samples with 4,457 collected from control plots $(123.8 \pm 33.4 \mathrm{SD})$ and 4,091 collected from plots with previous imidacloprid applications to trees in or directly adjacent to the plots $(113.6 \pm 37.6 \mathrm{SD})$. The collembolans were classified into 10 families, as well as the order Symphypleona, and were categorized into 106 
morphospecies. Most collembolans were euedaphic $(n=5,095,63.9 \%$ of collembolans collected), followed by hemiedaphic ( $\mathrm{n}=2,127,26.7 \%$ of collembolans collected), and epedaphic ( $n=747,9.4 \%$ of collembolans collected). No atmobiotic collembolans were collected. The most common family was Isotomidae $(n=4,694,58.9 \%$ of collembolans collected) followed by Onychiuridae ( $\mathrm{n}=807,10.1 \%$ of collembolans collected) (Table 5). The most common morphospecies was actually multiple species of small, white isotomids: Isotomiella minor, and Folsomia stella $(\mathrm{n}=1,400,17.6 \%$ of collembolans collected) and the second most numerous morphospecies was identified as an undescribed Micrisotoma spp. $(\mathrm{n}=$ $1,049,13.2 \%$ of collembolans collected).

\section{Imidacloprid concentrations and soil variables}

Overall, 11 of 18 treated plots had detectable imidacloprid concentrations at the time of sampling. The concentrations ranged from 0.53 to $216.53 \mathrm{ng} / \mathrm{g}$ dry soil (mean $=17.33 \mathrm{ng} / \mathrm{g}$ dry soil). The different backgrounds of the treated sites, including years since last treatment, concentration, and DBH of treated trees are provided in Table 1. Soil pH ranged from $3.58-$ $5.31(4.23 \pm 0.07 \mathrm{SD})$ for control plots and 3.75 to $5.00(4.19 \pm 0.06 \mathrm{SD})$ for treated plots. Among the 36 plots, $61 \%$ had gravelly loam for soil texture, $22 \%$ had sandy loam, $8 \%$ had silt loam, and $8 \%$ had loam.

\section{Collembolan Community Response}

For the full collembolan community, the null, soil texture, and $\mathrm{pH}$ models were the most supported models for diversity, abundance, and richness, respectively (Table 2). None of the treatment models were more supported than the null model. When the data were analyzed by trophic group, several treatment models were more supported than the null model (Table 2, Table 
3). For epedaphic abundance, treatment $\mathrm{x} \mathrm{pH}$ was the most supported model, with $\mathrm{DBH} \times \mathrm{pH}$ also receiving more support than the null model. The interaction effect CI did not overlap 0 for either model. For the treatment $\mathrm{x} \mathrm{pH}$ model, abundance was greater in treated plots when $\mathrm{pH}$ was low, and greater in control plots when $\mathrm{pH}$ was high (Figure 5). For the DBH x pH model, abundance decreased as treated tree DBH increased (Figure 5). For hemiedaphic abundance, four models received more support than the null model, with treatment $\mathrm{x} \mathrm{pH}$ being the most supported treatment model. The interaction effect CI did not overlap 0 for this model. Similar to the epedaphic trophic group, abundance was greater in treated plots when $\mathrm{pH}$ was low, and greater in control plots when $\mathrm{pH}$ was high (Figure 6). For euedaphic abundance, only soil texture received more support than the null model. For epedaphic richness, the null model received the highest support. For hemiedaphic richness, the DBH model was more supported than the null model. The CI for this model did not overlap 0 , and it estimated a positive relationship between hemiedaphic richness and treated tree DBH (Table 3). For euedaphic richness, the DBH and treatment models were more supported than the null model. The coefficient CI did not overlap 0 for either model, and both models estimated a positive relationship between euedaphic richness and the treatment variables. Pseudo $R^{2}$ values for supported treatment models ranged from $0.028-0.119$ (Table 3).

One RDA was created for morphospecies analysis. Treatment history was the explanatory variable and was not globally significant $\left(p=0.560\right.$, adj. $\left.R^{2}=-0.002\right)$. The species scores from the RDA were extracted to examine which morphospecies were most correlated with the treatment history. There were two morphospecies in the family Hypogastruridae that were positively correlated with treatment history and three morphospecies in the order Symphypleona that were negatively correlated with treatment history (Table 4). Counts for each family in treated and control plots are shown in Table 5. 


\section{Discussion}

The most common collembolan family was Isotomidae which made up more than half of all collembolans collected $(n=4,694,58.9 \%$ of collembolans collected), followed by Onychiuridae ( $\mathrm{n}=807,10.1 \%$ of collembolans collected). Onychiuridae and Isotomidae were also the most abundant families in a study located in an oak-hickory forest along the Ohio River valley (34\% and 31\%, respectively) (Kuperman et al. 2002). Members of Onychiuridae are generally euedaphic, while members of Isotomidae are variable and can be epedaphic, hemiedaphic, or euedaphic occasionally. A study done in the Pennsylvania Laurel Highlands mainly collected collembolans from families Hypogastruridae (36.6\%), Tomoceridae (32.3\%) and Isotomidae (21.0\%) by using pitfall traps (Perry et al. 2018). All of these families tend to be epedaphic or hemiedaphic most likely because pitfall traps were used for sampling. Isotomidae is a widespread family of collembolans in the order Entomobryomorpha which can be found throughout the world. They are identified by their evenly proportioned body segments (Hopkin 1997). Onychiuridae is a family in the order Poduromorpha that generally lacks eyes, pigmentation, or furcula. They are known for having "pseudocelli" or pores which excrete defensive fluids for protection (Hopkin 1997).

Most collembolans were euedaphic ( $n=5,095,63.9 \%$ of collembolans collected) which live in the upper mineral layers in the soil. It was hypothesized that this group would be most affected by treatments because of the high soil organic matter (SOM) at the sites. The high SOM would lead to imidacloprid leaching into lower soil layers instead of staying near the surface (Aseperi et al. 2020). The euedaphic collembolan richness had a positive correlation with whether the plots had been treated in the past and the mean DBH of treated trees within the plots, though the explanatory power of the treatment variable was low in both cases $\left(\mathrm{GLMM} \mathrm{R}^{2}=\right.$ 
0.039 and 0.047 , respectively). Based on the results, euedaphic and hemiedaphic collembolans had long-term effects in abundance when considering interactions between treatment-related variables and $\mathrm{pH}$. This indicates that treatments could decrease or increase community abundance depending on the soil $\mathrm{pH}$, with lower soil $\mathrm{pH}$ resulting in less abundance in treated plots.

All collembolans that were negatively correlated with treatment history were in the order Symphypleona and were epedaphic, but the epedaphic collembolans were not collectively affected by treatments. No atmobiotic collembolans were collected from the samples, as they generally do not reside within the soil and are found on top of leaf litter or on plants (Potapov et al. 2016). Turcotte (2016) examined the aboveground effects of imidacloprid applications in hemlock stands and did not find differences in the arthropod communities between treated and untreated trees. When considered alongside the Crayton et al. study (2020), which sampled the same study area as this study, imidacloprid cannot be considered harmless for non-target organisms. Their study found that aquatic salamanders and benthic macroinvertebrates had bioaccumulation of imidacloprid in their tissue, and salamanders exposed to imidacloprid had significantly higher corticosterone levels and lower body condition than those that were not.

This study evaluated the effects of imidacloprid using morphospecies to determine diversity. Future studies could evaluate the effects of imidacloprid on soil collembolans by studying sites over time. This study found evidence of long-term effects of imidacloprid applications on soil collembolan community in hemlock stands when soil $\mathrm{pH}$ interactions are considered. 


\section{Literature Cited}

Arborjet. 2020. Ima-Jet: Pesticide Label. https://arborjet.com/product/ima-jet/. Woburn, MA, USA.

Arnold, T.W. 2010. Uninformative parameters and model selection using Akaike's Information Criterion. J Wildl Manag 74(6), 1175-1178.

Aseperi, A.K., Busquets, R., Hooda, P.S., Cheung, P.C., and J. Barker. 2020. Behaviour of neonicotinoids in contrasting soils. J Environ Manage 276, 111329.

Baskaran, S., Kookana, R.S., and Naidu, R. 1999. Degradation of bifenthrin, chlorpyrifos and imidacloprid in soil and bedding materials at termiticidal application rates. Pestic Sci $55(12), 1222-1228$.

Bates D, Mächler M, Bolker B, and S. Walker. 2015. Fitting Linear Mixed-Effects Models Using lme4. J Stat Softw 67(1), 1-48.

Bayer. 2020. CoreTect: Pesticide Label. https://www.environmentalscience.bayer.us/turf-andornamentals-management/golf-course-management/products/coretect. Cary, NC, USA.

Bengtsson, G., and S. Rundgren. 1983. Respiration and growth of a fungus, Mortierella isabellina, in response to grazing by Onychiurus armatus (Collembola). Soil Biol Biochem 15: 469-473.

Benton, E., Grant, J., Webster, R., Cowles, R., Lagalante, A., Saxton, A., Nichols, R., and R. Coots. 2016. Hemlock woolly adelgid (Hemiptera: Adelgidae) abundance and canopy health numerous years after imidacloprid basal drench treatments: implications for management programs. Forest Entomol 109: 2125-2136. 
Chamberlain, P.M., McNamara, N.P., Chaplow, J., Stott, A.W., and H.I. Black. 2006. Translocation of surface litter carbon into soil by Collembola. Soil Biol Biochem 38: 2655-2664.

Christiansen, K.A. and P. Nascimbene. 2006. Collembola (Arthropoda, Hexapoda) from the mid Cretaceous of Myanmar (Burma)., Cretaceous Res 27, 318-363.

Cowles, R.S., Montgomery, M.E., and C.J. Cheah. 2006. Activity and residues of imidacloprid applied to soil and tree trunks to control hemlock woolly adelgid (Hemiptera: Adelgidae) in forests. J Econ Entomol 99: 1258-1267.

Crayton, S.M., Wood, P.B., Brown, D.J., Millikin, A.R., McManus, T.J., Simpson, T.J., Ku, K.M., and Y.L. Park. 2020. Bioaccumulation of the pesticide imidacloprid in stream organisms and sublethal effects on salamanders. Global Ecol Conserv 24, e01292.

de Lima e Silva, C., Brennan, N., Brouwer, J., Commandeur, D., Verweij, R., and C. Van Gestel. 2017. Comparative toxicity of imidacloprid and thiacloprid to different species of soil invertebrates. Ecotoxicology 26: 555-564.

Deharveng, L. 2004. Recent advances in Collembola systematics., 6th International Seminar on Apterygota, Siena, Italy, 2002, Pedobiologia 48, 415-433.

El-Naggar, J. B., and Zidan, N.E.H.A. 2013. Field evaluation of imidacloprid and thiamethoxam against sucking insects and their side effects on soil fauna. J Plant Protec Res 53(4): 375-387

Faber, J.H. 1991. Functional classification of soil fauna: a new approach. Oikos 110-117. 
Filser, J. 2002. The role of Collembola in carbon and nitrogen cycling in soil. Pedobiologia 46(3/4): 234 .

Graebing, P., and Chib, J.S. 2004. Soil photolysis in a moisture-and temperature-controlled environment. 2. Insecticides. J Agric Food Chem 52(9): 2606-2614.

Johnson, P.C.D. 2014. Extension of Nakagawa \& Schielzeth's R_GLMM² to random slopes models. Methods Ecol Evol 5: 44-946

Knoepp, J.D., Vose, J.M., Michael, J.L., and B.C. Reynolds. 2012. Imidacloprid movement in soils and impacts on soil microarthropods in southern Appalachian eastern hemlock stands. J Environ Qual 41(2): 469-478.

Kuperman, R.G., Potapov, M.B., and E.A. Sinitzina. 2002. Precipitation and pollution interaction effect on the abundance of Collembola in hardwood forests in the lower Midwestern United States. Eur J Soil Biol 38(3-4): 277-280.

Mabubu, J., Nawaz, M., Cai, W., Zhao, J., He, Y., and H. Hua. 2017. Ecotoxicity of the neonicotinoid insecticides imidacloprid and thiacloprid to the soil-dwelling arthropod Folsomia candida (collembola). J Kans Entomol Soc 90: 323-333.

McCune, B., and J.B. Grace. 2002. Analysis of ecological communities. In: MjM Software Design. Gleneden Beach, Oregon.

McFadden D. 1979. Quantitative methods for analysing travel behavior of individuals: Some recent developments. In D. A. Hensher \& P. R. Stopher (Eds.), Behavioural travel modelling 279-318. London: Croom Helm. 
Nakagawa, S., and H. Schielzeth, 2013. A general and simple method for obtaining R2 from generalized linear mixed-effects models. Methods Ecol Evol 4(2): 133-142.

Nakagawa, S., Johnson, P.C.D., and H. Schielzeth. 2017. The coefficient of determination R ${ }^{2}$ and intra-class correlation coefficient from generalized linear mixed-effects models revisited and expanded. J R Soc Interface 14: 20170213.

Ogungbemi, A., and C. van Gestel. 2018. Extrapolation of imidacloprid toxicity between soils by exposing Folsomia candida in soil pore water. Ecotoxicology 27: 1107-1115.

Peck, D.C. 2009. Long-term effects of imidacloprid on the abundance of surface-and soil-active nontarget fauna in turf. Agric Forest Entomol 11(4): 405-419.

Perry, K.I., Wallin, K.F., Wenzel, J.W., and D.A. Herms. 2018. Forest disturbance and arthropods: Small-scale canopy gaps drive invertebrate community structure and composition. Ecosphere 9(10): e02463.

Ponge, J.F. 2000. Vertical distribution of Collembola (Hexapoda) and their food resources in organic horizons of beech forests. Biol Fert Soil, 32(6): 508-522.

Potapov, A.A., Semenina, E.E., Korotkevich, A.Y., Kuznetsova, N.A., and A.V. Tiunov. 2016. Connecting taxonomy and ecology: Trophic niches of collembolans as related to taxonomic identity and life forms. Soil Biol Biochem 101: 20-31.

Sarkar, M.A., Roy, S., Kole, R.K., and Chowdhury, A. 2001. Persistence and metabolism of imidacloprid in different soils of West Bengal. Pest Manag Sci 57(7): 598-602. 
Silcox, C. 2002. Using imidacloprid to control hemlock woolly adelgid. Proceedings Hemlock Woolly Adelgid in the Eastern United States. NJ Agricultural Experiment Station, New Brunswick, New Jersey, 280-287.

Singh, J., and D.K. Singh. 2005. Bacterial, azotobacter, actinomycetes, and fungal population in soil after diazinon, imidacloprid, and lindane treatments in groundnut (Arachis hypogaea L.) fields. J Environ Sci Health B 40(5): 785-800.

Smith, T.J., and C.M. McKenna. 2013. A comparison of logistic regression pseudo R2 indices. Multiple Linear Regression Viewpoints 39(2), 17-26.

Soil Survey Staff, Natural Resources Conservation Service, United States Department of Agriculture. Web Soil Survey. Available online. Accessed April 12 $2^{\text {th }}, 2020$.

Steward, B., and T.A. Horner. 1994. Control of Hemlock Woolly Adelgid with soil injections using Merit 2F (imidacloprid) and Metasystox-R2 (oxydemeton-methyl), 1993. Arthr Manag Tests 19(1): 348-348.

Takeda, H. 1995. A 5 year study of litter decomposition processes in a Chamaecyparis obtusa Endl Forest Ecol Res 10: 95-104.

Turcotte, Richard M. 2016. Temporal and Spatial Distribution of Imidacloprid and the Arthropod Fauna Associated with Eastern Hemlock, Tsuga canadensis (L.) Carr. Ph.D. Dissertation, West Virginia University, Morgantown, WV.

van Gestel, C., De Lima e Silva, C., Lam, T., Koekkoek, J., Lamoree, M., and R. Verweij. 2017. Multigeneration toxicity of imidacloprid and thiacloprid to Folsomia candida. Ecotoxicology 26: 320-328. 
Venables W.N., and B.D. Ripley. 2002. Modern Applied Statistics with S, Fourth edition. Springer, New York. ISBN 0-387-95457-0, https://www.stats.ox.ac.u/pub/MASS4/. 
Figures and Tables
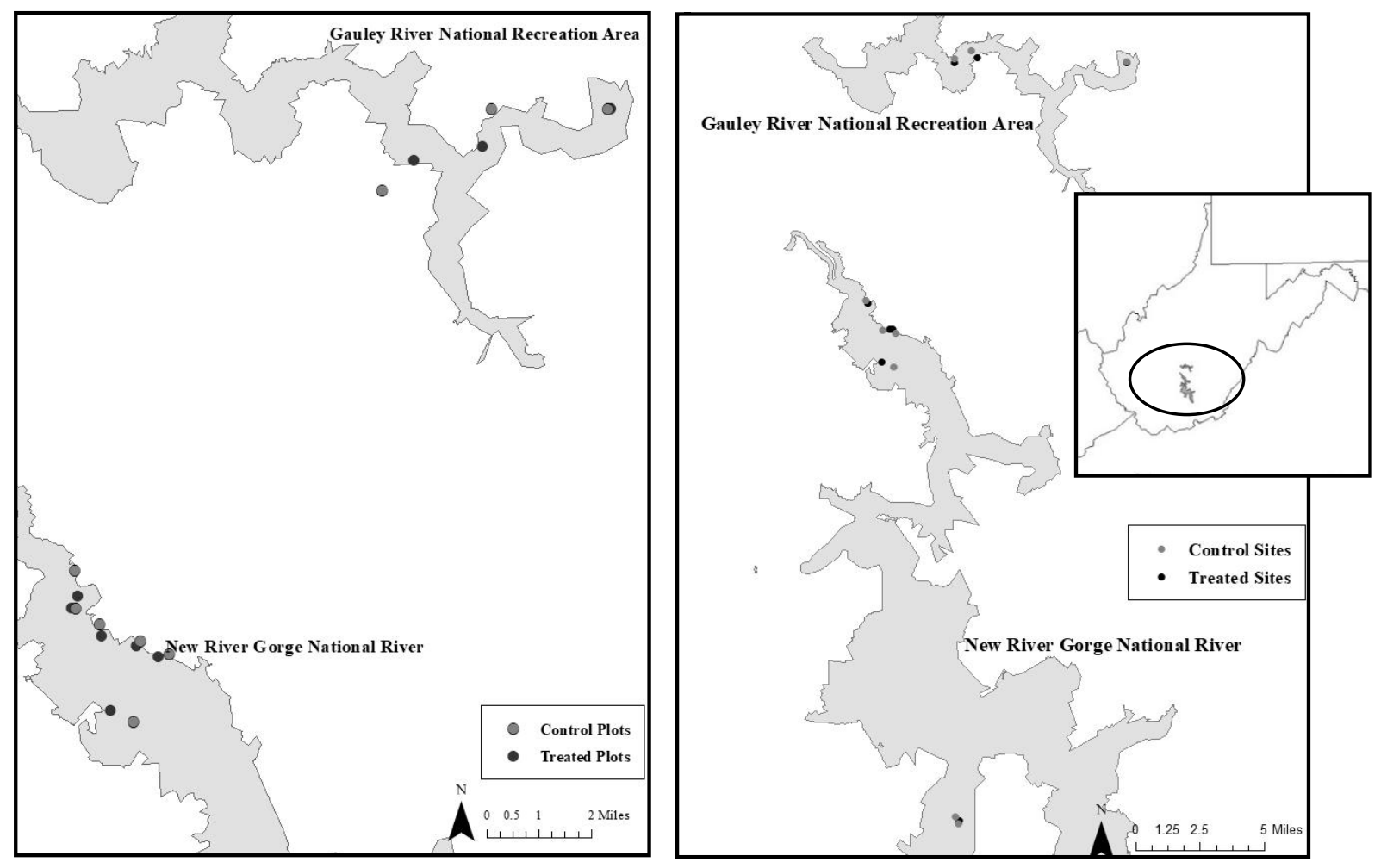

Figure 1: A total of 18 study sites, consisting of paired treated and control plots (36 plots total), were located in the Gauley River National Recreation Area (GARI) and New River Gorge National River (NERI), and surrounding land in southern West Virginia. To the right are the first group of sites sampled spring 2017 and summer 2017. To the left are the second group of sites sampled summer 2018 and spring 2019. Soil arthropod samples were collected to determine the effects of imidacloprid applications on soil collembolans in hemlock stands. 

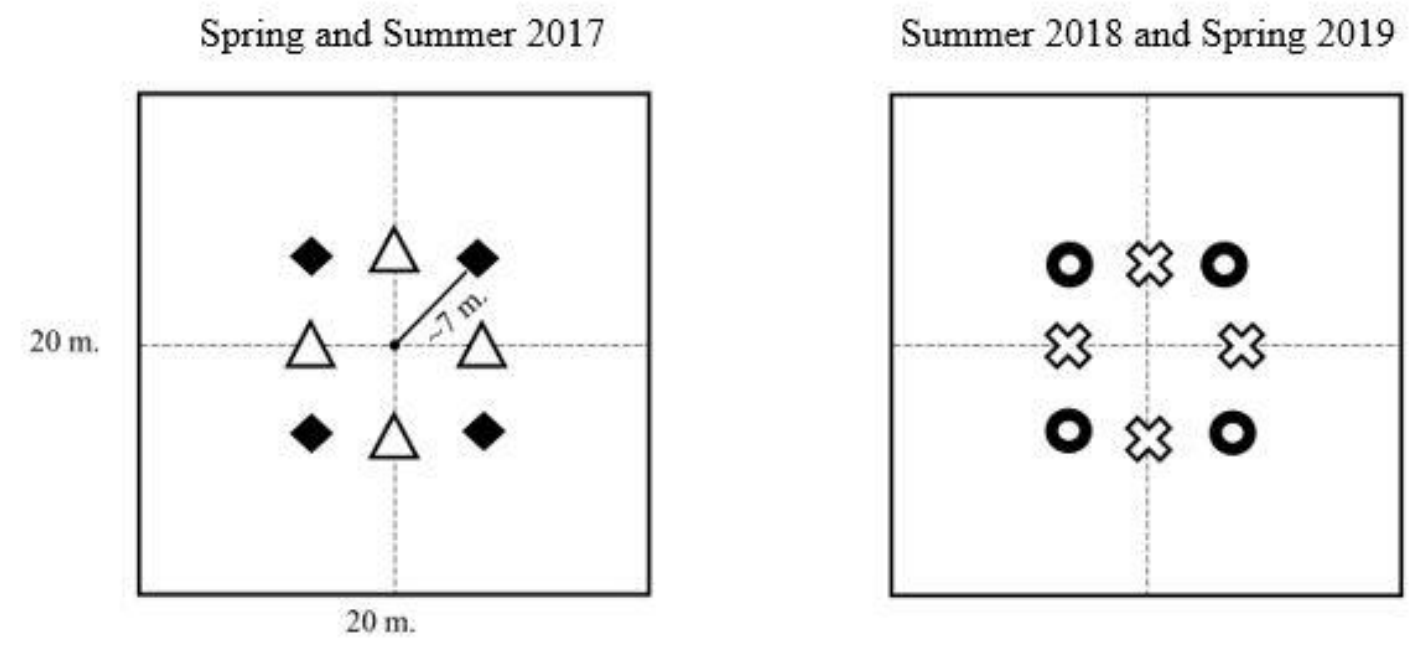

Figure 2: A total of four soil arthropod samples were extracted for each sampling period around $7 \mathrm{~m}$. from the center of the plots located in Gauley River National Recreation Area (GARI) and New River Gorge National River (NERI), and surrounding land in southern West Virginia. Nine paired plots were sampled in spring 2017 and summer 2017. Nine different sites were sampled in summer 2018 and spring 2019. A total of 18 paired sites were sampled. 


\section{Epedaphic}

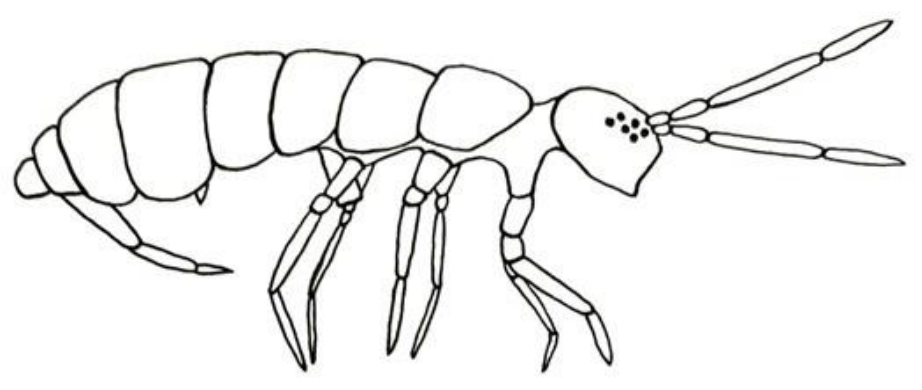

\section{Hemiedaphic}

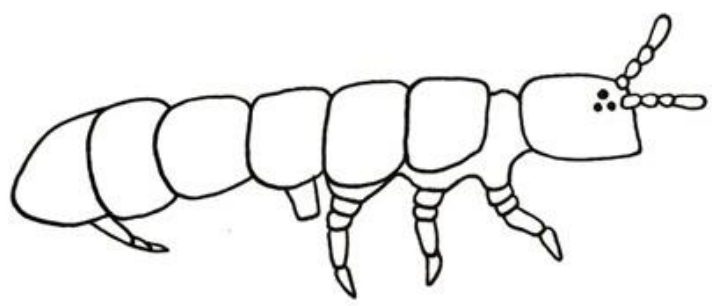

\section{Euedaphic}

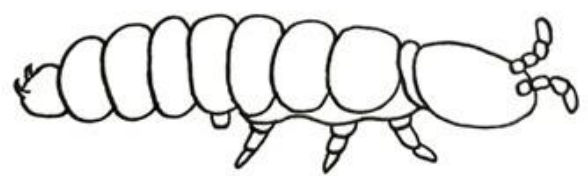

Figure 3: The soil collembolan trophic functionality groups in this study include epedaphic collembolans which live in the leaf litter and top surface of the soil. These collembolans have well-developed legs, furcula, and antennae, as well as pigmentation and many eye units.

Hemiedaphic collembolans live in the lower layer of soil and have less developed furcula, legs, and antennae. They also tend to have fewer eyes. Euedaphic collembolans live deep in the soil and usually do not have pigmentation, eyes, or a furcula. They also generally have short legs and antennae. 


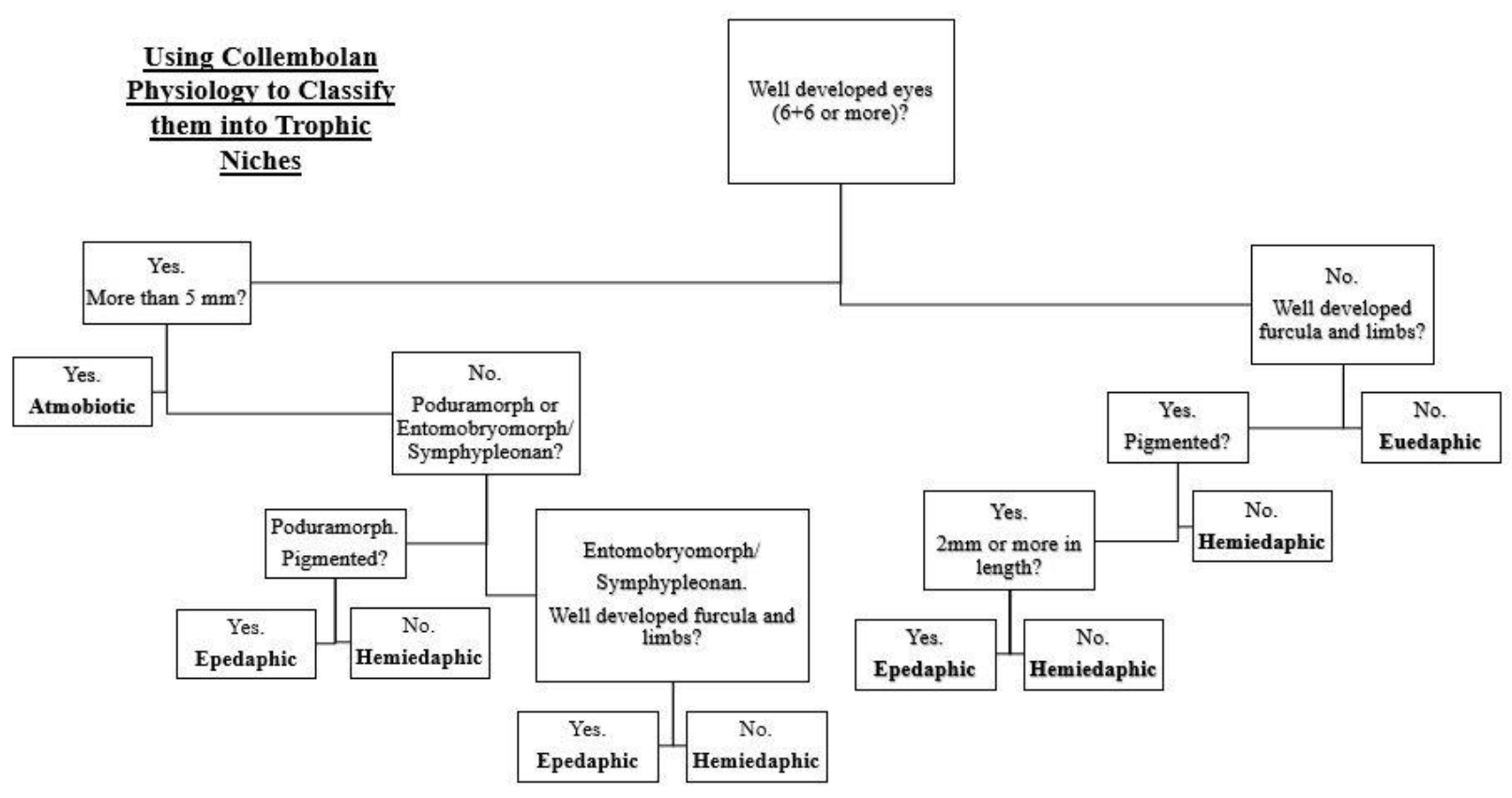

Figure 4: Flowchart used to classify soil collembolans into functional groups based on their morphological characteristics. Based on Faber (1991) and Potapov et al. (2016). Atmobiotic collembolans were not present for this study. 

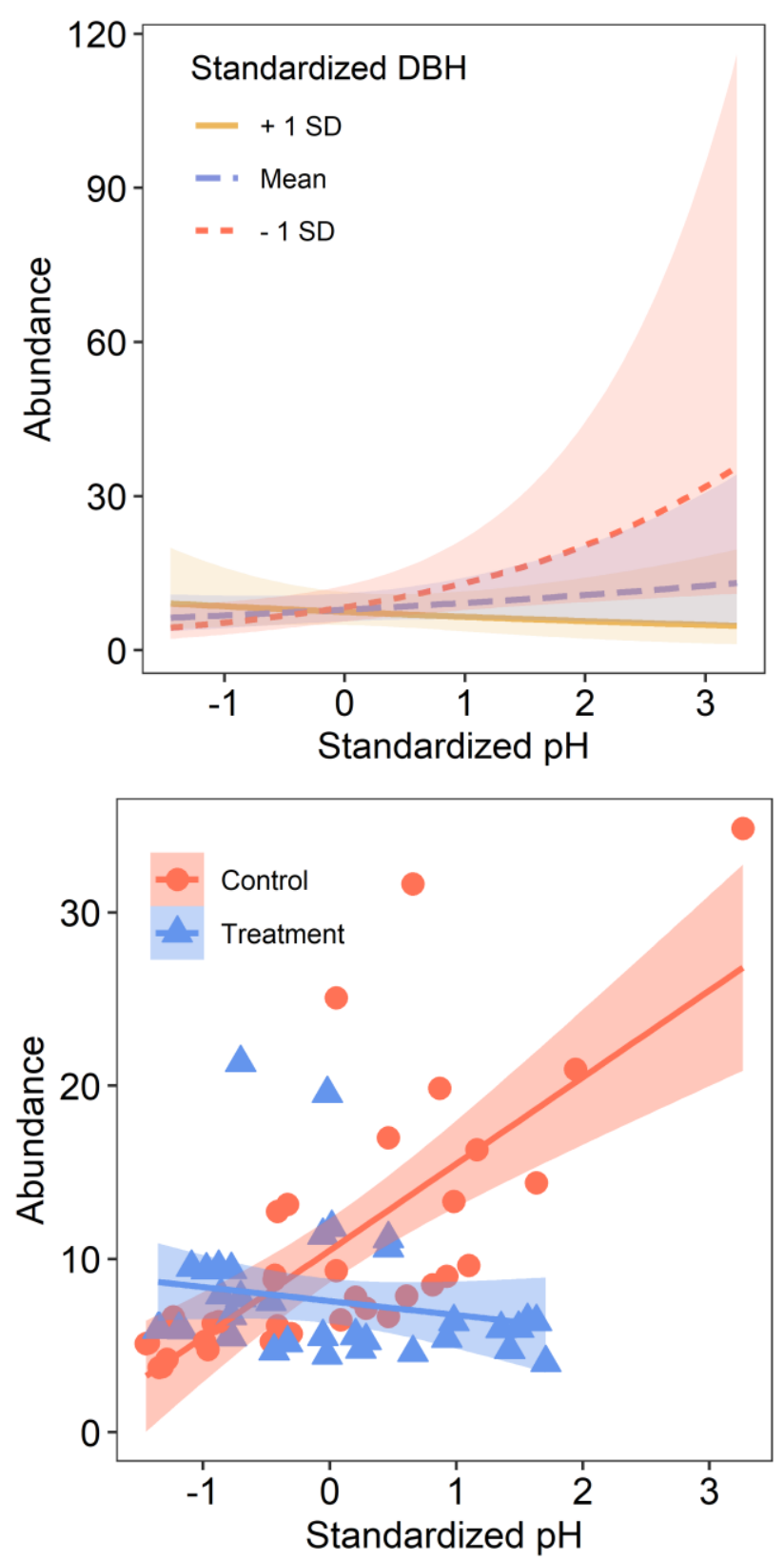

Figure 5: Epedaphic collembolan abundance in relation to treated tree diameter at breast height (DBH; top) and treatment history (Control/Treatment; bottom), while accounting for soil pH. For the DBH graph, lines represent expected abundance based on standardized $\mathrm{pH}$ values. For the treatment category graph, abundance data were plotted by standardized $\mathrm{pH}$ value, and a line of best fit was computed for the control and treatment plots. The model selection supported an interaction effect with $\mathrm{pH}$ for both variables (Table 2). 


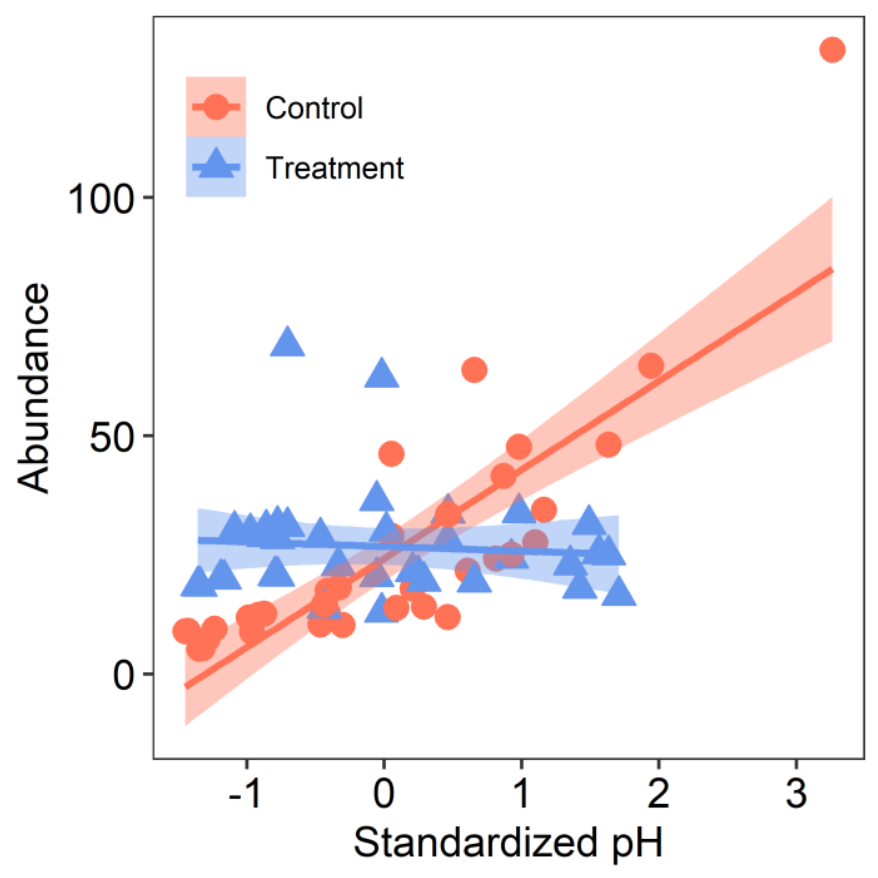

Figure 6: Hemiedaphic collembolan abundance in relation to treatment history (Control/Treatment), while accounting for soil $\mathrm{pH}$. Abundance data were plotted by standardized $\mathrm{pH}$ value, and a line of best fit was computed for the control and treatment plots. The model selection supported an interaction effect with $\mathrm{pH}$ (Table 2). 
Table 1: The 18 treated plots in this study were located in the Gauley River National Recreation Area (GARI) and New River Gorge National River (NERI), and surrounding land in southern West Virginia. The treated plots had varying treatment-related backgrounds. The years since last application (years post application) in treated plots ranged from 1-8 years. Burnwood 2 and Summersville Dam 2 were not treated within the plots, but trees surrounding the plot were treated. Some sites have a range for years since last treatment because they were sampled in 2018 and 2019. Years post application and DBH are not relevant for Summersville Dam 2 and Burnwood 2 because the plots were not treated, but the surrounding area was. Imidacloprid concentration refers to concentration in the soil.

\begin{tabular}{cccc}
\hline Site & $\begin{array}{c}\text { Years post } \\
\text { application }\end{array}$ & DBH & $\begin{array}{c}\text { Imidacloprid } \\
\text { concentration } \\
\text { (ng/g dry soil) }\end{array}$ \\
\hline Poll's Branch 1 & 1 & 23.6 & 0 \\
Poll's Branch 2 & 1 & 26.6 & 216.53 \\
Fern Creek 1 & 5 & 35.3 & 28.52 \\
Fern Creek 2 & 6 & 34.5 & 24.58 \\
Burnwood 1 & 6 & 23.0 & 0 \\
Kaymoor 1 & 5 & 32.0 & 0.87 \\
Richmond Chapel & 3 & 31.5 & 2.04 \\
Summersville Dam 1 & 3 & 46.7 & 4.36 \\
Wood's Ferry & 3 & 27.6 & 0.53 \\
Summersville Dam 2 & N/A & 0.0 & 0.64 \\
Carnifex Ferry & $2-3$ & 22.1 & 6.48 \\
Elliott Cutoff & $4-5$ & 34.5 & 20.88 \\
Burnwood 2 & N/A & 0.0 & 0 \\
Bridge Buttress & $5-6$ & 19.2 & 6.55 \\
Fern Buttress & $2-3$ & 34.1 & 0 \\
Fern Creek 4 & $7-8$ & 45.7 & 0 \\
Nuttall & $5-6$ & 42.1 & 0 \\
Kaymoor 2 & $2-3$ & 33.7 & 0 \\
\hline
\end{tabular}


Table 2: Generalized linear mixed models (GLMMs) with a negative binomial distribution were used to determine the effects of imidacloprid on collembolans at the study site located in the Gauley River National Recreation Area (GARI) and New River Gorge National River (NERI), and surrounding land in southern West Virginia. Akaike's Information Criterion corrected for small sample size (AICc) was used for model selection. Overall collembolan diversity, abundance, and morphospecies richness were the response variables for the first group of models. Abundance and richness were also tested for each trophic level (epedaphic, hemiedaphic, and euedaphic). The treatment-related variables mean were diameter at breast height $(\mathrm{cm})$ of treated trees within plots $(\mathrm{DBH})$ and whether the plots had a history of being treated or not (Treatment). Soil $\mathrm{pH}(\mathrm{pH})$ and composition (Soil) were explanatory environmental variables. The null model $(\sim 1)$ was used to determine which models were possibly supported.

\begin{tabular}{|c|c|c|c|c|c|c|c|c|c|c|c|}
\hline \multirow{2}{*}{$\begin{array}{c}\text { Collembolan Community } \\
\text { Metrics }\end{array}$} & \multicolumn{3}{|c|}{ Diversity } & \multicolumn{5}{|c|}{ Abundance } & \multicolumn{3}{|c|}{ Richness } \\
\hline & $\mathrm{AICc}$ & $\triangle \mathrm{AICc}$ & AICc Wt. & & $\mathrm{AICc}$ & $\triangle \mathrm{AICc}$ & AICc Wt. & & $\mathrm{AICc}$ & $\triangle \mathrm{AICc}$ & AICc Wt. \\
\hline Null & 206.26 & 0.000 & 0.423 & Soil & 811.30 & 0.000 & 0.249 & $\mathrm{pH}$ & 517.65 & 0.000 & 0.263 \\
\hline $\mathrm{pH}$ & 208.32 & 2.064 & 0.151 & $\mathrm{pH}$ & 812.29 & 0.989 & 0.152 & Null & 518.30 & 0.648 & 0.190 \\
\hline DBH & 208.50 & 2.242 & 0.138 & Null & 812.57 & 1.272 & 0.132 & $\mathrm{DBH} \times \mathrm{pH}$ & 519.47 & 1.819 & 0.106 \\
\hline Treatment & 208.50 & 2.243 & 0.138 & $\mathrm{DBH}+$ Soil & 813.62 & 2.321 & 0.078 & Treatment $\mathrm{x} \mathrm{pH}$ & 519.91 & 2.259 & 0.085 \\
\hline $\mathrm{DBH}+\mathrm{pH}$ & 210.64 & 4.375 & 0.048 & Treatment + Soil & 813.72 & 2.418 & 0.074 & $\mathrm{DBH}+\mathrm{pH}$ & 519.95 & 2.305 & 0.083 \\
\hline Treatment $+\mathrm{pH}$ & 210.64 & 4.375 & 0.047 & Treatment $\mathrm{x}$ pH & 813.73 & 2.435 & 0.074 & Treatment $+\mathrm{pH}$ & 520.28 & 2.630 & 0.071 \\
\hline DBH x pH & 212.75 & 6.490 & 0.017 & $\mathrm{DBH} \times \mathrm{pH}$ & 814.38 & 3.080 & 0.053 & Treatment & 520.36 & 2.711 & 0.068 \\
\hline Treat $\mathrm{x}$ pH & 212.93 & 6.667 & 0.015 & $\mathrm{DBH}+\mathrm{pH}$ & 814.44 & 3.142 & 0.052 & $\mathrm{DBH}$ & 520.52 & 2.873 & 0.063 \\
\hline Soil & 213.00 & 6.737 & 0.015 & Treatment $+\mathrm{pH}$ & 814.59 & 3.288 & 0.048 & Soil & 521.17 & 3.526 & 0.045 \\
\hline DBH + Soil & 215.45 & 9.186 & 0.004 & $\mathrm{DBH}$ & 814.75 & 3.457 & 0.044 & Treatment + Soil & 523.50 & 5.854 & 0.014 \\
\hline Treatment + Soil & 215.46 & 9.195 & 0.004 & Treatment & 814.77 & 3.469 & 0.044 & DBH + Soil & 523.63 & 5.983 & 0.013 \\
\hline
\end{tabular}


Table 2 continued

\begin{tabular}{|c|c|c|c|c|c|c|c|c|c|c|c|c|}
\hline \multirow{2}{*}{$\begin{array}{c}\text { Trophic Group } \\
\text { Abundance }\end{array}$} & \multicolumn{3}{|c|}{ Epedaphic } & \multicolumn{5}{|c|}{ Hemiedaphic } & \multicolumn{4}{|c|}{ Euedaphic } \\
\hline & AICc & $\Delta \mathrm{AICc}$ & AICc Wt. & & & $\mathrm{AICc}$ & $\Delta \mathrm{AICc}$ & AICc Wt. & & $\mathrm{AICc}$ & $\triangle \mathrm{AICc}$ & $\begin{array}{l}\text { AICc } \\
\text { Wt. }\end{array}$ \\
\hline Treatment x pH & 483.19 & 0.000 & 0.170 & \multicolumn{2}{|l|}{ Soil } & 622.64 & 0.000 & 0.309 & Soil & 716.87 & 0.000 & 0.270 \\
\hline $\mathrm{DBH} \times \mathrm{pH}$ & 483.51 & 0.318 & 0.145 & \multicolumn{2}{|l|}{ Treatment x pH } & 624.05 & 1.412 & 0.152 & Null & 717.93 & 1.067 & 0.158 \\
\hline $\mathrm{pH}$ & 483.73 & 0.541 & 0.130 & \multicolumn{2}{|l|}{ DBH + Soil } & 624.84 & 2.198 & 0.103 & $\mathrm{pH}$ & 718.08 & 1.215 & 0.147 \\
\hline Soil & 484.15 & 0.959 & 0.105 & \multicolumn{2}{|l|}{ Treatment + Soil } & 624.93 & 2.292 & 0.098 & $\mathrm{DBH}+$ Soil & 719.02 & 2.157 & 0.092 \\
\hline Null & 484.21 & 1.021 & 0.102 & \multicolumn{2}{|l|}{ Null } & 625.42 & 2.777 & 0.077 & Treatment + Soil & 719.26 & 2.395 & 0.082 \\
\hline Treatment & 484.87 & 1.684 & 0.073 & \multicolumn{2}{|l|}{ DBH x pH } & 625.45 & 2.807 & 0.076 & Treatment & 720.05 & 3.183 & 0.055 \\
\hline Treatment $+\mathrm{pH}$ & 485.12 & 1.925 & 0.065 & \multicolumn{2}{|l|}{$\mathrm{pH}$} & 626.02 & 3.376 & 0.057 & DBH & 720.09 & 3.226 & 0.054 \\
\hline Treatment + Soil & 485.16 & 1.968 & 0.064 & \multicolumn{2}{|l|}{ Treatment $+\mathrm{pH}$} & 627.06 & 4.417 & 0.034 & $\mathrm{DBH}+\mathrm{pH}$ & 720.22 & 3.352 & 0.051 \\
\hline $\mathrm{DBH}+\mathrm{pH}$ & 485.51 & 2.319 & 0.053 & \multicolumn{2}{|l|}{ Treatment } & 627.09 & 4.450 & 0.033 & Treatment $+\mathrm{pH}$ & 720.39 & 3.519 & 0.047 \\
\hline DBH & 485.66 & 2.469 & 0.049 & DBH & & 627.11 & 4.467 & 0.033 & Treatment x pH & 721.82 & 4.951 & 0.023 \\
\hline DBH + Soil & 485.91 & 2.715 & 0.044 & $\mathrm{DBH}+\mathrm{pH}$ & & 627.47 & 4.832 & 0.028 & $\mathrm{DBH} \times \mathrm{pH}$ & 721.91 & 5.041 & 0.022 \\
\hline \multirow[b]{2}{*}{ Trophic Group Richness } & \multicolumn{3}{|c|}{ Epedaphic } & \multicolumn{4}{|c|}{ Hemiedaphic } & & \multicolumn{4}{|c|}{ Euedaphic } \\
\hline & $\mathrm{AICc}$ & $\Delta \mathrm{AICc}$ & AICc Wt. & & AICc & & $\triangle \mathrm{AICc}$ & AICc Wt. & & AICc & $\Delta \mathrm{AICc}$ & $\begin{array}{l}\text { AICc } \\
\text { Wt. }\end{array}$ \\
\hline Null & 348.74 & 0.000 & 0.295 & DBH & 378.63 & & 0.000 & 0.186 & DBH & 406.11 & 0.000 & 0.316 \\
\hline DBH & 349.04 & 0.292 & 0.255 & Null & 378.67 & & 0.046 & 0.182 & Treatment & 406.65 & 0.540 & 0.241 \\
\hline Treatment & 350.61 & 1.867 & 0.116 & $\mathrm{DBH}+\mathrm{pH}$ & 379.12 & & 0.498 & 0.145 & Null & 407.79 & 1.677 & 0.137 \\
\hline $\mathrm{pH}$ & 350.92 & 2.172 & 0.100 & $\mathrm{pH}$ & 379.16 & & 0.529 & 0.143 & $\mathrm{DBH}+\mathrm{pH}$ & 408.39 & 2.276 & 0.101 \\
\hline $\mathrm{DBH}+\mathrm{pH}$ & 351.26 & 2.519 & 0.084 & Treatment & 379.84 & & 1.216 & 0.101 & Treatment $+\mathrm{pH}$ & 408.96 & 2.849 & 0.076 \\
\hline $\mathrm{DBH} * \mathrm{pH}$ & 351.99 & 3.247 & 0.058 & Treatment $+\mathrm{pH}$ & 380.11 & & 1.480 & 0.089 & $\mathrm{pH}$ & 410.01 & 3.895 & 0.045 \\
\hline Treatment $+\mathrm{pH}$ & 352.82 & 4.080 & 0.038 & $\mathrm{DBH} * \mathrm{pH}$ & 380.45 & & 1.822 & 0.075 & $\mathrm{DBH} * \mathrm{pH}$ & 410.33 & 4.221 & 0.038 \\
\hline Soil & 354.23 & 5.488 & 0.019 & Treatment $* \mathrm{pH}$ & 380.85 & & 2.222 & 0.061 & Treatment $* \mathrm{pH}$ & 411.33 & 5.216 & 0.023 \\
\hline Treatment $* \mathrm{pH}$ & 354.71 & 5.970 & 0.015 & Soil & 385.22 & & 6.593 & 0.007 & DBH + Soil & 412.94 & 6.830 & 0.010 \\
\hline DBH + Soil & 354.92 & 6.172 & 0.013 & $\mathrm{DBH}+$ Soil & 385.49 & & 6.861 & 0.006 & Treatment + Soil & 413.55 & 7.439 & 0.008 \\
\hline Treatment + Soil & 356.35 & 7.607 & 0.007 & Treatment + Soil & 386.67 & & 8.038 & 0.003 & Soil & 414.63 & 8.523 & 0.004 \\
\hline
\end{tabular}


Table 3: Generalized linear mixed models (GLMM) with a negative binomial distribution were used to determine the effects of imidacloprid on collembolan communities in hemlock stands located in the Gauley River National Recreation Area (GARI) and New River Gorge National River (NERI), and surrounding land in southern West Virginia. Community metric (abundance, diversity, and richness) models with a lower AICc score than the null model $(\sim 1)$ and with a treatment-related variable were used to determine the impacts of imidacloprid applications on the collembolan community, along with models with non-treatment-related environmental variables when they can be compared alongside the treatment-related variables. The $85 \%$ confidence intervals (CIs), coefficient ( $\beta$ ) estimates, and Pseudo $\mathrm{R}^{2}$ for GLMMs values were used to determine the model support. Treatment-related variables included plots with a treatment history vs. control plots (Treatment)and average diameter at breast height of trees treated within the plots (DBH). DBH was used because the amount of imidacloprid applied for hemlock woolly adelgid control is dependent on the $\mathrm{DBH}$ of the tree being treated.

\begin{tabular}{|c|c|c|c|c|c|}
\hline Model & Variable & $\beta$ (estimate) & $\begin{array}{l}\text { Lower CI } \\
(7.5 \%)\end{array}$ & $\begin{array}{l}\text { Upper CI } \\
(92.5 \%)\end{array}$ & GLMM-R ${ }^{2}$ \\
\hline \multicolumn{6}{|c|}{ Epedaphic Abundance } \\
\hline \multirow[t]{4}{*}{ Treatment $\mathrm{x} \mathrm{pH}$} & Intercept & 2.164 & 1.87 & 2.46 & 0.085 \\
\hline & Treatment & -0.232 & -0.56 & 0.10 & \\
\hline & $\mathrm{pH}$ & 0.385 & 0.15 & 0.63 & \\
\hline & Treatment:pH & -0.513 & -0.86 & -0.16 & \\
\hline \multirow[t]{4}{*}{$\mathrm{DBH} \times \mathrm{pH}$} & Intercept & 2.07 & 1.81 & 2.31 & 0.106 \\
\hline & $\mathrm{DBH}$ & -0.06 & -0.23 & 0.11 & \\
\hline & $\mathrm{pH}$ & 0.15 & -0.05 & 0.36 & \\
\hline & DBH:pH & -0.29 & -0.49 & -0.09 & \\
\hline \multicolumn{6}{|c|}{ Hemiedaphic Abundance } \\
\hline \multirow[t]{4}{*}{ Treatment $\mathrm{x} \mathrm{pH}$} & Intercept & 2.89 & 2.56 & 3.22 & 0.119 \\
\hline & Treatment & 0.32 & -0.08 & 0.72 & \\
\hline & $\mathrm{pH}$ & 0.53 & 0.23 & 0.84 & \\
\hline & Treatment:pH & -0.68 & -1.10 & -0.27 & \\
\hline \multicolumn{6}{|c|}{ Hemiedaphic Richness } \\
\hline \multirow[t]{2}{*}{ DBH } & Intercept & 1.617 & 1.46 & 1.76 & 0.028 \\
\hline & $\mathrm{DBH}$ & 0.116 & 0.01 & 0.23 & \\
\hline \multicolumn{6}{|c|}{ Euedaphic Richness } \\
\hline \multirow[t]{2}{*}{ Treatment } & Intercept & 1.729 & 1.55 & 1.90 & 0.039 \\
\hline & Treatment & 0.260 & 0.06 & 0.46 & \\
\hline \multirow[t]{2}{*}{ DBH } & Intercept & 1.861 & 1.72 & 2.00 & 0.047 \\
\hline & $\mathrm{DBH}$ & 0.143 & 0.04 & 0.25 & \\
\hline
\end{tabular}


Table 4: The collembolan morphospecies most correlated with imidacloprid applications in hemlock stands located in the Gauley River National Recreation Area (GARI) and New River Gorge National River (NERI), and surrounding land in southern West Virginia were determined. Species scores were extracted from a redundancy analysis (RDA) with treatment history as the explanatory variable Collembolan morphospecies were considered correlated with the treatmentrelated variables if their species scores were $\geq 0.070$ or $\leq-0.070$. Negative species scores indicate a negative correlation and positive species scores indicate a positive correlation. The abundance of each morphospecies in sites with a history of imidacloprid applications (treat) and with no history of treatments (control) were included. Family was also listed, except for the order Symphypleona which was not identified past order.

\begin{tabular}{llll}
\hline Morphospecies & Family/Order & $\begin{array}{l}\text { Species } \\
\text { score }\end{array}$ & $\begin{array}{l}\text { Abundance } \\
\text { (control/treat) }\end{array}$ \\
\hline Treatment History & Hypogastruridae & 0.094 & $1 / 12$ \\
Hypogastrurid 6 & Hypogastruridae & 0.092 & $1 / 12$ \\
Hypogastrurid 2 & Symphypleona & -0.096 & $6 / 0$ \\
Symphypleona 15 & Symphypleona & -0.086 & $18 / 1$ \\
Symphypleona 18 & Symphypleona & -0.081 & $8 / 1$ \\
Symphypleona 9 & & & \\
\hline
\end{tabular}


Table 5: There were 11 collembolan families (including the order Symphypleona) collected from the paired sites located in the Gauley River National Recreation Area (GARI) and New River Gorge National River (NERI), and surrounding land in southern West Virginia. These samples were collected between spring 2017 - spring 2019. Sampled in the treated plots had a variable treatment history to control hemlock woolly adelgid using the insecticide, imidacloprid.

Collembolans in Isotomidae were most abundant, followed by Onychiuridae and Entomobryidae. The total count, mean, and standard error (SE) were calculated for the families in control and treated plots.

\begin{tabular}{lccc|ccc}
\hline & \multicolumn{3}{c|}{ Treated Plots } & \multicolumn{3}{c}{ Control Plots } \\
\cline { 2 - 7 } Family & Count & Mean & SE & Count & Mean & SE \\
\hline Isotomidae & 2320 & 64.4 & 26.5 & 2374 & 65.9 & 18.9 \\
Symphypleona & 85 & 2.4 & 1.0 & 124 & 3.4 & 1.2 \\
Neelidae & 89 & 2.5 & 0.9 & 96 & 2.7 & 0.8 \\
Hypogastruridae & 102 & 2.8 & 1.2 & 59 & 1.6 & 0.5 \\
Onychiuridae & 491 & 13.6 & 4.8 & 316 & 8.8 & 2.00 \\
Odontellidae & 24 & 0.7 & 0.3 & 16 & 0.4 & 0.1 \\
Tullbergiidae & 207 & 5.8 & 2.2 & 332 & 9.2 & 4.4 \\
Tomoceridae & 110 & 3.1 & 1.1 & 178 & 4.9 & 0.9 \\
Entomobryidae & 380 & 10.6 & 2.2 & 358 & 9.9 & 2.5 \\
Neanuridae & 99 & 2.8 & 0.8 & 146 & 4.1 & 1.8 \\
Oncopoduridae & 35 & 1.0 & 0.5 & 28 & 0.8 & 0.4 \\
\hline
\end{tabular}




\title{
Chapter 3: Long-term effects of imidacloprid on the diversity and richness of soil fungi and bacteria in hemlock stands
}

\begin{abstract}
Imidacloprid, a neonicotinoid insecticide, has been used for over a decade to protect eastern hemlock trees from the spread of an invasive insect, hemlock woolly adelgid, throughout forests in the eastern United States. This study examined the long-term effects of imidacloprid on soil fungi and bacteria in the New River Gorge National River (NERI) and Gauley River National Recreation Area (GARI). Soil samples were collected from 9 sites divided into paired plots with one plot that had been treated with imidacloprid at different times over the past decade and the other plot being untreated. Imidacloprid concentration was measured at each site and imidacloprid was detected in 4 of the 9 treated plots, ranging from $0.64-20.8 \mathrm{ng} / \mathrm{g}$. The bacterial and fungal community DNA was sequenced from the soil samples, then processed in program QIIME. The data was analyzed using Akaike's information criterion corrected for small sample size (AICc) and species scores extracted from RDAs. Fungal sequences were classified into 428,976 amplicon sequence variants (ASVs) that were classified into 603 groups. Bacterial sequences were classified into 457,330 bacterial ASVs that were classified into 1,117 groups. Bacterial diversity and richness were negatively correlated with low $\mathrm{pH}$ which accounted for most of the environmental factor explanatory power. Diversity and richness of fungi were not affected by treatment history, or mean diameter at breast height $(\mathrm{DBH}$ in $\mathrm{cm})$ of treated trees within plots. The bacterial and fungal groups with the strongest correlation between presence and absence of past treatments in or near plots were noted. Overall, imidacloprid applications did not have strong long-term effects on soil bacteria and fungi, but individual taxa may be affected.
\end{abstract}


Keywords: fungi, bacteria, imidacloprid, forest, microbial community

\section{Introduction}

Soil bacteria and fungi are critical for key ecosystem functions (van der Heijden et al. 2008), drive important systems such as nutrient cycling (Tiedje 1988, Kowalchuk and Stephen 2001) and soil formation (Rillig and Mummey 2006, Hobara 2013), and are crucial for decomposition of soil organic matter (van Veen and Kuikman 1990). These microbes can be impacted by environmental contaminants. For example, Wang et al (2008) tested the effects of an organophosphate insecticide, methamidophos, on the microbial community and found that it reduced total microbial biomass carbon and decreased overall genetic diversity. At the same time, it improved catabolic activity and increased the biomass of gram-negative bacteria. When Martínez-Toledo et al. (1998) tested the effects of a fungicide, Captan, on the microbial community, total culturable fungi, nitrifying bacteria, and nitrogenase activity decreased while denitrifying activity and total culturable bacteria increased. The effects of pesticides are complex and variable, can be long-lasting or transient, and can increase or decrease microbial populations (Johnsen et al. 2001, Seymour et al. 2005).

Hemlock woolly adelgid (HWA), Adelges tsugae (Hemiptera: Adelgidae), is an invasive insect species from Japan causing the decline of eastern hemlock trees throughout the eastern United States (McClure 2001). Currently, the most effective control for HWA is imidacloprid, a neonicotinoid insecticide. Neonicotinoid pesticides target the insect's nervous system by binding to the nicotineric receptors which eventually result in the insect's death (Liu and Casida 1993). Imidacloprid is applied as a soil injection, soil drench, or trunk injection which is systemically translocated throughout the tree after application (Elbert et al. 1991), Imidacloprid prevents and 
represses HWA populations (Steward and Horner 1994, Silcox 2002), but there have been concerns about the non-target effects of this insecticide.

Previous studies examined the effects of imidacloprid on microbial communities from agricultural and field soils (Cycoń et al. 2013, Cycoń and Piotrowska-Seget 2015a, Cycoń and Piotrowska-Seget 2015b, Zhang et al. 2015, Mahapatra et al. 2017, Li et al. 2018), but have only considered the short-term effects (< a year post application) of applications in production agriculture. Imidacloprid has a highly variable half-life of 19-1230 days depending on soil conditions. Imidacloprid's half-life increases in soils with higher pH (Sarkar et al. 1999, Sarkar et al. 2001) and lower organic matter content (Broznić and Milin 2013). Imidacloprid can control HWA for 6 years after being used to treat trees (Silcox et al. 2002, Benton et al. 2016b). However, the long-term effects ( $\geq$ a year post application) of imidacloprid on soil microbial communities have not been reported. In addition, the previous studies were focused on field crop applications of imidacloprid which are usually sprayed evenly on a field. When applying imidacloprid to control HWA in forests, the soil is injected and taken up systemically through the tree's roots or directly injected into the tree trunk. These differing application methods, as well as the short length of the studies leave a knowledge gap.

Some previous studies found that, when applied at the recommended field rate (i.e., 1-2.5 $\mathrm{g} / \mathrm{kg}$ of soil), imidacloprid negatively impacted the soil microbial community, but the effects were transient and the communities recovered (Cycoń et al 2013, Mahapatra 2017, Li et al. 2018). A 56-day study by Cycoń and Piotrowska-Seget (2015a) found significant negative impacts from imidacloprid applied at the field rate $(1 \mathrm{~g} / \mathrm{kg}$ soil) and 10 times the field rate (i.e., $10 \mathrm{~g} / \mathrm{kg}$ soil) on soil respiration, enzyme activities, nitrogen transformation, and overall number of bacteria. When imidacloprid was applied at 10 times the field rate there were significant 
negative impacts on the fungal and bacterial community structure, but similar results were not observed at the field rate (Cycoń et al 2013). Another study by Cycoń and Piotrowska-Seget (2015b) found that ammonia-oxidizing bacteria increased in diversity and richness after imidacloprid application while ammonia-oxidizing archaea were suppressed and nitrification rates in the soil were negatively affected. The study hypothesized that this change in community was likely caused by an increase in the concentration of $\mathrm{N}-\mathrm{NH}_{4}{ }^{+}$which is favorable for ammonia-oxidizing bacteria and unfavorable for ammonia-oxidizing archaea. These studies suggest that imidacloprid does impact the microbial communities, but only examines the shortterm effects.

In the New River Gorge National River (NERI), and Gauley River National Recreation Area (GARI) in southern West Virginia over 10,000 hemlock trees have been treated with imidacloprid through soil or trunk injections since 2006 (Strickler 2012). After over a decade of use, this study examined the long-term effects of imidacloprid on hemlock stands with varying treatment histories. A recent study by Crayton et al. (2020) that used the same study area discovered bioaccumulation of imidacloprid in benthic macroinvertebrates and aquatic salamanders that were in streams adjacent to imidacloprid applications. The objectives of this study were to (1) determine the long-term effects of imidacloprid applications in hemlock stands on the soil bacterial and fungal communities and (2) identify specific soil bacterial and fungal taxa that are influenced by imidacloprid applications. This study is the first to examine the effects of imidacloprid on bacterial and fungal communities in a forest ecosystem, as well as the first to consider the effects past the first year of application. 


\section{Materials and Methods}

\section{Study sites and treatment history}

The study sites were located on National Park Service land within the New River Gorge National River (NERI), and Gauley River National Recreation Area (GARI) in southern West Virginia (Figure 1). The study areas were being used for several related studies on long-term effects of imidacloprid on different organisms (i.e., salamanders, mites, collembolans, benthic macroinvertebrates). Each of the 9 sites was within a hemlock stand and consisted of one plot that was treated with imidacloprid and one untreated control plot (i.e., a total of 18 plots). Each plot was $20 \mathrm{~m} \times 20 \mathrm{~m}$ to accommodate an adjacent study on the long-term effects of imidacloprid on salamanders. The plots were divided into equal quadrants. The treated plots had been treated with imidacloprid applications within the study sites starting in 2006 (Table 1). Sites were treated 2-9 years before the soil samples were collected.

\section{Soil pH and Moisture Measurements, and Imidacloprid Extraction}

Mineral soil pH was measured at the center of each plot's quadrant using an EcoSense pH100A meter (YSI, Yellow Springs, Ohio). Soil moisture (i.e., mineral soil volumetric water content) was measured using a FieldScout TDR100 Soil Moisture Meter (Spectrum Technologies, Aurora, Illinois). Soil moisture and $\mathrm{pH}$ were measured in spring and summer of 2018 and the average of the quadrants was used as a representation of the respective plots. The soil texture (loam, sandy loam, gravelly loam, and silt loam) for each plot was determined using Soil Survey Geographic database (SSURGO) (USDA 2020).

To measure the concentration of imidacloprid in the soil, soil samples were systematically taken from each plot with a $1.9-\mathrm{cm}$-diameter soil probe to a depth of $25 \mathrm{~cm}$. The 
site quadrants were broken into sub-quadrants and a sample was taken from the center of each, for a total of 16 samples per plot which were mixed and combined into one sample. Soil samples were freeze-dried, homogenized, and $\sim 5 \mathrm{~g}$ dry weight of soil per sample was extracted and combined with $500 \mathrm{mg}$ of carbon and $900 \mathrm{mg}$ of magnesium sulfate. Samples were spiked with the surrogate compound $d_{4}$-imidacloprid (Cambridge Isotope, Andover, MA) and then extracted using acetonitrile solvent at $100{ }^{\circ} \mathrm{C}$. The acetonitrile extracts were reduced under nitrogen gas and centrifuged to removed particulates. The final extract was $0.2 \mathrm{~mL}$ in 50:50 acetonitrile:water which was spiked with an internal standard ( $d_{3}$-clothianidin; Cambridge Isotope).

Samples were analyzed using liquid chromatography tandem mass spectrometry (LCMS/MS). Flow rate was $0.6 \mathrm{ml} \mathrm{min}^{-1}$ and the mobile phase solvents were $0.1 \%$ formic acid in water (A) and acetonitrile (B). The column gradient was 2:98 (A:B) from 0-2 min; 2-4 min increase to 50:50 (A:B), hold for $3 \mathrm{~min}$; 7-7.5 min decrease to 2:98 (A:B), hold for $4.5 \mathrm{~min}$. MS/MS conditions were electrospray (ESI) ionization, positive mode, drying gas temperature at $350^{\circ} \mathrm{C}$, drying gas flow at $10 \mathrm{~L} / \mathrm{min}$, capillary voltage at 4,000 V, and nebulizer at $40 \mathrm{psi}$. Data were collected in the multiple-reaction-monitoring (MRM) mode. The method detection level was $0.2 \mathrm{ng} / \mathrm{g}$ for all compounds. Further details of the LC-MS/MS analytical method can be found elsewhere (Hladik and Calhoun, 2012). Recovery of the surrogate ( $d_{4}$-imidacloprid) was lower (30-70\%) than other soil studies (>70\%), likely due to the organic content of the samples; data were surrogate recovery corrected.

\section{Soil sampling for microbial community analysis}

To determine community richness and diversity of soil fungi and bacteria, soil samples were taken in September 2018, a period in which ample soil moisture supported high microbial 
activity (Barros et al. 1995, National Center for Environmental Information 2020). The samples were taken to a depth of $10 \mathrm{~cm}$ (A horizon) with a 1.9-cm-diameter soil corer. Soil samples were collected about $7 \mathrm{~m}$ from the center of the plots. Two samples were collected within each quadrant for a total of eight samples per plot. The eight samples were then combined, sieved on site through a 1-mm sieve and put on ice, yielding one homogenized sample per plot. Within the same day the samples were put into a $-80^{\circ} \mathrm{C}$ freezer upon return to the laboratory.

\section{DNA extraction, amplification, and sequencing for microbial community analysis}

A 250-mg aliquot of soil for each sample was used for DNA isolation using the DNeasy PowerSoil kit (Qiagen, Germantown, MD) by following the manufacturer's instructions. Quantitative PCR was then used to quantify the bacterial and archaeal 16S rRNA and fungal internal transcribed spacer (ITS) region of the gene copies in each sample and to standardize the gene copies per sample prior to sequencing. All DNA quantification was performed on a

QuantStudio 5 RT-PCR instrument (ThermoFisher, Waltham, MA). To characterize the bacterial and fungal community, the bacterial and archaeal 16S rRNA gene was targeted with the primer set 515f-806r (Caporaso et al. 2010), and the fungal internal transcribed spacer region was targeted with primers ITS1f and ITS2 (Gardes and Bruns 1993). PCR amplifications were performed with two PCR reactions. PCR reactions contained $3 \mu$ of normalized sample from the qPCR reaction, $0.48 \mu \mathrm{l}$ of nuclease-free water, $1.2 \mu \mathrm{l}$ of 5 times concentrated KAPA HiFi buffer (KAPA Biosystems, Woburn, MA), $0.18 \mu \mathrm{l}$ of 10 mM dNTPs (KAPA Biosystems, Woburn, MA), $0.3 \mu$ of DMSO (Fisher Scientific, Waltham, MA), $0.12 \mu 1$ of ROX (25 $\mu \mathrm{M})$ (Life Technologies, Carlsbad, CA), $0.003 \mu$ of 1,000 times SYBR Green, $0.12 \mu$ l of KAPA HiFidelity Hot Start polymerase (KAPA Biosystems, Woburn, MA), and $0.3 \mu 1$ of forward and reverse 
primers. Cycling condition for fungal and bacterial samples was $95^{\circ} \mathrm{C}$ for $5 \mathrm{~min}$, then 25 cycles of $20 \mathrm{sec}$ at $98^{\circ} \mathrm{C}, 15 \mathrm{sec}$ at $55^{\circ} \mathrm{C}$, and $1 \mathrm{~min}$ at $72^{\circ} \mathrm{C}$. Finally, samples spent $5 \mathrm{~min}$ at $72^{\circ} \mathrm{C}$ and were held at $4^{\circ} \mathrm{C}$. An Illumina Miseq 600 cycle v3 sequencing kit (Illumina, San Diego, CA, USA) was used to sequence the samples at the University of Minnesota Genomics Center.

\section{Taxonomic assignments of ASVs}

Quantitative Insights Into Microbial Ecology 2 (QIIME2) (version 2019.7; Bolyen et al. 2019) was used for quality control (i.e. removing unnecessary and low-quality base pairs) and some analysis. Prior to analysis, the primer sequences were removed using cutadapt (Version 2.7, Martin 2011), and the forward and reverse reads were joined using the tool VSEARCH (version 2.14.1, Rognes 2016). Reads with a Phred (Ewing and Green 1998) quality of <20 were removed (base call accuracy of at least 99\%). Deblur was used for quality control and to denoise the sequences by trimming off the low-quality bases (Amir et al. 2017). To correct for sampling depth differences, ITS1 (fungal DNA) samples were rarefied to 23,832 sequence reads and 16S (bacterial DNA) samples were rarefied to 101,222 sequence reads for downstream analyses. The Silva classifier (version r132; Quast et al. 2013) was a reference for the taxonomic analysis of bacterial sequences and UNITE (version 8.0, Nilsson et al. 2018) was used as the classifier for fungal (ITS) sequences. Archaeal sequences were excluded from the analysis.

\section{Statistical analyses}

The R Statistical program 3.6.2 (R Development Core Team, 2020) was primarily used to conduct statistical tests. Shannon's diversity index, generated in QIIME2 using code $p$ metric:Shannon, and observed ASVs (richness) were used as response variables along with ASV 
count data to the taxonomic level of genus. Treatment-related explanatory variables included presence or absence of a history of imidacloprid treatments (treatment history) and mean diameter at breast height $(\mathrm{DBH})$ of treated trees within the plots $(\mathrm{DBH})($ Table 1$)$. We included $\mathrm{DBH}$ as a candidate predictor because it is positively correlated with amount of imidacloprid applied to the plot. Concentration of imidacloprid detected in the soil was not used as a predictor candidate due to low recovery rates and presence of high leverage observations. Soil $\mathrm{pH}$ (converted to $\mathrm{H}+$ concentration for analyses), soil moisture, and soil texture were non-treatmentrelated explanatory environmental variables used to determine the influences of the environment and possible additive effects of non-focal variables on treatment-related variables. Interactions between soil $\mathrm{pH}$ and treatment-related variables were included in candidate models.

To determine the effects of imidacloprid on the bacterial and fungal communities, linear mixed models (LMMs) (Venables and Ripley 2002) were used. These models were created using package lme4 (Bates et al. 2015) with function lmer. Akaike's information criterion corrected for small sample sizes (AICc) was used to select the most supported models and was calculated using AICcmodavg (Mazerolle 2019). Continuous explanatory variables were standardized prior to analysis (mean $=0, \mathrm{SD}=1$ ). This was performed using the decostand function in the vegan package in R (Oksanen et al. 2019). Models that had a lower AICc score than the null model ( 1) were further analyzed by considering the beta coefficient estimates, $85 \%$ confidence intervals (Arnold 2010), and the pseudo $\mathrm{R}^{2}$ for GLMMs marginal values (Nakagawa and Schielzeth 2013, Johnson 2014, Nakagawa et al. 2017). These were used to determine if the model was supported and how influential the fixed variables were on the response variables.

Redundancy analyses (RDAs) were used to determine which groups were most correlated within fungal and bacterial groups (genera or lowest available taxa) using the vegan package in 
R. The response variables were Hellinger transformed to put less weight on rare species and response variables occurring in less than $10 \%$ of sites $(<2$ sites) were removed (McCune and Grace 2002). The RDA was performed using a covariance matrix. RDAs were made with the fungal and bacterial ASV groups as the response variables and treatment as the explanatory variable. To determine the support of the RDAs a global permutation test was performed, and the adjusted $\mathrm{R}^{2}$ value was retrieved from each ordination. The species scores were extracted from each of the four RDAs and used to determine groups most influenced by the treatment-related explanatory variable, treatment history. ASVs with a species score of $\geq 0.095$ or $\leq-0.095$ were identified as being correlated with treatment history.

\section{Results}

\section{Imidacloprid concentration and soil variables}

Imidacloprid was detected in 4 of the 9 plots with imidacloprid treatments. No imidacloprid was detected in the 9 control plots. The concentrations ranged from 20.88 to 0.64

$\mathrm{ng} / \mathrm{g}$ dry soil and the average was $8.64 \mathrm{ng} / \mathrm{g}$ dry soil (Table 1$)$. The soil moisture $\left(\mathrm{cm}^{3} \mathrm{H}_{2} \mathrm{O} / \mathrm{cm}^{3}\right.$ soil) had a range of 7.2-26.9 $\mathrm{cm}^{3} \mathrm{H}_{2} \mathrm{O} / \mathrm{cm}^{3}$ soil for control plots $(14.8 \pm 1.2 \mathrm{SD})$ and $7.2-26.9$ for treated plots $(14.6 \pm 2.0 \mathrm{SD})$. Soil $\mathrm{pH}$ ranged $3.72-4.98(4.19 \pm 0.14 \mathrm{SD})$ for control plots and $3.76-5.00(4.17 \pm 0.14)$ for treated plots. Because of the heterogeneity of soil $\mathrm{pH}$, the range of each $20 \mathrm{~m}^{2}$ plot is shown in Table 2.

\section{Community composition}

There were 1,270,417 and 1,424,324 high-quality ITS 1 and high-quality $16 \mathrm{~S}$ sequences, respectively. The sequences were classified into 428,976 fungal ASVs that were classified into 
603 groups and 457,330 bacterial ASVs that were classified into 1117 groups. The bacterial communities were dominated by the phyla Proteobacteria (32.7\%), Acidobacteria $(25.5 \%)$, and Actinobacteria (12.5\%). The most common genera were Acidothermus (5.6\%) and an unidentified Acidobacteria (4.2\%). None of the bacterial phyla or classes were significantly different between control and treated plots. The fungal community was mostly comprised of the phyla Ascomycota (46.3\%) and Basidiomycota (41.8\%) followed by the phylum Mortierellomycota (5.7\%). The most common genera were Archaeorhizomyces (14.0\%) and Russula (12.2\%).

\section{Community response to imidacloprid applications}

For bacterial diversity and richness, $\mathrm{pH}$, treatment $+\mathrm{pH}, \mathrm{DBH}+\mathrm{pH}$, and treatment $\mathrm{x} \mathrm{pH}$ models were more supported than the null models, with treatment $+\mathrm{pH}$ being the most supported treatment-related model in both model selections (Table 3). For treatment $+\mathrm{pH}$, bacterial diversity and richness were positively associated with treated plots. For $\mathrm{DBH}+\mathrm{pH}$, bacterial diversity and richness were negatively and positively associated with $\mathrm{DBH}$, respectively. The treatment $\times \mathrm{pH}$ model estimated that bacterial diversity and richness were more strongly associated with treated sites at high $\mathrm{pH}$. Bacterial treatment variable CIs overlapped 0 for all models except diversity DBH (Table 4), suggesting that $\mathrm{pH}$ was responsible for most of the explanatory power. For the fungal community, the null model was the most supported model for both diversity and richness (Table 3). 


\section{ASV response}

RDAs were not significant for bacterial ASVs (treatment [ $p$-value $=0.988$, adj. $R^{2}=-$ 0.022]) or fungal ASVs (treatment [ $\mathrm{p}$-value $=0.659$, adj. $\left.\mathrm{R}^{2}=-0.005\right]$ ). Based on the extracted species scores there were two bacterial ASV groups positively correlated with treatment and three that were negatively correlated. There were seven fungal ASV groups positively correlated with treatment and six that were negatively correlated (Table 5).

\section{Discussion}

Bacterial and fungal communities in this study did not have an observed response to imidacloprid applications. Based on Shannon's diversity index and observed ASVs representing richness there were no significant differences when considering DBH of treated trees, or whether there was a history of treatments on or near the plots. Previous studies that explored the effects of imidacloprid applied at the field recommended rate found that the fungal and bacterial communities were initially affected but recovered within a few months (Cycoń et al. 2013, Mahapatra et al. 2017). Another study that measured bacterial and fungal communities in wheat fields throughout a growing season found that the communities were affected after the initial application but fully recovered by the end of the growing season (Li et al. 2018). This study was different, as it was in a forest setting and application of imidacloprid requires concentrated injections into the soil or tree rather than an even spray application or seed treatments used in agricultural settings. Our study also focused on long-term effects ( $\geq 1$ year since application) of imidacloprid applications rather than within a few days, months, or through a growing season. Previous studies concluded that fungal and bacterial communities were affected initially but 
generally recovered over time, while our study showed that the soil bacterial and fungal communities were not affected by applications over a long period (2-8 years after applications). Crayton et al. (2020) used the same study area and reported bioaccumulation of imidacloprid in aquatic salamanders and benthic macroinvertebrates, as well as a decrease in salamander body condition and an increase in salamander corticosterone levels in relation to imidacloprid concentrations. Though this study's findings indicate that imidacloprid did not strongly impact the overall fungal and bacterial communities, Crayton et al. (2020) indicates that imidacloprid does have long-term non-target effects when considering other aspects of the forest community.

Bacterial and fungal diversity and richness were not strongly influenced by treatmentrelated variables. Notably, the bacterial community's richness and Shannon's diversity index decreased with lower $\mathrm{pH}$. Bacterial sensitivity to $\mathrm{pH}$ has been known to be the most influential environmental factor to bacteria. Fungi are not as sensitive and tend to be more tolerant of low pH, which is consistent with this study (Fierer and Jackson 2006, Rousk et al. 2010). Soil pH is also known to be heterogeneous and varies by as much as one unit within $1 \mathrm{~m}^{2}$ of sampling (Jackson and Caldwell 1993) making it difficult to accurately account for the variation. A range of the soil $\mathrm{pH}$ collected throughout 2018 is available (Table 2) to have a better understanding of the possible range within the $20-\mathrm{m}^{2}$ plots.

Acidibacillus was the bacterial genus most positively correlated treatment sites. This genus is an iron-oxidizing obligate heterotroph (Holand et al. 2015, Holand et al. 2016). An uncultured Fibrobacteraceae was most negatively correlated with treatment sites. This family is known for being found in the guts of mammals and termites (Hongoh et al. 2006, Ozbayram et al. 2018). 
Laccaria was the fungal genus most positively correlated with treated sites and has been associated with hemlock stands (Baird et al. 2014). Laccaria species are ectomycorrhizal fungi (Martin and Selosse 2008). Hirsutella was the fungal genus most negatively correlated with treated sites. It is a genus of insect, mite, and nematode pathogenic fungi (Bałazy et al. 2008).

In conclusion, based on the bacterial and fungal community trends, imidacloprid applications to hemlock stands did not have strong long-term effects. Individual taxa may be affected by treatments based on the 4/9 (bacteria/fungi) ASV groups positively influenced by treatment and the 6/7 ASV groups negatively influenced. Larger sample sizes and sampling throughout the year should be considered for future studies to build upon current knowledge. 


\section{Acknowledgments}

I thank Lenza Paul, Fabiola Clermont, Matthew DeSaix, Jaewon Kim, Sarah Stone, Kari Kindelberger, and Andrew McCloskey for field sampling and sample preparation. I thank Fumin Wang for help with Program R coding. I also thank Vicki Kondo for her helpful comments and suggestions for this thesis chapter. This study was supported by the National Park Service (P12AC31164).

\section{Literature Cited}

Agerer, R. Fungal relationships and structural identity of their ectomycorrhizae. Mycol Prog 2006; 5(2): 67-107.

Amir, A., McDonald, D., Navas-Molina, J.A., Kopylova, E., Morton, J.T., Xu, Z.Z., Kightley, E.P., Thompson, L.R., Hyde, E.R., Gonzalez, A. and Knight, R. Deblur rapidly resolves single-nucleotide community sequence patterns. mSystems 2017; 2(2): e00191-16.

Anderson, M.J. Permutational multivariate analysis of variance (PERMANOVA). Wiley statsref: statistics reference online $2014 ; 1-15$.

Arnold, T.W. Uninformative parameters and model selection using Akaike's Information Criterion. J Wildl Manag 2010; 74(6): 1175-1178.

Baird, R., Stokes, C.E., Wood-Jones, A., Alexander, M., Watson, C., Taylor, G., Johnson, K., Remaley, T., and Diehl, S. Fleshy saprobic and ectomycorrhizal fungal communities associated with healthy and declining eastern hemlock stands in Great Smoky Mountains National Park. Southeastern Naturalist 2014 13(6): 192-218. 
Bałazy, S., Wrzosek, M., Sosnowska, D., Tkaczuk, C., and Muszewska, A. Laboratory trials to infect insects and nematodes by some acaropathogenic Hirsutella strains (Mycota: Clavicipitaceous anamorphs). J Invert Pathol 2008; 97(2): 103-113.

Barros, N., Gomez-Orellana, I., Feijóo, S., and Balsa, R. The effect of soil moisture on soil microbial activity studied by microcalorimetry. Thermochimica Acta 1995; 249: 161-168.

Baskaran, S., Kookana, R.S., and Naidu, R. Degradation of bifenthrin, chlorpyrifos and imidacloprid in soil and bedding materials at termiticidal application rates. Pest Sci 1999; 55(12): 1222-1228.

Becraft, E.D., Woyke, T., Jarett, J., Ivanova, N., Godoy-Vitorino, F., Poulton, N., Brown, J.M., Brown, J., Lau, M.C.Y., Onstott, T. and Eisen, J.A. Rokubacteria: Genomic giants among the uncultured bacterial phyla. Front Microbiol 2017; 8: 2264.

Benton, E.P., Grant, J.F., Webster, R.J., Cowles, R.S., Lagalante, A.F., Saxton, A.M., Nichols, R.J. and Coots, C.I. Hemlock woolly adelgid (Hemiptera: Adelgidae) abundance and canopy health numerous years after imidacloprid basal drench treatments: implications for management programs. Forest Entomol 2016; 109: 2125-2136.

Bolyen, E., Rideout, J.R., Dillon, M.R., Bokulich, N.A., Abnet, C.C., Al-Ghalith, G.A., Alexander, H., Alm, E.J., Arumugam, M., Asnicar, F. and Bai, Y. et. al. Reproducible, interactive, scalable and extensible microbiome data science using QIIME 2. Nat Biotechnol 2019; 37: 852-857.

Caporaso, J.G., Kuczynski, J., Stombaugh, J., Bittinger, K., Bushman, F.D., Costello, E.K., Fierer, N., Pena, A.G., Goodrich, J.K., Gordon, J.I. and Huttley, G.A., et al. QIIME allows analysis of high-throughput community sequencing data. Nat Methods 2010; $7: 335-6$. 
Christensen, M., Frisvad, J.C., Tuthill, D.E. Penicillium species diversity in soil and some taxonomic and ecological notes. Integration of modern taxonomic methods for Penicillium and Aspergillus. Amsterdam: Harwood Acad. Publishers. 2000; 309-322

Crayton, S. M., Wood, P. B., Brown, D. J., Millikin, A. R., McManus, T. J., Simpson, T. J., Ku, K.M., and Park Y.-L. Bioaccumulation of the pesticide imidacloprid in stream organisms and sublethal effects on salamanders. Global Ecol Conserv 2020; 24: e01292.

Cycoń, M., and Piotrowska-Seget, Z. Biochemical and microbial soil functioning after application of the insecticide imidacloprid. J Environ Sci 2015a; 27: 147-158.

Cycoń, M., and Piotrowska-Seget, Z. Community structure of ammonia-oxidizing archaea and ammonia-oxidizing bacteria in soil treated with the insecticide imidacloprid. BioMed Res Int 2015b; 582938.

Cycoń, M., Markowicz, A., Borymski, S., Wójcik, M. and Piotrowska-Seget, Z. Imidacloprid induces changes in the structure, genetic diversity and catabolic activity of soil microbial communities. J Environ Manag 2013; 131: 55-65.

Elbert, A., Becker, B., Hartwig, J., and C. Erdelen. Imidacloprid-a new systemic insecticide. Pflanzenschutz-Nachrichten Bayer (Germany, FR) 1991.

Ewing, B., and Green, P. (1998). Base-calling of automated sequencer traces using phred. II. Error probabilities. Genome Res 1998; 8(3): 186-194.

Fell, J. W. Sakaguchia Y. Yamada, Maeda \& Mikata. In The Yeasts 2011: 1541-1544. Elsevier 1994.

Fierer, N., and R.B. Jackson. The diversity and biogeography of soil bacterial communities. PNAS 2006; 103(3): 626-631. 
Gardes, M., and Bruns, T. ITS primers with enhanced specificity for basidiomycetes application to the identification of mycorrhizae and rusts. Mol Ecol 1993; 2: 113-8.

Graebing, P., and J.S. Chib, J. S. Soil photolysis in a moisture-and temperature-controlled environment. 2. Insecticides. J Agr Food Chem 2004; 52(9): 2606-2614.

Hermans, S.M., Buckley, H.L., Case, B.S., Curran-Cournane, F., Taylor, M. and Lear, G. Bacteria as emerging indicators of soil condition. Appl Environ Microbiol 2017; 83(1): e02826-16.

Hladik, M. L., and Calhoun, D.L. Analysis of the herbicide diuron, three diuron degradates, and six neonicotinoid insecticides in water-method details and application to two Georgia streams. Scientific Investigations Report 2012; 5206.

Hobara, S., Osono, T., Hirose, D., Noro, K., Hirota, M. and Benner, R. The roles of microorganisms in litter decomposition and soil formation. Biogeochemistry 2014; 118(13): 471-486.

Holanda, R., Hedrich, S., Falagán, C., Ňancucheo, I., DallAgnol, H., Grail, B. M., and Johnson, D.B. Characteristics of Acidibacillus spp.: a novel genus of acidophilic iron-oxidising Firmicutes. In Advanced Materials Research 2015; 1130: 36-39. Trans Tech Publications Ltd.

Holanda, R., Hedrich, S., Ňancucheo, I., Oliveira, G., Grail, B. M., and Johnson, D.B. Isolation and characterisation of mineral-oxidising "Acidibacillus" spp. from mine sites and geothermal environments in different global locations. Res Microbiol 2016; 167(7): 613623. 
Hongoh, Y. and Deevong, P. and Hattori, S. and Inoue, T. and Noda, S. and Noparatnaraporn, N. and Kudo, T. and Ohkuma, M. Phylogenetic diversity, localization, and cell morphologies of members of the candidate phylum TG3 and a subphylum in the phylum Fibrobacteres, recently discovered bacterial groups dominant in termite guts. Appl Environ Microb 2006; 72(10): 6780-6788.

Jackson, R.B., and Caldwell, M.M. Geostatistical patterns of soil heterogeneity around individual perennial plants. J Ecol 1993; 683-692.

Ji, M., Greening, C., Vanwonterghem, I., Carere, C.R., Bay, S.K., Steen, J.A., Montgomery, K., Lines, T., Beardall, J., Van Dorst, J., Snape, I., Stott, M.B., Hugenholtz, P., and Ferrari, B.C. Atmospheric trace gases support primary production in antarctic desert surface soil. Nature 2017; 552: 400-403.

Johnsen, K., Jacobsen, C. S., Torsvik, V., and Sørensen, J. Pesticide effects on bacterial diversity in agricultural soils-a review. Biol Fert Soils 2001; 33(6): 443-453.

Johnson, P.C.D. Extension of Nakagawa \& Schielzeth’s R_GLMM² to random slopes models. Methods Eco Evol 2014; 5: 44-946

Kowalchuk, G. A., and Stephen, J. R. Ammonia-oxidizing bacteria: a model for molecular microbial ecology. Annu Rev Microbiol 2001; 55(1): 485-529.

Kulichevskaya, I.S., Ivanova, A.O., Belova, S.E., Baulina, O.I., Bodelier, P.L., Rijpstra, W.I.C., Damasté, J.S.S., Zavarzin, G.A., and Dedysh, S.N. Schlesneria paludicola gen. nov., sp. nov., the first acidophilic member of the order Planctomycetales, from Sphagnumdominated boreal wetlands. Int J Syst Evol Micr 2007; 57(11): 2680-2687. 
Li, Y., An, J., Dang, Z., Lv, H., Pan, W. and Gao, Z. Treating wheat seeds with neonicotinoid insecticides does not harm the rhizosphere microbial community. PLoS One 2018; $13(12)$.

Liu, M. Y., and Casida, J.E. High affinity binding of $[3 \mathrm{H}]$ imidacloprid in the insect acetylcholine receptor. Pestic Biochem Physiol 1993; 46(1): 40-46.

Mahapatra, B., Adak, T., Patil, N.K., Gowda, G.B., Jambhulkar, N.N., Yadav, M.K., Panneerselvam, P., Kumar, U., Munda, S. and Jena, M. Imidacloprid application changes microbial dynamics and enzymes in rice soil. Ecotoxicol Environ Safety 2017; 144: 123130.

Martin, F., and Selosse, M. A. The Laccaria genome: a symbiont blueprint decoded. New Phytol 2008; 296-310.

Martin, M. Cutadapt removes adapter sequences from high-throughput sequencing reads. EMBnet J 2011; 17(1): 10-12.

Martınez-Toledo, M.V., Salmeron, V., Rodelas, B., Pozo, C., and Gonzalez-Lopez, J. Effects of the fungicide Captan on some functional groups of soil microflora. Appl Soil Ecol 1998; 7(3): $245-255$.

Mazerolle, Marc J. AICcmodavg: Model selection and multimodel inference based on (Q)AIC(c). R package 2019; version 2.2-2. https://cran.rproject.org/package=AICcmodavg.

McClure, M.S., S.M. Salom, and K.S. Shields. Hemlock woolly adelgid. U.S. Department of Agriculture, Forest Service, Forest Health Technology Enterprise Team 2001; Morgantown, West Virginia. 
McCune, B., and Grace, J.B. Analysis of ecological communities. In: MjM Software Design. Gleneden Beach, Oregon. 2002.

Nagahama, T., Hamamoto, M., Nakase, T. and Horikoshi, K. Rhodotorula lamellibrachii sp. nov., a new yeast species from a tubeworm collected at the deep-sea floor in Sagami Bay and its phylogenetic analysis. Antonie van Leeuwenhoek 2001; 80: 317-333.

Nakagawa, S., and Schielzeth H, A general and simple method for obtaining $\mathrm{R}^{2}$ from generalized linear mixed-effects models. Methods Ecol Evol 2013; 4(2): 133-142.

Nakagawa, S., Johnson, P.C.D., and Schielzeth, H. The coefficient of determination $\mathrm{R}^{2}$ and intraclass correlation coefficient from generalized linear mixed-effects models revisited and expanded. J R Soc Interface 2017 14: 20170213.

National Center for Environmental Information. WV US US1WVNC0005 station 2020.

Nilsson R.H., Larsson, K.H., Taylor A.F.S., Bengtsson-Palme J., Jeppesen T.S., Schigel D., Kennedy P., Picard K., Glöckner F.O., Tedersoo L. Saar, I., Kõljalg, U., and Abarenkov, K. The UNITE database for molecular identification of fungi: handling dark taxa and parallel taxonomic classifications. Nucl Acids Res 2018; 47: D259-D264.

Nogales, B., Moore, E.R., Llobet-Brossa, E., Rossello-Mora, R., Amann, R., and Timmis, K.N. Combined use of $16 \mathrm{~S}$ ribosomal DNA and 16S rRNA to study the bacterial community of polychlorinated biphenyl-polluted soil. Appl Environ Microbiol 2001; 67: 1874-1884.

Noordeloos, M.E. Entoloma sl (Vol. 1). Libreria editrice Giovanna Biella. 1992

Oksanen, J.F., Blanchet, G Friendly M., Kindt R., Legendre P., McGlinn D., Minchin P.R., O’Hara R.B., Simpson G.L., Solymos P., Stevens M.H.H., Szoecs E., and Wagner H. vegan: Community Ecology Package. R package 2019; version 2.5-6. https:/CRAN.Rproject.org/package=vegan 
Ozbayram, E. G., Ince, O., Ince, B., Harms, H., and Kleinsteuber, S. Comparison of rumen and manure microbiomes and implications for the inoculation of anaerobic digesters. Microorganisms 2018; 6(1): 15.

Price M.N., P.S. Dehal, and A.P. Arkin. FastTree 2 - Approximately Maximum-Likelihood Trees for Large Alignments. PLoS One 2010; 5(3): e9490.

Prosser, J.I., Head, I.M., and Stein, L.Y. The family Nitrosomonadaceae. In: The Prokaryotes: Alphaproteobacteria and Betaproteobacteria. Springer Berlin/Heidelberg 2014; 901-918.

Quast C., E. Pruesse, P. Yilmaz, J. Gerken, J., Schweer, T., Yarza, P., Peplies, J. and Glöckner, F.O. The SILVA ribosomal RNA gene database project: improved data processing and web-based tools. Nucl. Acids Res 2013; 41: D590-D596.

Reichenbach H. The ecology of the myxobacteria. Environ. Microbiol. 1999;1:15-21.

Rillig, M.C., and Mummey, D. L. Mycorrhizas and soil structure. New Phytol 2006; 171(1): 4153.

Rognes, T., Flouri, T., Nichols, B., Quince, C., and Mahé, F. VSEARCH: a versatile open source tool for metagenomics. PeerJ, 2016; 4: e2584.

Roody W.C. Mushrooms of West Virginia and the Central Appalachians. Lexington: University Press of Kentucky 2003; 231.

Rosenberg E. (2014) The Prokaryotes. Springer, Berlin, Heidelberg. 2014; 757-758

Rousk, J., Bååth, E., Brookes, P. C., Lauber, C. L., Lozupone, C., Caporaso, J. G., Knight, R., and N. Fierer. Soil bacterial and fungal communities across a $\mathrm{pH}$ gradient in an arable soil. ISME J 2010; 4(10): 1340-1351. 
Sanford, R.A., Cole, J.R., and Tiedje, J.M. Characterization and description of Anaeromyxobacter dehalogenans gen. nov., sp. nov., an aryl-halorespiring facultative anaerobic myxobacterium. Appl Environ Microbiol 2002; 68(2): 893-900.

Sarkar, M.A., Roy, S., Kole, R. K., and Chowdhury, A. Persistence and metabolism of imidacloprid in different soils of West Bengal. Pest Manag Sci 2001; 57(7): 598-602.

Seymour, N. Impacts of pesticides and fertilisers on soil biota. In: Soil Biology - Soil Health Conference, Condamine Catchment Management Association Inc 4th - 5th May 2005; RSL, Dalby.

Sheremet, A., Jones, G.M., Jarett, J., Bowers, R.M., Bedard, I., Culham, C., Eleo-Fadrosh, E., Ivanova, N., Malmstrom, R., Grasgy, S., Woyke, T., and Dunfield, P.F. Ecological and genomic analyses of candidate phylum WPS-2 bacteria in an unvegetated soil. Environ Microbiol 2020; 22(8): 3143-3157.

Shi, L., Dossa, G. G., Paudel, E., Zang, H., Xu, J. and Harrison, R.D. Changes in fungal communities across a forest disturbance gradient. Appl Environ Microbiol 2019; 85(12): e00080-19.

Silcox, C. Using imidacloprid to control hemlock woolly adelgid. Proceedings Hemlock Woolly Adelgid in the Eastern United States. NJ Agricultural Experiment Station, New Brunswick, New Jersey 2002; 280-287.

Singh, J., and Singh, D.K. Bacterial, azotobacter, actinomycetes, and fungal population in soil after diazinon, imidacloprid, and lindane treatments in groundnut (Arachis hypogaea L.) fields. J Environ Sci Heal B 2005; 40(5): 785-800. 
Steward, B., and Horner, T.A. Control of hemlock woolly adelgid with soil injections using Merit 2F (imidacloprid) and Metasystox-R2 (oxydemeton-methyl), 1993. Arthrop Manag Tests 1994; 19(1): 348-348.

Strickler, L. Hemlock woolly adelgid control project annual report 2012: New River Gorge National River, Gauley River National Recreation Area, and Bluestone National Scenic River. Natural Resources Report NPS/NERI/NRR- 2014/818. National Park Service, Fort Collins, CO.

Thomson, B.C., Tisserant, E., Plassart, P., Uroz, S., Griffiths, R.I., Hannula, S.E., Buée, M., Mougel, C., Ranjard, L., Van Veen, J.A., Martin, F., Bailey, M.J., and Lemanceau P. Soil conditions and land use intensification effects on soil microbial communities across a range of European field sites. Soil Biol Biochem 2015; 88: 403-413.

Tiedje, J.M. Ecology of denitrification and dissimilatory nitrate reduction to ammonium. Biol Anaer Microorg 1988; 717: 179-244.

Trappe J.M. Fungus associates of ectotrophic mycorrhizae. Bot Rev 1962; 28 (4): 538-606. Van Der Heijden, M.G., Bardgett, R.D., and Van Straalen, N.M. The unseen majority: soil microbes as drivers of plant diversity and productivity in terrestrial ecosystems. Ecol Lett 2008; 11(3): 296-310.

Van Veen, J.A., and Kuikman, P. J. Soil structural aspects of decomposition of organic matter by micro-organisms. Biogeochemistry 1990; 11(3): 213-233.

Wang, M.C., Liu, Y.H., Wang, Q., Gong, M., Hua, X. M., Pang, Y. J., et al. Impacts of methamidophos on the biochemical, catabolic, and genetic characteristics of soil microbial communities. Soil Biol Biochem 2008; 40(3): 778-788. 
Yoshida, N., Son, J.A., Matsushita, N., Iwamoto, K., and Hogetsu, T. Fine-scale distribution of ectomycorrhizal fungi colonizing Tsuga diversifolia seedlings growing on rocks in a subalpine Abies veitchii forest. Mycorrhiza 2014; 24(4): 247-257.

Zhang, P., Ren, C., Sun, H., and Min., L. Sorption, desorption and degradation of neonicotinoids in four agricultural soils and their effects on soil microorganisms. Sci Total Environ 2018; 615: 59-69. 
Figures and Tables

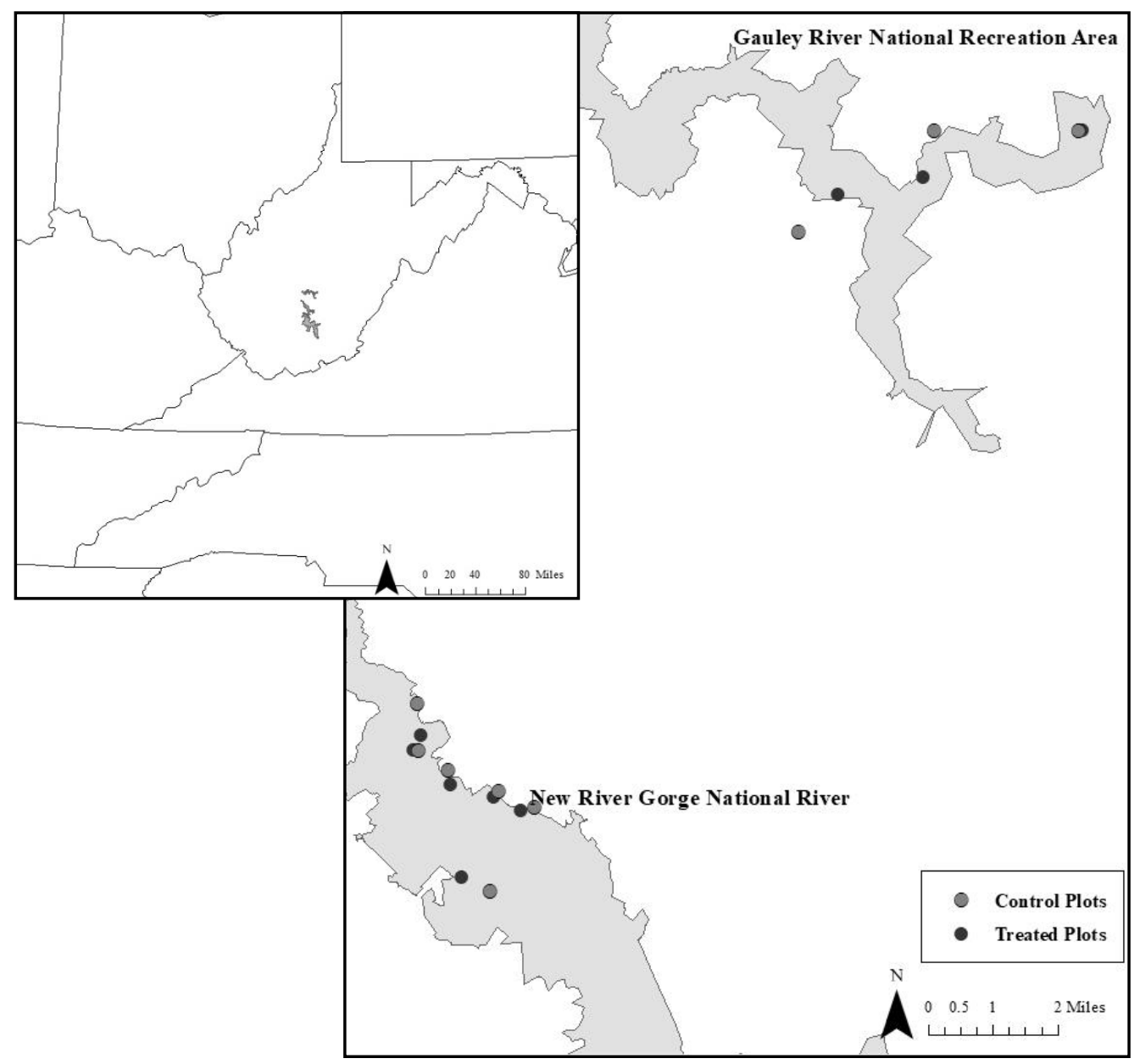

Figure 1: A total of 9 study sites, consisting of paired treated and control plots, were located in the Gauley River National Recreation Area (GARI) and New River Gorge National River (NERI). The sites were used to determine the long-term effects of imidacloprid applications on soil bacteria and fungi in hemlock stands. 
Table 1: The 9 treated plots sampled located in the Gauley River National Recreation Area (GARI) and New River Gorge National River (NERI) in southern West Virginia had varying imidacloprid treatment backgrounds. The years since last application (years post application) in treated plots ranged from 2-8 years. Burnwood 2 and Summersville Dam 2 were not treated within the plots, but trees surrounding the plot were treated. Plots have a range for years since last treatment because they were sampled in 2018 and 2019. Imidacloprid concentration refers to soil concentration.

\begin{tabular}{cccc}
\hline Site & $\begin{array}{c}\text { Years post } \\
\text { application }\end{array}$ & DBH & $\begin{array}{c}\text { Imidacloprid } \\
\text { concentration } \\
\text { (ng/g dry soil) }\end{array}$ \\
\hline Summersville Dam 2 & N/A & 0 & 0.64 \\
Carnifex Ferry & $2-3$ & 243.1 & 6.48 \\
Elliott Cutoff & $4-5$ & 103.6 & 20.88 \\
Burnwood 2 & N/A & 0 & 0 \\
Bridge Buttress & $5-6$ & 96.0 & 6.55 \\
Fern Buttress & $2-3$ & 102.4 & 0 \\
Fern Creek 4 & $7-8$ & 319.5 & 0 \\
Nuttall & $5-6$ & 168.3 & 0 \\
Kaymoor 2 & $2-3$ & 67.3 & 0 \\
\hline
\end{tabular}


Table 2: Samples taken at the Gauley River National Recreation Area (GARI) and New River Gorge National River (NERI) in southern West Virginia were taken to determine the effects of imidacloprid on soil bacteria and fungi. The $\mathrm{pH}$ of the soil within each $20 \mathrm{~m}^{2}$ plot was taken 12 times throughout 2018. Soil pH is known to be heterogeneous, so the range of the plots is given to better understand the variation within each plot.

\begin{tabular}{ccc} 
Site & Treatment & Soil pH Range \\
\hline Summersville Dam 2 & Control & $4.60-5.40$ \\
& Treatment & $4.45-5.38$ \\
Carnifex Ferry & Control & $4.08-4.79$ \\
& Treatment & $3.15-4.22$ \\
Elliott Cutoff & Control & $3.62-4.03$ \\
& Treatment & $3.50-4.55$ \\
Burnwood 2 & Control & $3.12-4.11$ \\
& Treatment & $3.72-4.22$ \\
Bridge Buttress & Control & $3.64-4.40$ \\
& Treatment & $4.00-5.49$ \\
Fern Buttress & Control & $4.29-5.41$ \\
& Treatment & $3.56-4.43$ \\
Fern Creek 4 & Control & $4.28-4.72$ \\
& Treatment & $3.30-4.60$ \\
Nuttall & Control & $3.66-4.06$ \\
& Treatment & $3.87-4.19$ \\
Kaymoor 2 & Control & $3.56-4.54$ \\
& Treatment & $4.01-4.49$ \\
\hline
\end{tabular}


Table 3: Linear mixed models (LMMs) were used to determine the effects of imidacloprid on bacterial and fungal communities at the study sites located in the Gauley River National Recreation Area (GARI) and New River Gorge National River (NERI), and surrounding land in southern West Virginia. Akaike's Information Criterion corrected for small sample size (AICc) was used for model selection. Bacterial and fungal diversity and richness were the response variables. The treatment-related variables were mean diameter at breast height of treated trees within plots (DBH), and whether the plots had a history of being treated on not (Treatment). Soil $\mathrm{pH}$, moisture, and composition (Soil) were explanatory environmental variables, and the interaction between $\mathrm{pH}$ and treatmentrelated variables was included as candidate models. The null model $(\sim 1)$ was used to determine which models were possibly supported.

\begin{tabular}{|c|c|c|c|c|c|c|c|}
\hline \multirow{2}{*}{ Bacteria } & \multicolumn{3}{|c|}{ Diversity } & \multicolumn{4}{|c|}{ Richness } \\
\hline & $\mathrm{AICc}$ & $\Delta \mathrm{AICc}$ & AICc Wt. & & $\mathrm{AICc}$ & $\Delta \mathrm{AICc}$ & AICc Wt. \\
\hline $\mathrm{pH}$ & 51.17 & 0.000 & 0.766 & $\mathrm{pH}$ & 50.48 & 0.000 & 0.778 \\
\hline Treatment $+\mathrm{pH}$ & 54.68 & 3.509 & 0.132 & Treatment $+\mathrm{pH}$ & 54.12 & 3.648 & 0.126 \\
\hline $\mathrm{DBH}+\mathrm{pH}$ & 56.74 & 5.571 & 0.047 & $\mathrm{DBH}+\mathrm{pH}$ & 56.00 & 5.526 & 0.049 \\
\hline Treatment $* \mathrm{pH}$ & 58.70 & 7.530 & 0.018 & Treatment $* \mathrm{pH}$ & 58.14 & 7.665 & 0.017 \\
\hline Null & 58.85 & 7.681 & 0.016 & Null & 58.77 & 8.290 & 0.012 \\
\hline $\mathrm{DBH} * \mathrm{pH}$ & 61.55 & 10.387 & 0.004 & $\mathrm{DBH} * \mathrm{pH}$ & 60.58 & 10.102 & 0.005 \\
\hline Soil & 61.56 & 10.394 & 0.004 & Moisture & 60.76 & 10.282 & 0.005 \\
\hline Moisture & 61.59 & 10.426 & 0.004 & Soil & 61.52 & 11.042 & 0.003 \\
\hline Treatment & 61.75 & 10.580 & 0.004 & Treatment & 61.76 & 11.288 & 0.003 \\
\hline $\mathrm{DBH}$ & 63.12 & 11.958 & 0.002 & $\mathrm{DBH}$ & 63.14 & 12.667 & 0.001 \\
\hline Treatment + Moisture & 65.10 & 13.932 & 0.001 & Treatment + Soil & 65.13 & 14.655 & 0.001 \\
\hline Treatment + Soil & 65.83 & 14.663 & 0.001 & Treatment + Moisture & 65.18 & 14.703 & 0.000 \\
\hline $\mathrm{DBH}+$ Moisture & 66.50 & 15.330 & 0.000 & $\mathrm{DBH}+$ Soil & 66.41 & 15.937 & 0.000 \\
\hline DBH + Soil & 66.99 & 15.822 & 0.000 & $\mathrm{DBH}+$ Moisture & 66.46 & 15.987 & 0.000 \\
\hline
\end{tabular}


Table 3 Continued

\begin{tabular}{|c|c|c|c|c|c|c|c|}
\hline \multirow[b]{2}{*}{ Fungi } & \multicolumn{3}{|c|}{ Diversity } & \multicolumn{4}{|c|}{ Richness } \\
\hline & $\mathrm{AICc}$ & $\Delta \mathrm{AICc}$ & AICc Wt. & & $\mathrm{AICc}$ & $\Delta \mathrm{AICc}$ & $\mathrm{AICc} \mathrm{Wt}$ \\
\hline Null & 58.85 & 0.000 & 0.406 & Null & 57.70 & 0.000 & 0.366 \\
\hline Soil & 60.54 & 1.695 & 0.174 & Treatment & 58.95 & 1.246 & 0.196 \\
\hline Treatment & 61.53 & 2.680 & 0.106 & $\mathrm{pH}$ & 60.30 & 2.596 & 0.100 \\
\hline $\mathrm{pH}$ & 61.57 & 2.725 & 0.104 & $\mathrm{DBH}$ & 60.55 & 2.845 & 0.088 \\
\hline Moisture & 62.82 & 3.975 & 0.056 & Moisture & 61.24 & 3.541 & 0.062 \\
\hline $\mathrm{DBH}$ & 63.06 & 4.210 & 0.049 & Treatment $+\mathrm{pH}$ & 61.48 & 3.778 & 0.055 \\
\hline Treatment + Moisture & 63.82 & 4.967 & 0.034 & Soil & 61.69 & 3.983 & 0.050 \\
\hline Treatment $+\mathrm{pH}$ & 64.67 & 5.822 & 0.022 & $\mathrm{DBH}+\mathrm{pH}$ & 63.25 & 5.545 & 0.023 \\
\hline DBH + Moisture & 65.07 & 6.218 & 0.018 & Treatment + Moisture & 63.58 & 5.881 & 0.019 \\
\hline $\mathrm{DBH}+\mathrm{pH}$ & 66.31 & 7.458 & 0.010 & Treatment + Soil & 64.48 & 6.773 & 0.012 \\
\hline Treatment x pH & 66.67 & 7.817 & 0.008 & $\mathrm{DBH}+$ Moisture & 64.68 & 6.977 & 0.011 \\
\hline Treatment + Soil & 66.67 & 7.823 & 0.008 & DBH + Soil & 65.84 & 8.135 & 0.006 \\
\hline DBH + Soil & 68.23 & 9.386 & 0.004 & Treatment $* \mathrm{pH}$ & 66.13 & 8.423 & 0.005 \\
\hline DBH $x \mathrm{pH}$ & 71.01 & 12.163 & 0.001 & $\mathrm{DBH} * \mathrm{pH}$ & 66.98 & 9.275 & 0.004 \\
\hline
\end{tabular}


Table 4: Linear mixed models (LMM) were used to determine the effects of imidacloprid on bacterial and fungal communities in hemlock stands located in the Gauley River National Recreation Area (GARI) and New River Gorge National River (NERI), and surrounding land in southern West Virginia. Community richness and Shannon's diversity index (diversity) models with a lower AICc score than the null model $(\sim 1)$ and with a treatment-related variable were used to determine the impacts of imidacloprid applications on the bacterial and fungal communities, along with models with non-treatment-related environmental variables when they can be compared alongside the treatment-related variables. The $85 \%$ confidence intervals (CIs), coefficient $(\beta)$ estimates, and Pseudo $\mathrm{R}^{2}$ for GLMMs values were used to determine the model support. Treatment-related variables included plots with a treatment history vs. control plots (Treatment), and average diameter at breast height of trees treated within the plots (DBH). DBH was used because the amount of imidacloprid applied for hemlock woolly adelgid control is dependent on the DBH of the tree being treated.

\begin{tabular}{|c|c|c|c|c|}
\hline Models & $\beta$ & Lower CI & Upper CI & $\mathrm{R}^{2}$ \\
\hline \multicolumn{5}{|c|}{ Bacterial Diversity } \\
\hline Intercept & $-1.765 \mathrm{e}-15$ & -0.234 & 0.234 & \\
\hline $\mathrm{pH}$ & -0.729 & -0.996 & -0.487 & 0.514 \\
\hline Intercept & -0.147 & -0.469 & 0.177 & \\
\hline $\begin{array}{l}\text { Treatment } \\
\mathrm{pH}\end{array}$ & $\begin{array}{l}0.293 \\
-0.745\end{array}$ & $\begin{array}{l}-0.165 \\
-1.05\end{array}$ & $\begin{array}{l}0.750 \\
-0.506\end{array}$ & 0.522 \\
\hline Intercept & -1.765 e- 15 & -0.21633 & 0.216 & \\
\hline $\begin{array}{l}\mathrm{DBH} \\
\mathrm{pH}\end{array}$ & $\begin{array}{l}-0.0081 \\
-0.726\end{array}$ & $\begin{array}{l}-0.249 \\
-0.967\end{array}$ & $\begin{array}{l}-0.037 \\
-0.492\end{array}$ & 0.497 \\
\hline Intercept & -0.162 & -0.480 & 0.153 & \\
\hline Treatment & 0.292 & -0.147 & 0.721 & \\
\hline $\mathrm{pH}$ & -0.911 & -1.301 & -0.579 & \\
\hline Treatment:pH & 0.339 & -0.140 & 0.785 & 0.546 \\
\hline \multicolumn{5}{|c|}{ Bacterial Richness } \\
\hline Intercept & $-5.478 \mathrm{e}-16$ & -0.228 & 0.228 & \\
\hline $\mathrm{pH}$ & -0.740 & -0.975 & -0.505 & 0.533 \\
\hline Intercept & -0.134 & -0.450 & 0.183 & \\
\hline Treatment & 0.267 & -0.182 & 0.716 & \\
\hline $\mathrm{pH}$ & -0.753 & -0.984 & -0.522 & 0.536 \\
\hline Intercept & $-5.48 \mathrm{e}-16$ & -0.228 & 0.228 & \\
\hline DBH & 0.0518 & -0.183 & 0.287 & \\
\hline $\mathrm{pH}$ & -0.744 & -0.978 & -0.509 & 0.519 \\
\hline Intercept & -0.147 & -0.456 & 0.161 & \\
\hline Treatment & 0.263 & -0.172 & 0.695 & \\
\hline $\mathrm{pH}$ & -0.900 & -1.228 & -0.600 & \\
\hline Treatment:pH & 0.334 & -0.127 & 0.782 & 0.551 \\
\hline \multicolumn{5}{|c|}{$\begin{array}{l}\text { Fungal Diversity } \\
\text { N/A }\end{array}$} \\
\hline $\begin{array}{l}\text { Fungal Richne } \\
\text { N/A }\end{array}$ & & & & \\
\hline
\end{tabular}


Table 5: The bacterial and fungal taxa (genus or the lowest taxonomic level available) most correlated with imidacloprid applications in hemlock stands located in the Gauley River National Recreation Area (GARI) and New River Gorge National River (NERI), and surrounding land in southern West Virginia were determined. Species scores were extracted from redundancy analysis (RDA) with treatment history as the explanatory variable. Bacterial and fungal taxa were considered correlated with the treatment-related variables if their species scores were $\geq$ 0.095 or $\leq-0.095$. Negative scores indicate a negative correlation and species scores indicate a positive correlation. The overall abundance of the bacterial and fungal taxa was also included.

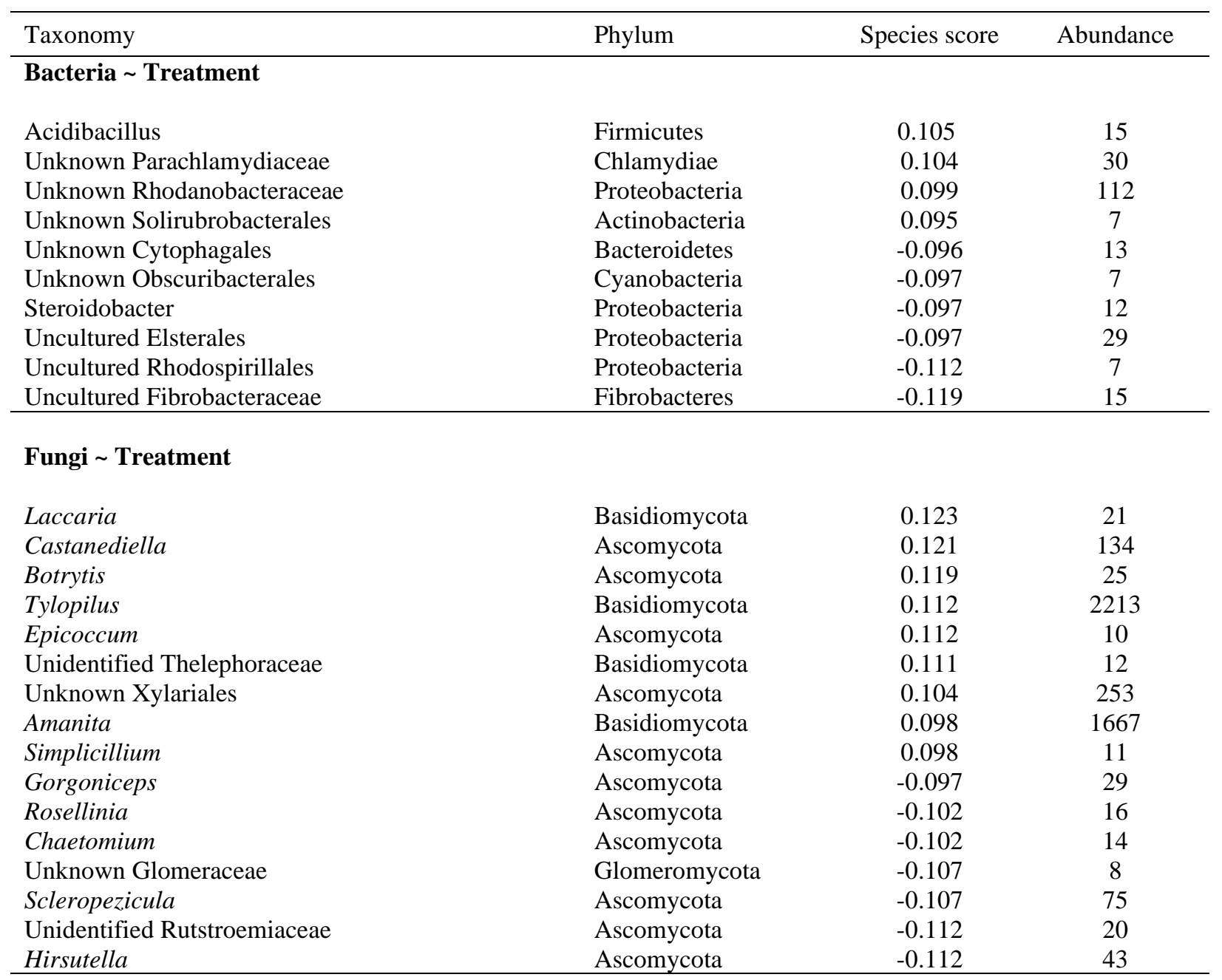




\section{Chapter 4: Study Conclusions}

This research aimed to determine the relationship between imidacloprid applications in hemlock stands and non-target soil organisms that may be affected by the applications over longterm exposure. This information could help forest managers better understand the impact of imidacloprid applications and adjust their practices based on their knowledge. The research objectives were (1) to determine the long-term effects of imidacloprid applications in hemlock stands on the soil collembolan community and (2) to determine the long-term effects of imidacloprid applications in hemlock stands on the soil fungal and bacterial communities.

In Chapter 2, the collembolan community's relationship to imidacloprid applications was analyzed. Collembolan community metrics (abundance, Shannon's diversity, and morphospecies richness) did not have models that were supported with strong explanatory power. Morphospecies richness for the collembolan trophic levels (i.e. euedaphic, hemiedaphic, and epedaphic) were also considered. Euedaphic and hemiedaphic collembolan abundance was influenced. Abundance was greater in treated plots when $\mathrm{pH}$ was lower and greater in control plots when $\mathrm{pH}$ was higher for epedaphic and hemiedaphic communities, and epedaphic abundance decreased as DBH of treated trees increased and pH was lower. Based on this study, euedaphic and hemiedaphic collembolans may be influenced by the long-term effects of imidacloprid applications when applied at the field recommended rate for HWA prevention in hemlock stands within this study area.

In Chapter 3, I did not find an overarching pattern to bacterial and fungal community trends and imidacloprid application. Bacterial and fungal community metrics (Shannon's diversity and richness of lowest available taxa) did not have models with strong explanatory 
power. The exception was low $\mathrm{pH}$ decreasing bacterial community richness and Shannon's diversity. Imidacloprid applications did not strongly affect bacterial and fungal communities in hemlock stands within this study site over the long term ( $\geq$ a year post application). Though the overall diversity of the communities were not strongly affected, individual taxa may be affected.

Euedaphic and hemiedaphic collembolan communities were affected by imidacloprid treatments while the soil bacteria and fungi were not strongly affected, though collembolans and bacterial were both influenced by soil $\mathrm{pH}$. The soil organisms in this study are closely linked, as collembolans are known for their influence on the microbial community through selective feeding and spore dispersal. Further research on the long-term effects of imidacloprid are needed to understand the long-term impacts of imidacloprid applications throughout the environment. Future studies should consider more replications over a longer period when determining the effects of collembolans, bacteria, and fungi to better understand the community trends. Future studies should also consider other organisms within the food web that could be impacted by imidacloprid applications. 